Prepared in cooperation with the Federal Emergency Management Agency

\title{
Analysis of Storm-Tide Impacts From Hurricane Sandy in New York
}

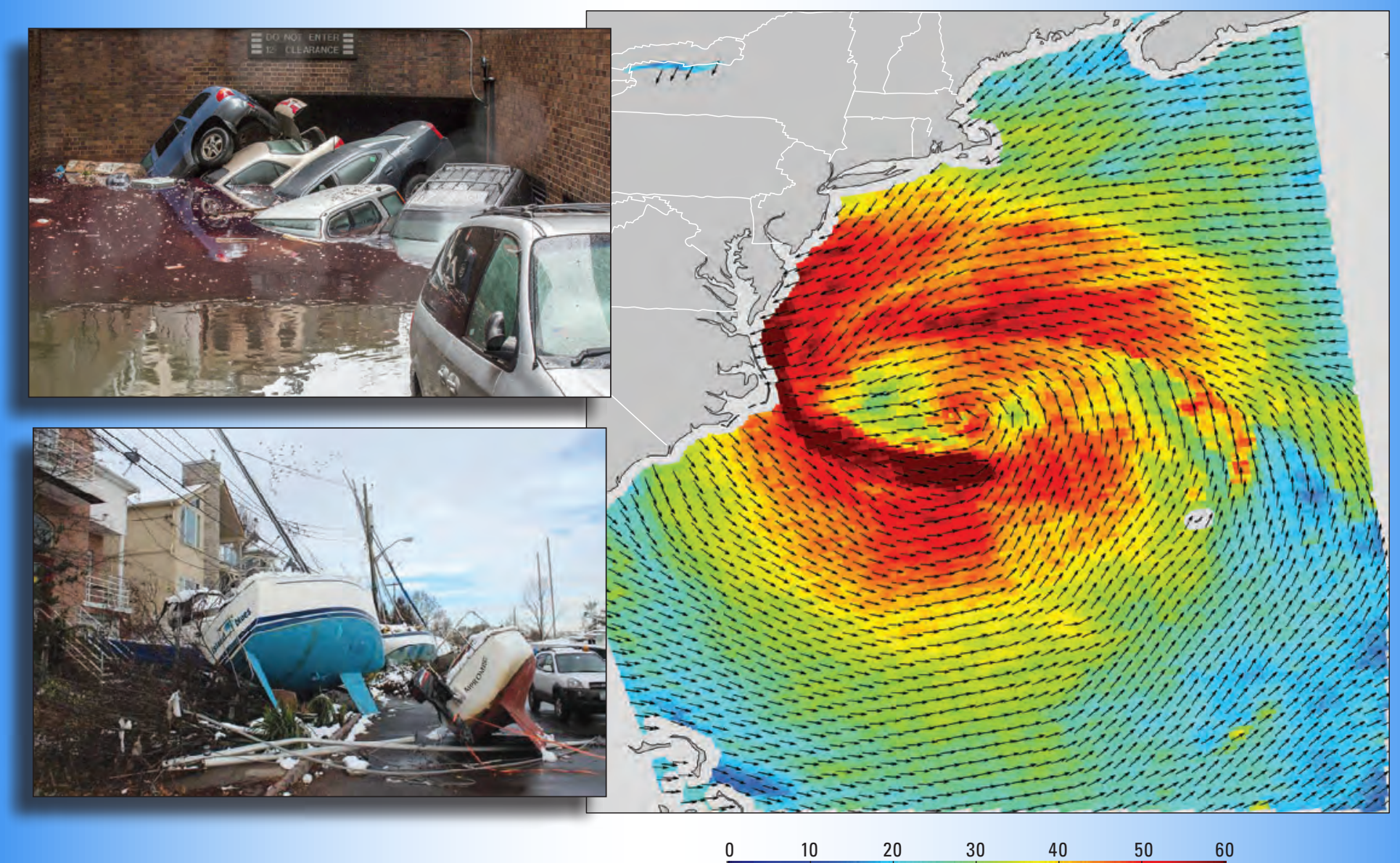

Wind speed, in miles per hour

Scientific Investigations Report 2015-5036

U.S. Department of the Interior U.S. Geological Survey 


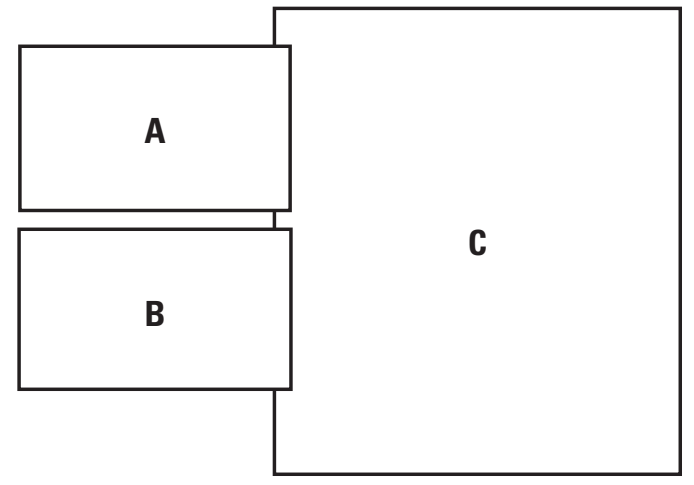

Front cover. $\quad A$, Vehicles partly submerged at an entrance to a flooded parking garage in the Financial District of Manhattan; photograph courtesy of Frankie Torres / Flickr. B, Sailboats stranded in a street in Great Kills, Staten Island; photograph courtesy of the BoatUS Marine Insurance Program. C, Strength and direction of Hurricane Sandy's ocean surface winds on October 28, 2012. Wind speeds above 40 miles per hour (mi/hr) are depicted in yellow, above $50 \mathrm{mi} / \mathrm{hr}$ are in orange, and above $60 \mathrm{mi} / \mathrm{hr}$ are in red; wind directions are indicated by black arrows. Map is modified from National Aeronautics and Space Administration (2013) produced with data from a radar scatterometer on the Indian Space Research Organization's Oceansat-2.

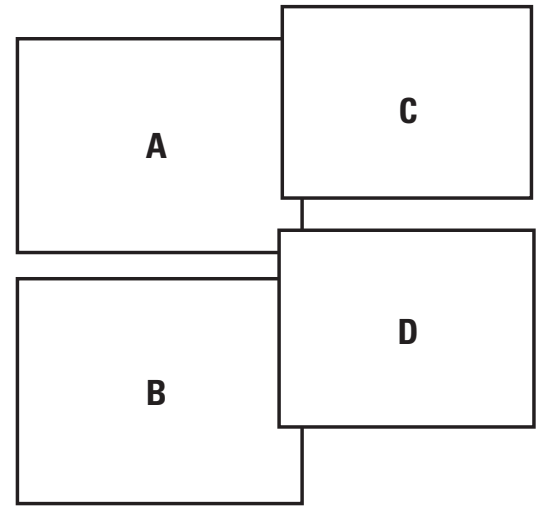

Back cover. $A$, A boardwalk swept off its pilings in Rockaway, Queens; photograph courtesy of John Huntington / Shutterstock. $B$, The 168-foot John B. Caddell water tanker aground in a parking lot in Stapleton, Staten Island; photograph courtesy of Sean Sweeney. C, A vehicle swept off a street in Great Kills, Staten Island; photograph courtesy of Rob Gross / Flickr. D, A boat stranded on the railroad tracks at Metro North's Ossining Station on the Hudson Line; photograph courtesy of the Metropolitan Transportation Authority of the State of New York / Flickr. 


\section{Analysis of Storm-Tide Impacts From Hurricane Sandy in New York}

By Christopher E. Schubert, Ronald Busciolano, Paul P. Hearn, Jr., Ami N. Rahav,

Riley Behrens, Jason Finkelstein, Jack Monti, Jr., and Amy E. Simonson

Prepared in cooperation with the Federal Emergency Management Agency

Scientific Investigations Report 2015-5036 


\title{
U.S. Department of the Interior SALLY JEWELL, Secretary
}

\section{U.S. Geological Survey Suzette M. Kimball, Acting Director}

\author{
U.S. Geological Survey, Reston, Virginia: 2015
}

For more information on the USGS - the Federal source for science about the Earth, its natural and living resources, natural hazards, and the environment-visit http://www.usgs.gov/ or call 1-888-ASK-USGS.

For an overview of USGS information products, including maps, imagery, and publications, visit http://www.usgs.gov/pubprod/.

Any use of trade, firm, or product names is for descriptive purposes only and does not imply endorsement by the U.S. Government.

Although this information product, for the most part, is in the public domain, it also may contain copyrighted materials as noted in the text. Permission to reproduce copyrighted items must be secured from the copyright owner.

Suggested citation:

Schubert, C.E., Busciolano, Ronald, Hearn, P.P., Jr., Rahav, A.N., Behrens, Riley, Finkelstein, Jason, Monti, Jack, Jr., and Simonson, A.E., 2015, Analysis of storm-tide impacts from Hurricane Sandy in New York: U.S. Geological Survey Scientific Investigations Report 2015-5036, 75 p., http://dx.doi.org/10.3133/sir20155036.

ISSN 2328-031X (print) ISSN 2328-0328 (online) 


\section{Acknowledgements}

The authors thank the Federal Emergency Management Agency (FEMA) Region II for support and cooperation under the Stafford Act (42 U.S.C. 5121 et seq.). The assistance of many individuals is greatly appreciated. In particular, the temporary monitoring network deployment and highwater-mark flagging and surveying campaign were undertaken by U.S. Geological Survey (USGS) staff from more than 14 USGS science center offices and 2 USGS storm-surge coordination centers. The authors would also like to highlight the leadership of Alan Springett, risk assessment team lead of FEMA Region II, and Robert Mason, acting chief of the USGS Office of Surface Water, in articulating the need for this novel analysis. Valuable coordination and assistance during the investigation were provided by Brian Lacasse, Craig Skalet, Austen K. Cutrell, and H.E. "Gene" Longenecker III of FEMA and J. Andrew Martin of Dewberry/Risk Assessment, Mapping, and Planning Partners. Thoughtful comments on this manuscript were provided by David Bjerklie and Tristen Tagliaferri of the USGS. 


\section{Contents}

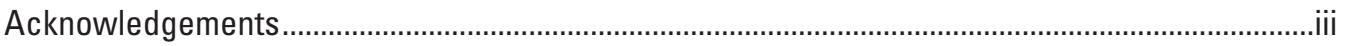

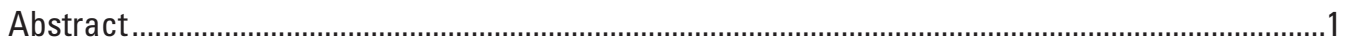

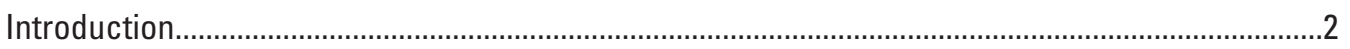

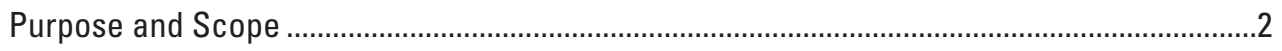

Meteorological History of Hurricane Sandy .............................................................................

Analysis of Storm-Tide Impacts From Hurricane Sandy ................................................................

Peak Storm-Tide Elevation ......................................................................................................

Comparison With Historical Storms ................................................................................

December 1992 Nor'easter .............................................................................

Tropical Storm Irene ........................................................................................ 16

Historical Peak Water-Level Elevations.....................................................................16

Comparison With Annual Exceedance Probabilities .........................................................16

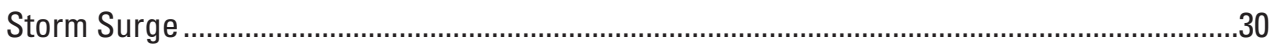

Storm-Surge Magnitude Associated With Peak Storm Tide .............................................30

Magnitude and Timing of Peak Storm Surge ........................................................................

Extent of Storm-Tide Inundation............................................................................................

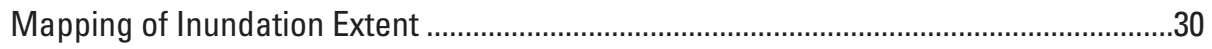

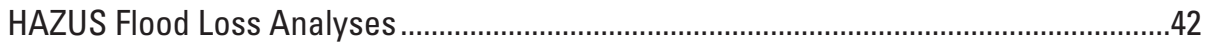

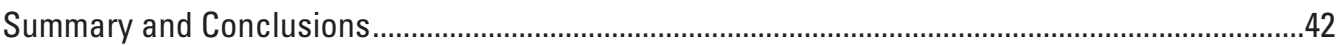

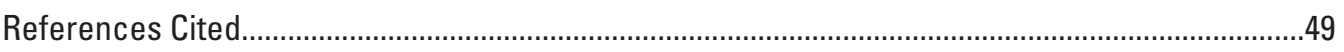

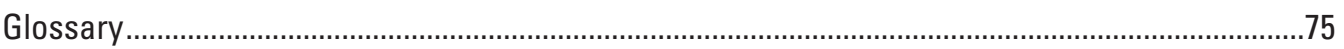

\section{Figures}

1. Map showing location of study area in New York and tracks of Hurricane Sandy, Tropical Storm Irene, and the storm of December 11-13, 1992, in the North Atlantic region.

2. Map showing locations of permanent and temporary monitoring sites and high-water-mark sites that documented the storm tide of Hurricane Sandy in New York

3. Map showing the strength and direction of Hurricane Sandy's ocean surface winds on October 28, 2012

4. Map showing peak storm-tide elevations produced by Hurricane Sandy in New York counties.

5. Schematic diagram showing Federal Emergency Management Agency coastal flood hazard zones and effects of wave heights on base flood elevations.....

6. Maps showing $A$, differences in feet between peak storm-tide elevations, and $B$, differences in percent between peak storm-tide elevations, produced by Hurricane Sandy and the storm of December 11-13, 1992, in New York.

7. Maps showing $A$, differences in feet between peak storm-tide elevations, and $B$, differences in percent between peak storm-tide elevations, produced by Hurricane Sandy and Tropical Storm Irene in New York

8. Map showing selected annual exceedance probabilities for peak storm-tide elevations produced by Hurricane Sandy in New York counties

9. Maps showing $A$, storm-surge magnitude associated with the peak storm tide, and $B$, magnitude of the peak storm surge, produced by Hurricane Sandy in New York counties. 
10. Maps showing extent of storm-tide inundation from Hurricane Sandy in New York counties that was derived from U.S. Geological Survey (USGS) storm-tide data available for $A$, National Hurricane Center Sea, Lake, and Overland Surges from Hurricanes model hindcast product dated October 31, 2012, B, Federal Emergency Management Agency (FEMA) interim high-resolution product based on USGS data available from storm landfall through November 11, 2012, and C, FEMA final high-resolution product based on USGS data available from storm landfall through February 14, 2013

11. Maps showing Federal Emergency Management Agency (FEMA) Hazus Program estimated total building stock losses due to storm-tide inundation from Hurricane Sandy in selected New York counties for inundation depicted in $A$, National Hurricane Center Sea, Lake, and Overland Surges from Hurricanes model hindcast product dated October 31, 2012, B, FEMA interim high-resolution product based on U.S. Geological Survey (USGS) data available from storm landfall through November 11, 2012, and C, FEMA final high-resolution product based on USGS data available from storm landfall through February 14, 2013.

12. Graph showing Federal Emergency Management Agency Hazus Program estimated total building stock losses due to storm-tide inundation from Hurricane Sandy in selected New York counties.

13. Graphs showing differences between Federal Emergency Management Agency Hazus Program estimated total building stock losses due to storm-tide inundation from Hurricane Sandy in selected New York counties.

\section{Tables}

1. Peak storm-tide elevations produced by storm of December 11-13, 1992, at 27 high-water-mark sites, and peak storm-tide elevations produced by Hurricane Sandy at nearby sites in New York

2. Peak storm-tide elevations produced by Hurricane Sandy, Tropical Storm Irene, and historical peak water-level elevations, dates of occurrence, and periods of record at 19 permanent monitoring sites in New York...

3. Peak storm-tide elevations produced by Hurricane Sandy and Tropical Storm Irene at 23 temporary monitoring sites in New York

4. Peak storm-tide elevations produced by Tropical Storm Irene at 10 high-

water-mark sites, and peak storm-tide elevations produced by Hurricane Sandy at nearby sites in New York

5. Peak storm-tide elevations produced by Hurricane Sandy at 24 permanent monitoring sites, and the corresponding Federal Emergency Management Agency flood elevations for the 10-, 2-, 1-, and 0.2-percent annual exceedance probabilities $(10-, 50-, 100-$, and 500-year recurrence intervals) in New York.

6. Peak storm-tide elevations produced by Hurricane Sandy at 43 temporary monitoring sites, and the corresponding Federal Emergency Management Agency flood elevations for the 10-, 2-, 1-, and 0.2-percent annual exceedance probabilities $(10-, 50-, 100-$, and 500-year recurrence intervals) in New York.

7. Peak storm-tide elevations produced by Hurricane Sandy at 346 high-water-mark sites, and the corresponding Federal Emergency Management Agency flood elevations for the 10-, 2-, 1-, and 0.2-percent annual exceedance probabilities (10-, 50-, 100-, and 500-year recurrence intervals) in New York.

8. Storm-surge magnitude associated with the peak storm tide, and magnitude and timing of the peak storm surge, produced by Hurricane Sandy at 18 permanent monitoring sites in New York 


\section{Conversion Factors}

[Inch/Pound to International System of Units]

\begin{tabular}{|c|c|c|}
\hline Multiply & By & To obtain \\
\hline \multicolumn{3}{|c|}{ Length } \\
\hline inch (in.) & 2.54 & centimeter $(\mathrm{cm})$ \\
\hline inch (in.) & 25.4 & millimeter $(\mathrm{mm})$ \\
\hline foot $(\mathrm{ft})$ & 0.3048 & meter $(\mathrm{m})$ \\
\hline mile (mi) & 1.609 & kilometer (km) \\
\hline \multicolumn{3}{|c|}{ Flow rate } \\
\hline mile per hour (mi/h) & 1.609 & kilometer per hour $(\mathrm{km} / \mathrm{h})$ \\
\hline
\end{tabular}

\section{Datum}

Vertical coordinate information is referenced to the North American Vertical Datum of 1988 (NAVD 88) and the National Geodetic Vertical Datum of 1929 (NGVD 29).

Horizontal coordinate information is referenced to the North American Datum of 1983 (NAD 83).

Elevation, as used in this report, refers to distance above the vertical datum.

\section{Abbreviations}

$\begin{array}{ll}\text { BFE } & \text { base flood elevation } \\ \text { FEMA } & \text { Federal Emergency Management Agency } \\ \text { HWM } & \text { high-water mark } \\ \text { NAVD 88 } & \text { North American Vertical Datum of 1988 } \\ \text { NGVD 29 } & \text { National Geodetic Vertical Datum of 1929 } \\ \text { NHC } & \text { National Hurricane Center } \\ \text { NOAA } & \text { National Oceanic and Atmospheric Administration } \\ \text { USGS } & \text { U.S. Geological Survey }\end{array}$




\title{
Analysis of Storm-Tide Impacts From Hurricane Sandy in New York
}

\author{
By Christopher E. Schubert, ${ }^{1}$ Ronald Busciolano, ${ }^{1}$ Paul P. Hearn, Jr., ${ }^{1}$ Ami N. Rahav, ${ }^{2}$ Riley Behrens, ${ }^{1}$ \\ Jason Finkelstein, ${ }^{1}$ Jack Monti, Jr., ${ }^{1}$ and Amy E. Simonson ${ }^{1}$
}

\section{Abstract}

The hybrid cyclone-nor'easter ${ }^{3}$ known as Hurricane Sandy affected the mid-Atlantic and northeastern United States during October 28-30, 2012, causing extensive coastal flooding. Prior to storm landfall, the U.S. Geological Survey (USGS) deployed a temporary monitoring network from Virginia to Maine to record the storm tide and coastal flooding generated by Hurricane Sandy. This sensor network augmented USGS and National Oceanic and Atmospheric Administration (NOAA) networks of permanent monitoring sites that also documented storm surge. Continuous data from these networks were supplemented by an extensive post-storm high-water-mark (HWM) flagging and surveying campaign. The sensor deployment and HWM campaign were conducted under a directed mission assignment by the Federal Emergency Management Agency (FEMA). The need for hydrologic interpretation of monitoring data to assist in flood-damage analysis and future flood mitigation prompted the current analysis of Hurricane Sandy by the USGS under this FEMA mission assignment.

The analysis of storm-tide impacts focused on three distinct but related aspects of coastal flooding from Hurricane Sandy, including flooding inland along the tidal reach of the Hudson River. These aspects are (1) comparisons of peak storm-tide elevations to those of historical storms and to annual exceedance probabilities, (2) assessments of storm-surge characteristics, and (3) comparisons of maps of inundation extent that were derived from differing amounts of available storm-tide data. Most peak storm-tide elevations from Hurricane Sandy were greater than about 9.5 feet (ft) above North American Vertical Datum of 1988.

Peak storm-tide elevations from Hurricane Sandy were compared with data for the intense nor'easter of December 11-13, 1992, and Hurricane Irene (August 27-28, 2011), which weakened to a tropical storm before arriving in New York. Peak storm-tide elevations from Hurricane Sandy were higher than those from the December 1992 nor'easter at 24 of 27 sites; most differences were greater than about $0.7 \mathrm{ft}$

\footnotetext{
${ }^{1}$ U.S. Geological Survey

${ }^{2}$ Harris IT Contracting

${ }^{3}$ Bold text is defined in the glossary.
}

or 9 percent (above the historical storm tide). Peak storm-tide elevations from Hurricane Sandy were higher than those from Tropical Storm Irene at all sites; most differences were greater than about $2.5 \mathrm{ft}$ or 48 percent. Data from permanent and temporary monitoring sites and HWM sites were compared with corresponding FEMA flood elevations for the 10-, 2-, 1-, and 0.2-percent annual exceedance probabilities in New York. Peak storm-tide elevations from Hurricane Sandy had annual exceedance probabilities less than or equal to 1 percent and (or) greater than 0.2 percent at a plurality of sites -184 of 413 . Peak storm-tide elevations greater than or equal to the 0.2-percent flood elevation accounted for 81 of 413 sites. Peak storm-tide elevations less than the 10-percent flood elevation accounted for only 10 of 413 sites.

Data from selected permanent monitoring sites in the USGS and NOAA networks were used to assess storm-surge magnitude associated with the peak storm tide, and magnitude and timing of the peak storm surge. Most magnitudes of the peak storm surge were greater than about $8.3 \mathrm{ft}$, and most magnitudes of the storm surge component of the peak storm tide were greater than about $7.8 \mathrm{ft}$. Timing of peak storm surge arrival with respect to local phase of tide controlled where the most extreme peak storm-tide levels and coastal flooding occurred. This finding has bearing not only for locations impacted by the highest storm tides from Hurricane Sandy, but also for those that had the greatest storm surges yet were spared the worst flooding because of fortuitous timing during this storm.

Results of FEMA Hazus Program (HAZUS) flood loss analyses performed for New York counties were compared for extents of storm-tide inundation from Hurricane Sandy mapped (1) pre-storm, (2) on November 11, 2012, and (3) on February 14, 2013. The resulting depictions of estimated total building stock losses document how differing amounts of available USGS data affect the resolution and accuracy of storm-tide inundation extents. Using the most accurate results from the final (February 14, 2013) inundation extent, estimated losses range from $\$ 380$ million to $\$ 5.9$ billion for individual New York counties; total estimated aggregate losses are about $\$ 23$ billion for all New York counties. Quality of the inundation extents used in HAZUS analyses has a substantial effect on final results. These findings can be used to inform future post-storm reconstruction planning and estimation of insurance claims. 


\section{Introduction}

The hybrid cyclone nor'easter known as Hurricane Sandy affected the mid-Atlantic and northeastern coastline of the United States during October 28-30, 2012 (fig. 1), producing northeast-to-southeast winds of tropical-storm strength (39 to 73 miles per hour [mi/hr] that gusted to greater than hurricane strength (greater than $73 \mathrm{mi} / \mathrm{hr}$ ) and causing extensive coastal flooding and beach erosion. Severe tidal flooding occurred along coastal areas of southeastern New York, northem New Jersey, and southern Connecticut during the afternoo New Jersey, and sont so October 30 . Although peak storm-tide levels occurred ne the times of normal tidal high water during October 29-30, widespread tidal flooding that began during the morning of October 29 did not subside in some coastal areas until October 31 .

Prior to storm landfall, the U.S. Geological Survey (USGS) deployed a temporary monitoring network of waterlevel and barometric pressure sensors to continuously record the timing, areal extent, and magnitude of the storm tide and coastal flooding generated by Hurricane Sandy (McCallum and others, 2013). Sensors were deployed at 224 locations along the Atlantic coast from Virginia to Maine, including 59 in New York alone (fig. 2). The temporary monitoring network augmented USGS and National Oceanic and Atmospheric Administration (NOAA) networks of permanent mo toring sites (fig. 2) that also documented storm surge- - the difference (when positive) between the observed water level and the normal (predicted astronomical) tide level. Continuous data from these networks were greatly supplemented by an extensive post-storm high-water-mark (HWM) flagging a surveying campaign from November to December 2012. More than $950 \mathrm{HWMs}$ were measured along the mid-Atlantic and northeastern coastline; roughly one-third of these were measured in southeastern New York and north along the Hudson River to the head-of-tide at the Federal Dam in Troy (fig 2) The temporary monitoring network deployment and HWM flagging and surveying campaign were undertaken as part of a coordinated Federal emergency response as outlined by the Stafford Act (Robert T. Stafford Disaster Relief and Emergency Management Act, Public Law 93-288, as amended, 42 U.S.C. 5121 et seq.) under a directed mission assignment by the Federal Emergency Management Agency (FEMA). The methods and data associated with these activities are described in a rapid-delivery report that provides a quantitative historical record of Hurricane Sandy (McCallum and others, 2013). The need for hydrologic interpretation of monitoring data to assist in the analysis of flood damages an future flood-mitigation efforts in New York prompted the current analysis of Hurricane Sandy under this mission assignment with FEMA. This interpretation was conducted by the USGS in cooperation with FEMA.

\section{Purpose and Scope}

This report presents the results of an analysis of stormtide impacts from Hurncane Sandy in New York that was don as part of the FEMA mission assignment. Specifically, the report presents (I) comparisons or peak storm-tide elevations to selected historical storms and annual exceedance probabilties; (2) the storm-surge magnitude associated with the peak storm tide, and magnitude and timing of the peak storm surge; and (3) comparisons of selected maps of inundation extent that HWM data

\section{Meteorological History of Hurricane Sandy}

Hurricane Sandy was the 18th named storm and 10th hurricane of the 2012 Allantic hurricane season. Sandy developed from a low pressure system in the Caribbean Sea. Hurricane Sandy was first classified by the National Hurricane Center (NHC) as a tropical depression and then as a tropical storm south of the island of Jamaica on October 22, 2012. After drifting slowly southwest on October 23, on October 24 Sandy turned to the north and intensified into a Category 1 hurricane on the Saffir-Simpson huricane scale (National Hurticane Con

Hurricane Sandy continued to the north, intensified into a strong Category 2 hurricane before making landfall in Cuba and then emerged on the north side of Cuba during the morning of October 25. The storm proceeded to drift northwest as a Catober 25 and 26 . Hunicas it moved through the Bahamas on October 25 and 26 . Huricane Sandy then began a north-notheast track on October 26 as a Category 1 hurricane (fig. 1). Huric Cin 29. Huc City, New Jesy, as an extra 7 . Cins pressure 945 milliban. The stom moved inland ov New Jessey and weked 3 . sylvania on October 31

horthest motion of the storm that The 18 was caused by two factor: (1) an an alously strong blocking high-pressure system situated over the Canadin Maritimes and (2) an approaching and deepening midlatitude trough to the west over the eastern United States. These factors caused the storm to curve toward the coast south of New York City and Long Island. Hurricane Sandy's interaction with these two weather systems also caused the storm's transition from a tropical to a post-tropical system, which created an outward expansion of the storm's wind field. Just prior to United States landfall, this wind field or fetch was estimated to be about 1,000 miles (mi) wide (fig. 3), making Sandy the largest Atlantic Hurricane on record (Blake and others, 2013). The extremely large fetch of tropical-storm force winds circulating around Hurricane Sandy, combined with its

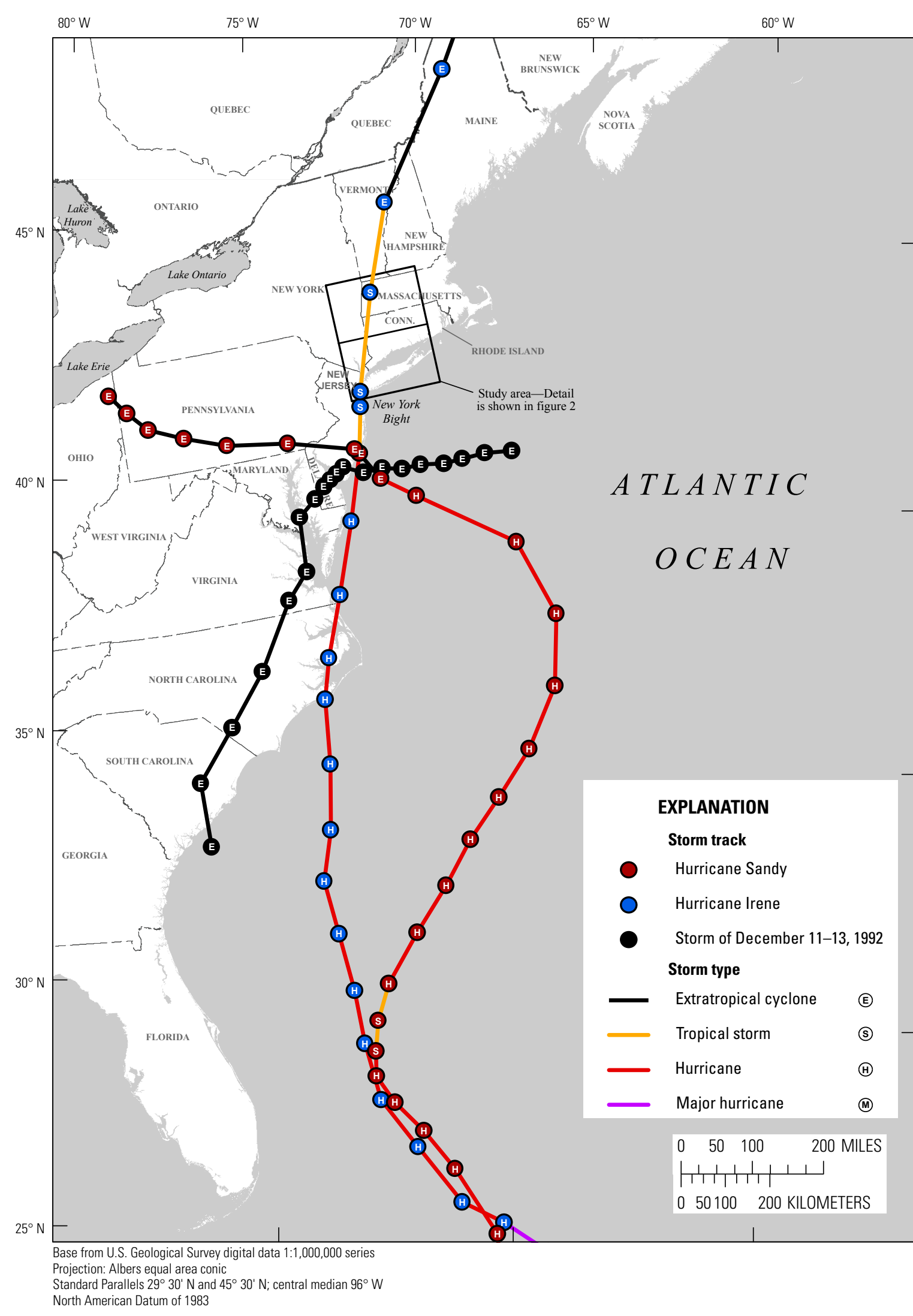

Figure 1. Location of study area in New York and tracks of Hurricane Sandy, Tropical Storm Irene, and the storm of December 11-13, 1992, in the North Atlantic region. Storm position and intensity values for Hurricane Sandy and Tropical Storm Irene are from National Hurricane Center (2013a). Position values for storm of December 11-13, 1992, are from Andrew Cox (Oceanweather, Inc., written commun., 2013). 

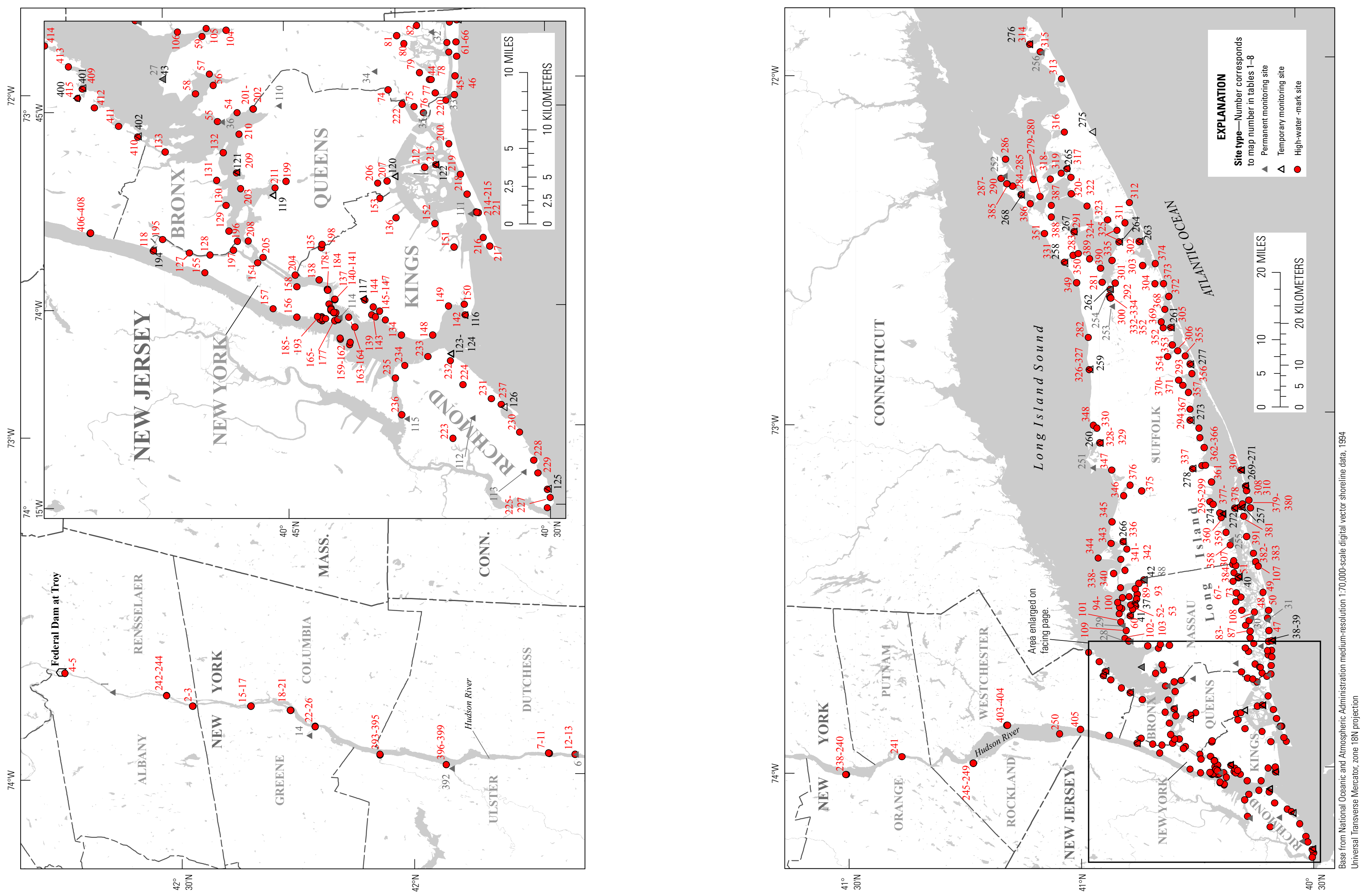
anomalous track, piled large amounts of ocean water over multiple tidal cycles north and west of the center of counterclockwise circulation. This onshore flow was funneled into the New York Bight-the large embayment formed by the Atlantic
coastline of Long Island and northern New Jersey - and inlan coastline of Long Island and northern New Jersey - and inlar
through the many interconnected estuaries, propagating more than 100 mi north along the Hudson River to the head-of-tide at the Federal Dam in Troy. These are the primary reason these areas, producing a storm surge mush greater th expected for Cotegory 1 hurice taking a more non th north-to-northeast track up the Atlantic seabord.

Winds in the southeastern New York region began to increase well in advance of Hurricane Sandy. By the aftenoo of October 27, as Hurricane Sandy was moving northeast along the southeastern United States coast, winds in the region began to increase from an east to northeast direction. This wa primarily due to the pressure gradient between the hurricane

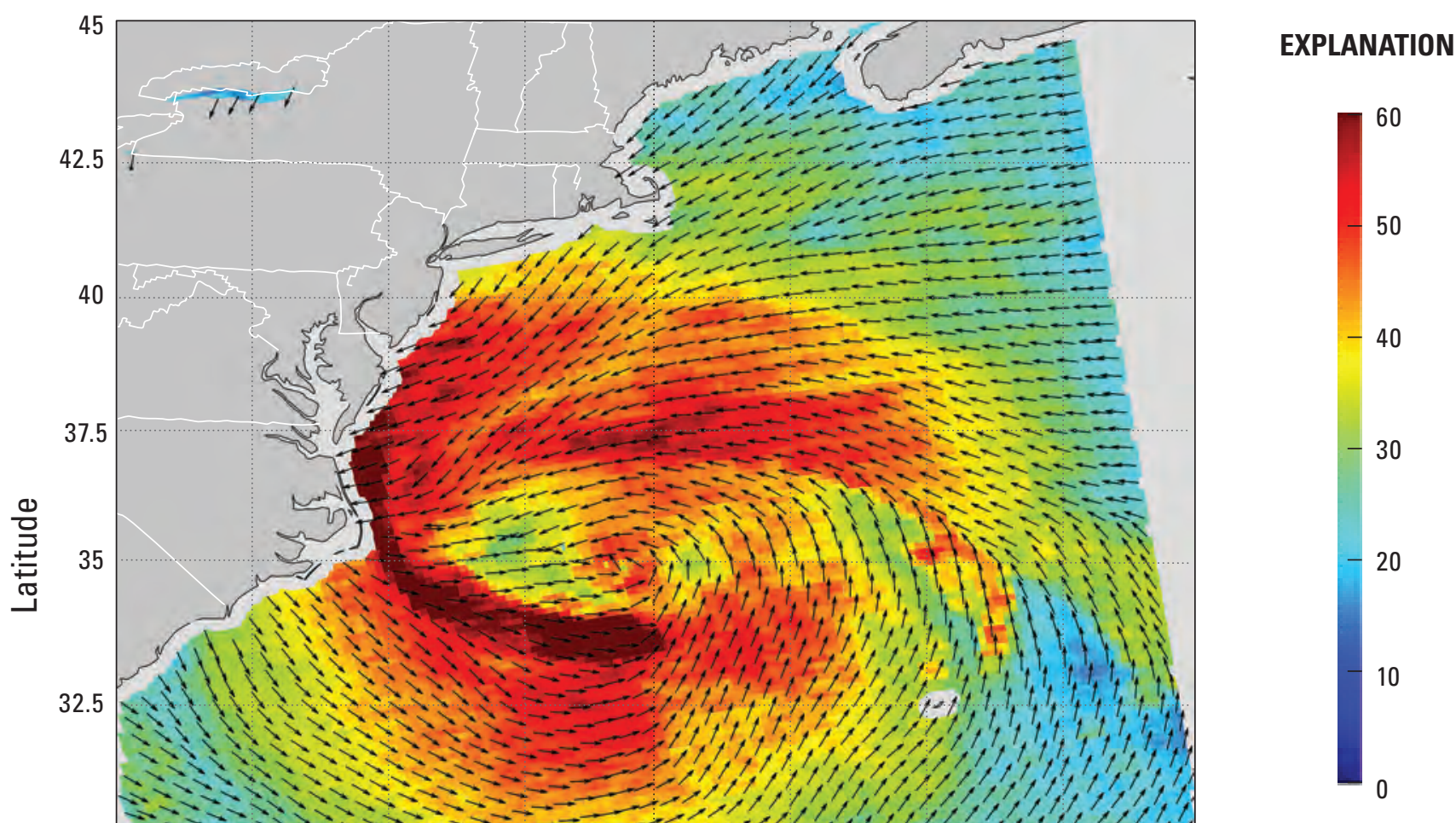

30

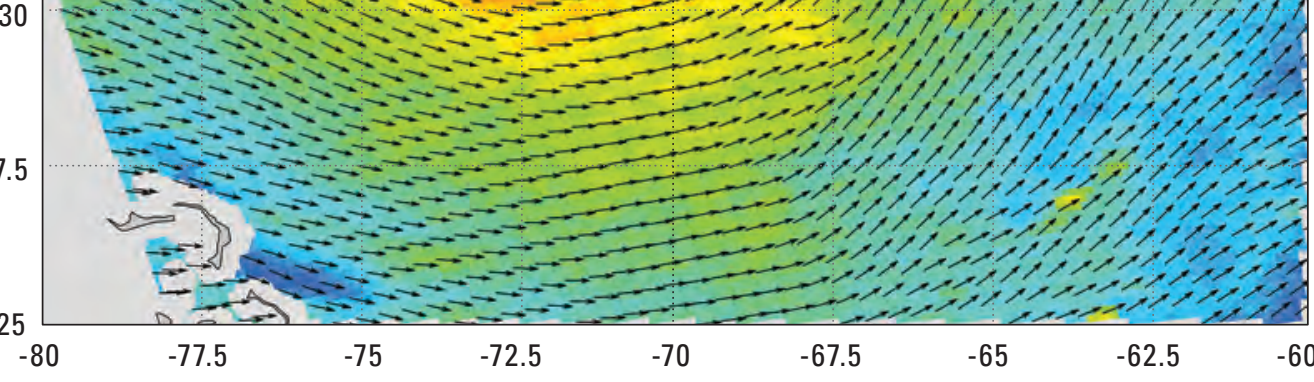

Wind speed, in miles per hour

Longitude well to the south and the blocking high to the northeast of Carina, Ar the afternoon of October 28 , winds began to shiff arthes by the end direction; winds shifted to the northmoving northeastward well east of Cape Hatteras. During the day on October 29, the storm began its sharp turn towards the shifting back to the northeast. Maximum winds occur and late in the afternon to around midnight on October 29 . As the torm approached and then made landfall south of the region, the strong winds quickly switched to an easterly direction by late afternoon and then to a southeasterly direction jus after landfall. As the storm continued moving inland throug southern New Jersey and then into Pennsylvania, strong winds from the southeast to south continued for a few hours and then gradually decreased during the day on October 30 . the region. As the storm approached Cape Hatteras, Nort southern New Jersey coast and transitioned to a post-tropica
Analysis of Storm-Tide Impacts From Hurricane Sandy

The analysis of storm-tide impacts focused on three distinct but related aspects of coastal flooding produced by Hurricane Sandy - (1) comparisons of peak storm-tide elevations to historical storms and annual exceedance probabilities (2) identification of he ston-surge magnitude associated w the peak storm tide, and magnitude and timing of the peak sto able sensor and HWM data.

\section{Peak Storm-Tide Elevation}

Peak storm-tide elevations at the permanent and temporary monitoring sites and HWM sites shown in figure 4 provide comprehensive depiction of the coastal flooding from Hurrican Sandy in New York. The data for these sites are also available from a USGS interactive storm-tide mapper at http://water.usg. gov/floods/events/2012/sandy/sandymapper.html. The stormtide elevations have been affected by wave action to varying degrees, depending on the measurement techniques and site conditions under which the data were collected. A diagram of FEMA coastal flood hazard zones and the manner in which wave heights affect base flood elevations (BFEs), particularly at locations in VE zones (Federal Emergency Management Agency, 2013a) is shown in figure 5. Specifically, these locations are likely to have flooding with wave heights of 3 feet (fi) or greater, whereas those in AE zones wil have flooding with

As a result, records from permanent and temporary monitoring sites in $V E$ zones likely were affected by wave heights of 1 or with stillwater elevation; mito other coastal flood hazard zones likely were affected by wave heights less than $3 \mathrm{ft}$ and, thus, provide a peak elevation gene ally comparable with the corresponding stillwater elevabs. ally comparable with the corresponding stillwater elevations. wave heights of $3 \mathrm{ft}$ or greater and therefore, are compable only with the BFEs. HWMs at sites in other constal flood hazard zones likely were affected by wave heights less the $3 \mathrm{ft}$ and, thus, are generally comparable with the correspondig stillwater elevations.

Most peak storm-tide elevations from Hurricane Sandy (fig. 4) were greater than about 9.5 ft above North American
Vertical Datum of 1988 (NAVD 88); this level was exceeded at most of the sites in Albany, Nassau, Rensselaer, and Westchester Counties and New York City (Bronx, Kings, New York, Queens, and Richmond Counties). In the remaining counties with Hurricane Sandy data-Dutchess, Greene, Orange, Rockland, Suffolk, and Ulster, peak storm-tide elevations were greater than about $7.2 \mathrm{ft}$ above NAVD 88 at most sites. The maximum peak storm-tide elevation was $16.9 \mathrm{ft}$ above NAVD 88 at HWM site HWM-NY-RIC-717 (map number 230) in New York City. The minimum peak storm-tide elevation was $3.5 \mathrm{ft}$ above NAVD 88 at HWM site HWM-NY-SUF-638 (map number 373) in Suffolk County. Data were not obtained along the east shore of the Hudson River hi Columba and Punam contres, HWMs obtained nties represent peak storm-tide elevations in these reaches.

Comparison With Historical Storms

Peak storm-tide elevations produced by Hurricane Sandy were compared with those of historical storms for which dat on substantial coastal flooding are available. These storms include the intense nor easter of December 11-13, 1992, an tropical storm before arriving in New York.

\section{December 1992 Nor'easter}

The intense nor'easter that affected the mid-Atlantic and northeastern coastline of the United States during Decenter 10-14, 1992 (fig. 1), produced east-to-northeast (t) great than hurricane strength and caused heavy rain, extensive coastal flooding, and severe beach erosion (Schubert and Busciolano, 1994). Severe tidal flooding occurred during the moning of December 11 and continued through the early afternooof December 12 along coastal areas of southeastern New York, northern New Jersey, and southern Connecticut. Although peak storm-tide levels occurred near the times of normal tidal high water during December 11-12, widespread tidal flooding did not subside in many coastal areas until December 14 . Peak storm-tide elevations produced by the storm of December 11-13, 1992, at 27 HWM sites and peak stormtide elevations produced by Hurricane Sandy at nearby sites in New York are listed in table 1. Calculations of the differin 1 , and the differences a depicted in perent respectively. Thes diffeces ind elevations from Hurricane Sandy were higher than those from the Decenter 1992 nor' Most differences were greeter than abou $0.7 \mathrm{ft}$ or 9 percent with most of these from sites along the Atlantic Ocean shores of Nassau and Suffolk Counties and New York City The maxiof Nassau and Suffolk Counties and New York City. The maxiQUE-505 (Hunters Point) in New York City, and the maximum relative difference was 110 percent at HWM sites HWM-NYSUF-407 (Bay Shore), HWM-NY-SUF-600 (Oakdale), and HWM-NY-SUF-620 (Bellport) along the Atlantic Ocean shore of Suffolk County. The minimum absolute and relative differences were $-0.5 \mathrm{ft}$ and -4 percent, respectively, at HWM site HWM-NY-NAS-936 (Bayville) along the Long Island Sound shore of Nassau County.

3. Strength and direction of Hurricane Sandy's ocean surface winds on 0ctober 28, 2012. Wind speeds above 40 miles per hour from National Aeronautics and Space Administration (2013) produced with data from a radar scaterometer on the Research Organization's Ocens Space Ad 
8 Analysis of Storm-Tide Impacts From Hurricane Sandy in New York

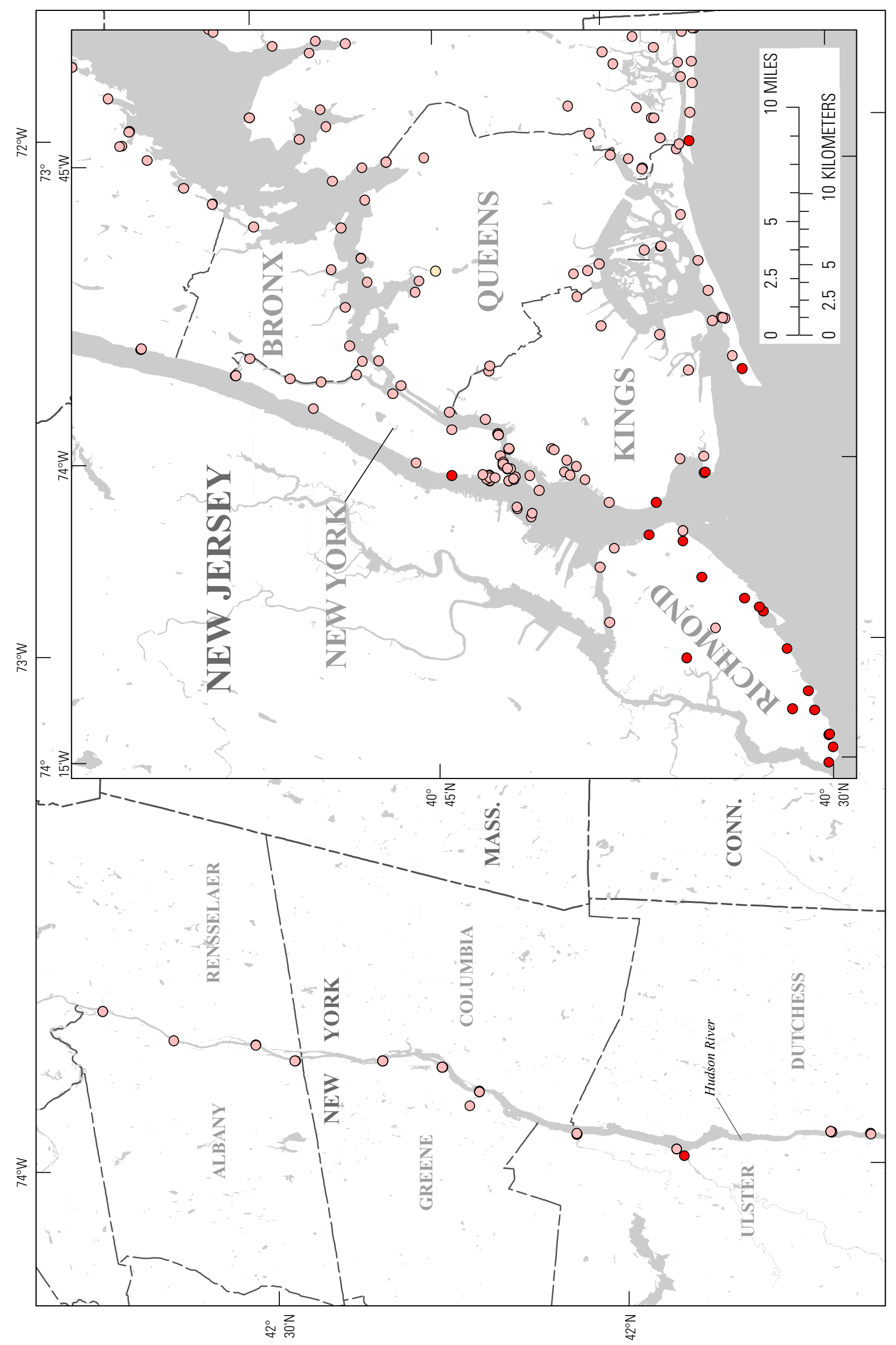

Analysis of Storm-Tide Impacts From Hurricane Sandy $\quad 9$

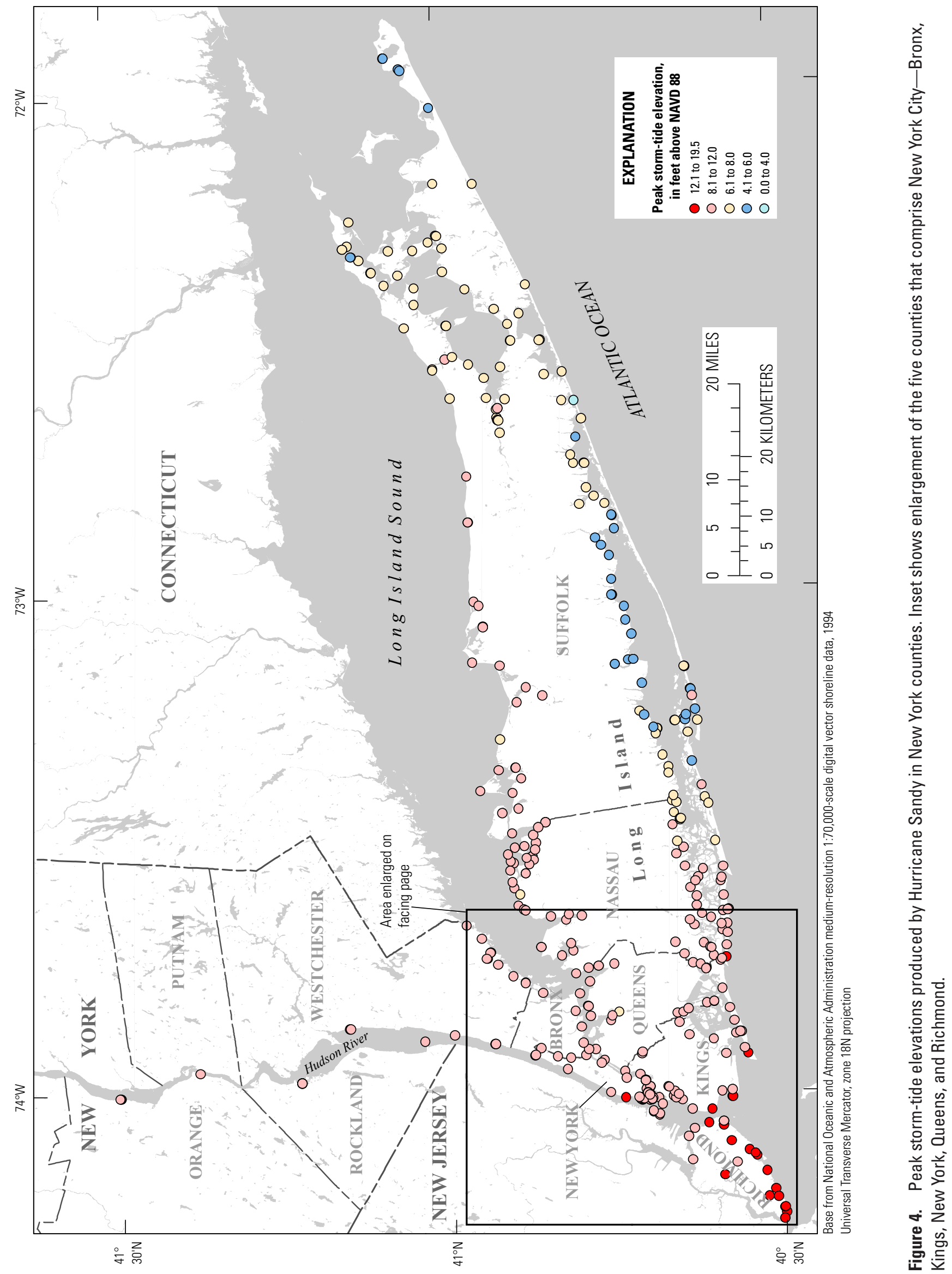




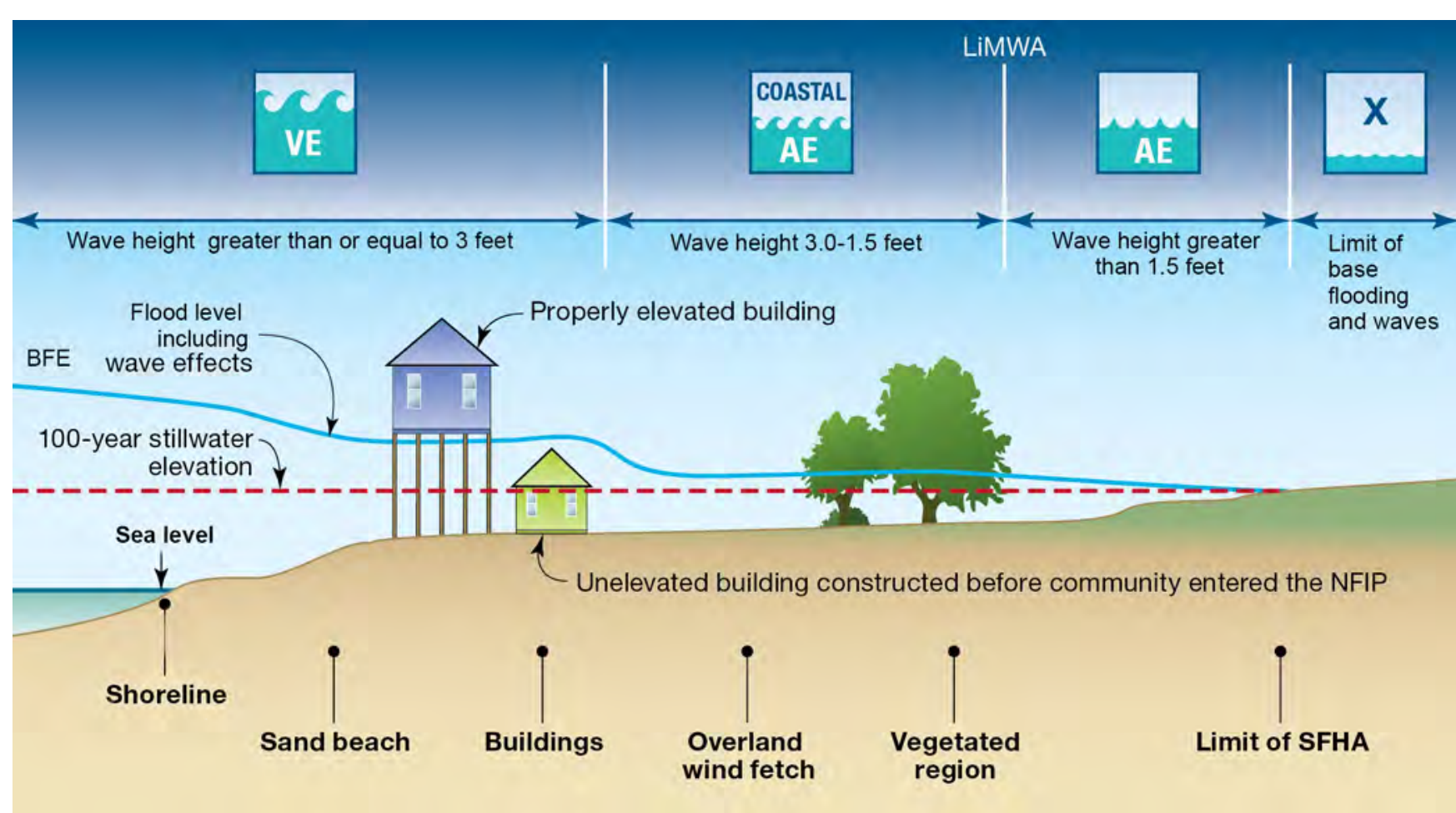

Figure 5. Federal Emergency Management Agency coastal flood hazard zones and effects of wave heights on base flood elevations (BFEs), particularly at locations in the VE zone; from Federal Emergency Management Agency, 2013a. VE zone is the area subject to high velocity wave action (a 3-foot breaking wave) from the 1-percent annual chance coastal flood. AE zone is the area subject to inundation from the 1-percent annual chance flood; these areas are not subject to high velocity wave action but are still considered high risk flooding areas. X zone is the area of moderate coastal flood risk outside the regulatory 1-percent annual Program; SFHA, special flood hazard area.

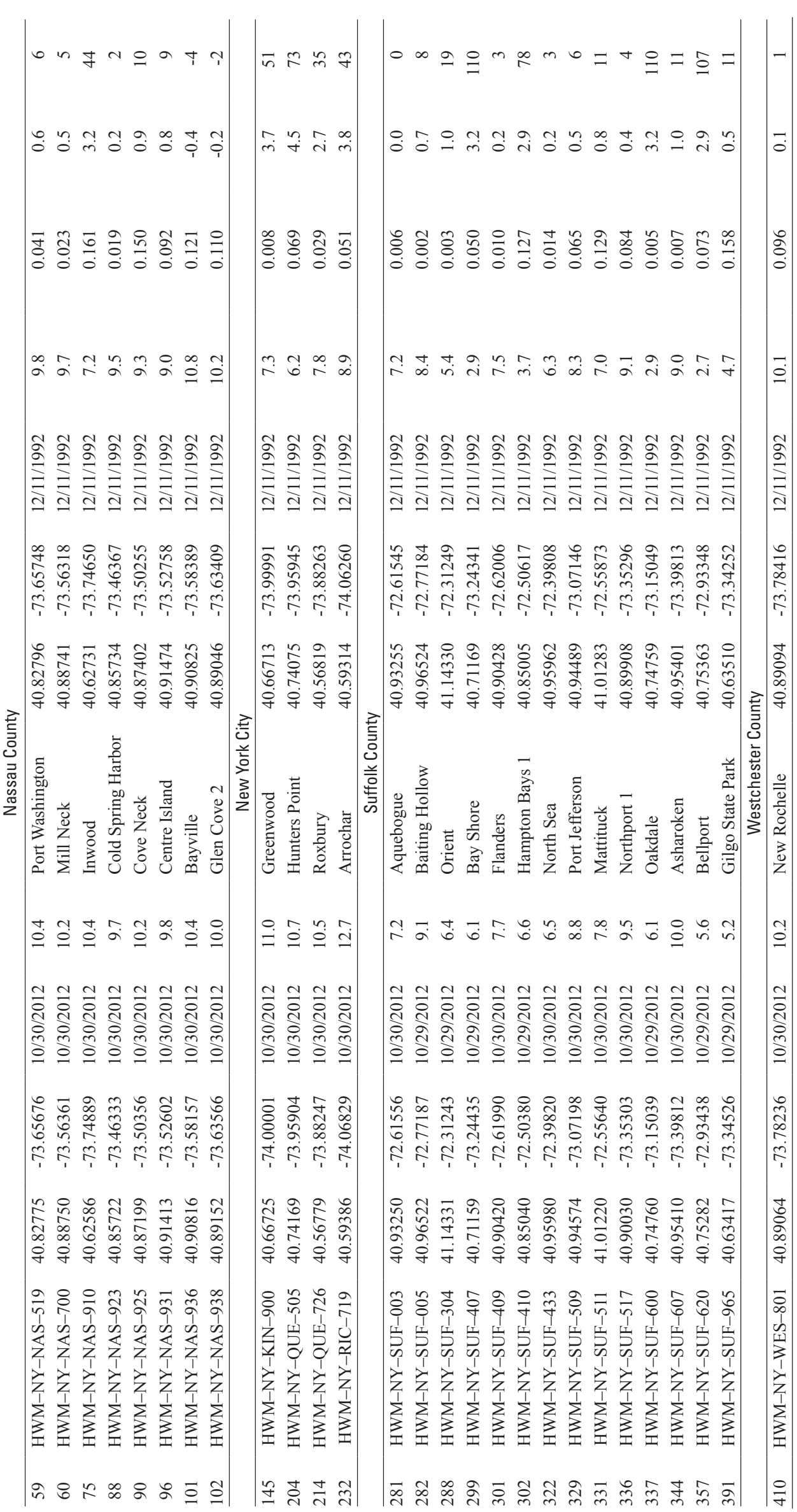



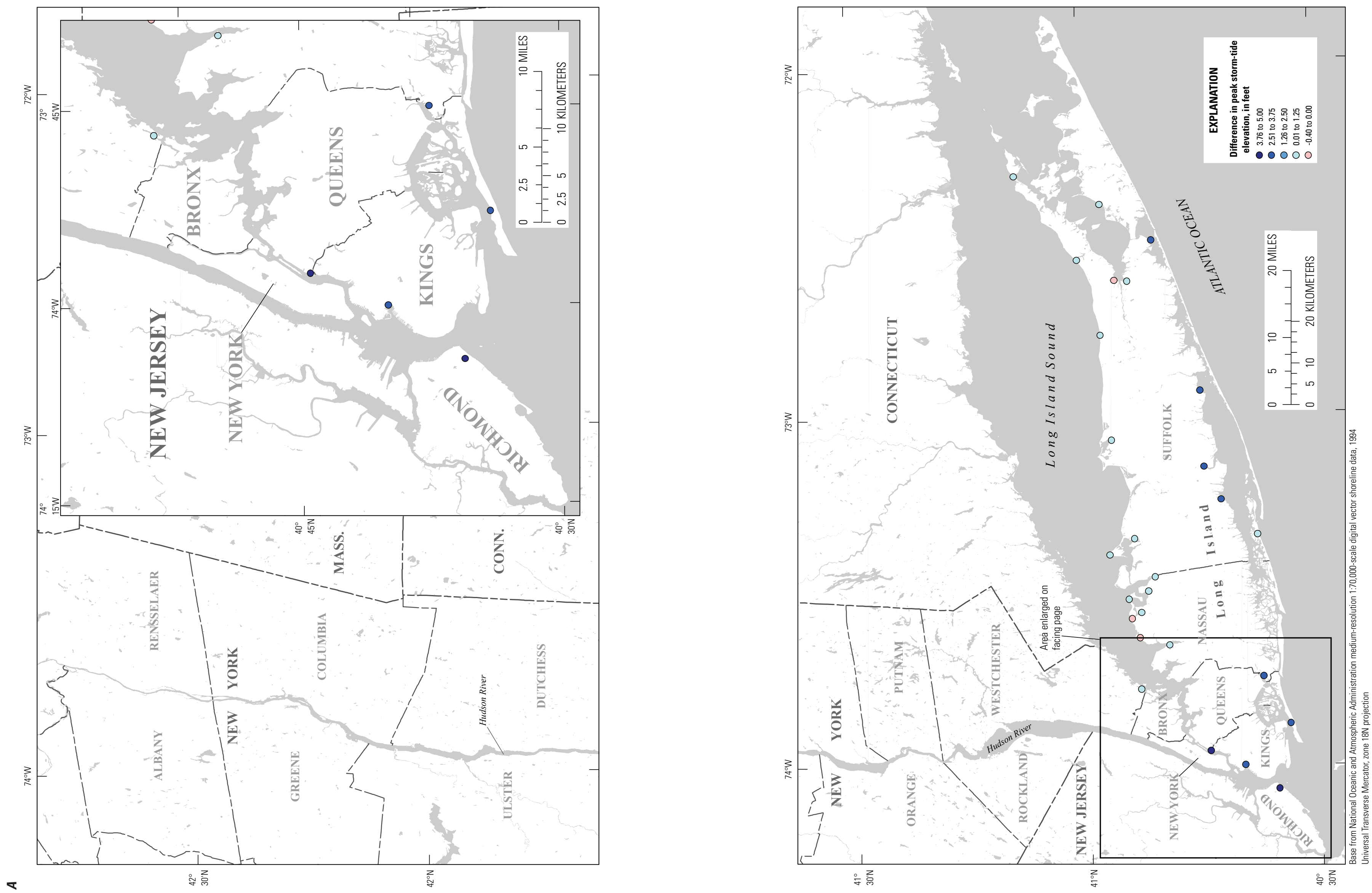

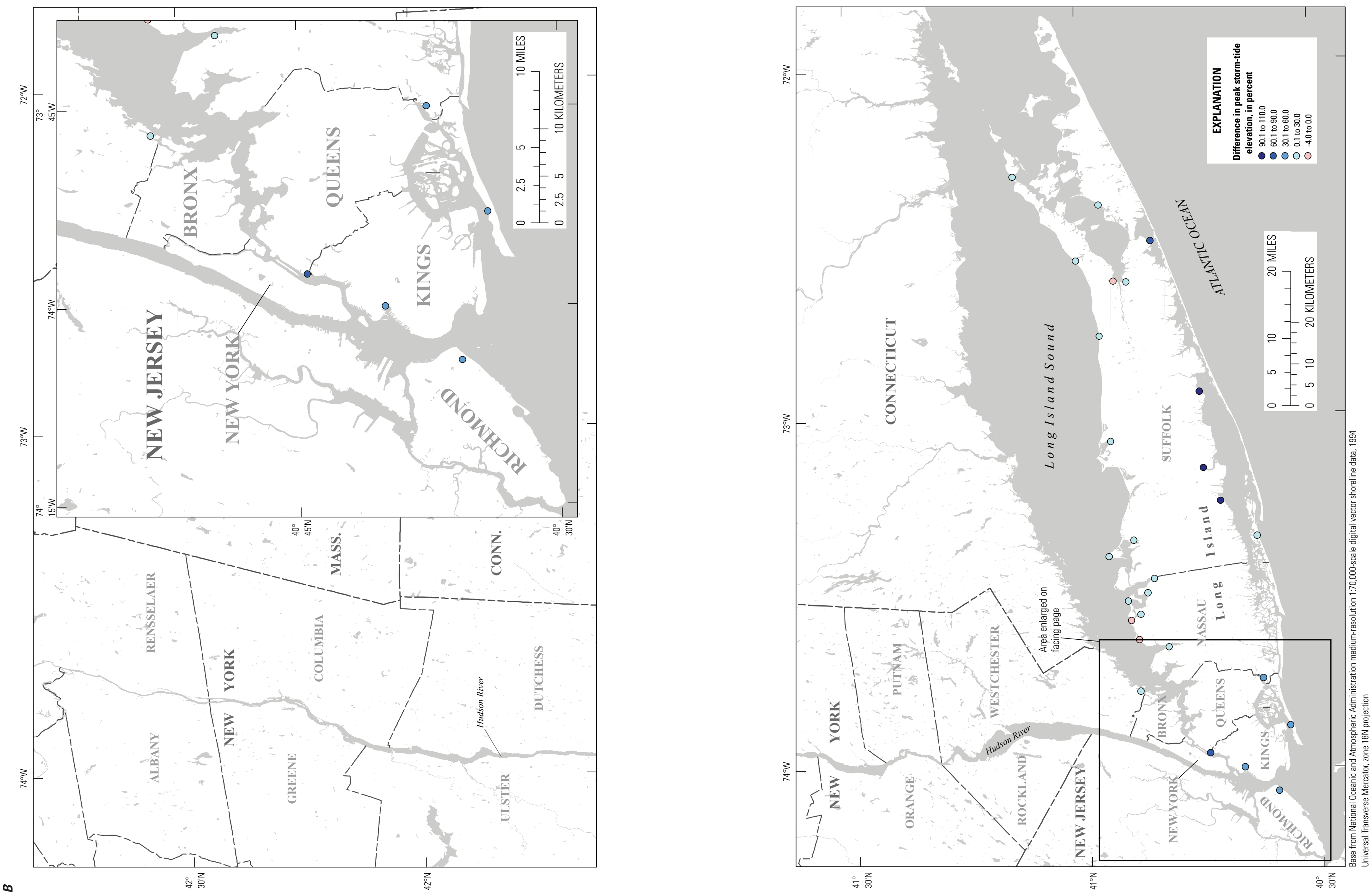


\section{Tropical Storm Irene}

Tropical Storm Irene initially made landfall as a Category 1 hurricane on the North Carolina coast near Beaufort on August 27, 2011 (fig. 1); after traversing the coast and Outer Banks of North Carolina, the storm went back out to sea and made a second landfall as a Category 1 hurricane nea Atlantic City, New Jersey, on August 28 (McCallum and others, 2012). The resulting storm tide reached National Weathe Service moderate to major flood thresholds in coastal areas of Long Island and New York City as Irene crossed western Long Island on August 28 as a tropical storm (Busciolano and Schubert, 2012).

Peak storm-tide elevations produced by Hurricane Sandy and Tropical Storm Irene at 19 permanent monitoring sites, 23 temporary monitoring sites, and $10 \mathrm{HWM}$ sites in New York are given in tables 2,3, and 4, respectively. The data in tables 2 through 4 include the differences between their peak storm-tide elevations for the two storms; differences in elevations are depicted in units of feet and percent in figure $7 A$ and $7 B$, respectively. These differences indicate that peak storm-tide elevations from Hurricane Sandy were higher than those from Tropical Storm Irene at all sites. Most differences were greater than about $2.5 \mathrm{ft}$ or 48 percent, with most of these from sites along the Allantic Ocean shores of I Couty. The maim , in HWM site HWM-NY - RIC 719 (005-CNY-01-006) in New York City (table 4) and the maximum relative difference was 111 percent HWM site HWM-NY-KIN-908 (005-CNY 02-003), also in New York City. The minimum absolute and relative differences were $0.14 \mathrm{ftand} 1.7 \mathrm{percent}$, respectively, relative difrerences wero 0.14 th and 1.7 percent, respectively, along the Long Island Sound shore of Suffolk County.

\section{Historical Peak Water-Level Elevations}

Peak storm-tide elevations produced by Hurricane Sandy, historical peak water-level elevations, estimated dates of occurence, and periods of record at 19 permanent monitoring sits in New York are presented in table 2. Of the 19 permanent monitoring sites, he peak ston-tide elevation from Hurricane 16 sites (84 percent) and was very close to te hictor at 1 site ( 5 percent). One of the two sites where the historical peak was greater than the peak from Huricane Sandy-USGS pea 01302050 - is a streame in New York City thas hist cally may have been affected by high streamflow. The orter site-NOAA site 8510560 - is a tide gage in Suffolk County near the extreme eastern tip of Long Island, where the storm tide impacts from Hurricane Sandy were less than those at sites farther westward. The one site where the peak from Hurricane Sandy was very close to but did not exceed, the historical peak-USGS streamgae 01303000 - is along the Long Is Sound shore of Nassau County. This historical peak is from the unnamed, major hurricane of September 21, 1938; however, it was only $0.06 \mathrm{ft}$ higher than the peak from Hurricane Sandy.
Comparison With Annual Exceedance Probabilities

Peak storm-tide elevations at the permanent and temporary monitoring sites and the HWM sites were compared wit the corresponding FEMA flood elevations for the 10-, 2-, 1-, and 0.2-percent annual exceedance probabilities (10-, 50-, 100-, and 500-year recurrence intervals). The comparison relied on stillwater flood elevations, and on coastal flood hazard zones an base flood elevations, which we generally derived from the Flood Inura par were in of Hurricas Sand Ore exeption to this was in New Yor City, where the comparison relied primarily on costal flood hazard zones and flood elevations derived from preliminary work map data (Federal Emergency Manogement Agency, 2013e), which represent the best available information at the time of this study. A comparison of peak storm-tide elevations to annul exceedy. probabilities for New York City was also performed using the most recently published FEMA FIS and FIRM products for this locality; the data are listed in tables 5 through 7 . However, this comparison with legacy products is not discussed in the text or shown in the figures.

Peak storm-tide elevations produced by Hurricane Sandy and the corresponding FEMA flood elevations for the 10-, 2-, 1-, and 0.2-percent annual exceedance probabilities (10-, 50-, 100-, and 500-year recurrence intervals) at 24 permanent honitoring sites, 43 temporary monitoring sites, and 346 HWM sites in New York are listed in tables 5, 6, and 7, respectively. The comparisons between Hurricane Sandy peak storm-tide elevations and FEMA flood elevations for sites in tables 5 through 7 also include the annual exceedance probabilities (and recurrence intervals) for these sites; annual exceedance probabilitities are shown in figure 8 . These comparisons indicate that peak storm-tide elevations from Hurricane Sandy had annual exceedance probabilities of less than or equal to 1 percent and (or) greater than 0.2 percent (recurrence intervals greater than or equal to 100 years and (or) less tha

Most of the peak storm-tide elevations greater than or equal the FEMA 1-percent (100-year) flood elevation and (or) less than the 0.2 -percent (500-year) flood elevation were from sites Dutchess, Nassau, Orange, Rockland, Suffolk, and Ulster Counties; New York City; and along the Hudson River shore of Westchester County (fig. 8). Peak storm-tide elevations associated with the minimum annual exceedance probabilities (maximum recurrence intervals) - elevations higher than or equal to the FEMA 02-percent (500-year) flood elevation - accounted for 81 of 413 sites ( 20 percent); most of these were along the Atlantic Ocean shores of Nassau and western Suffolk Counties, in Orange and Rockland Counties, and along the Hudson River shore of Westchester County. Peak storm-tide elevations associated with the maximum annual exceedance probability (minimum recurrence interval) - elevations lower than the FEMA 10-percent (10-year) flood elevation - accounted for only 10 of 413 sites (2 percent); most of these were in Albany and Rensselaer Counties.

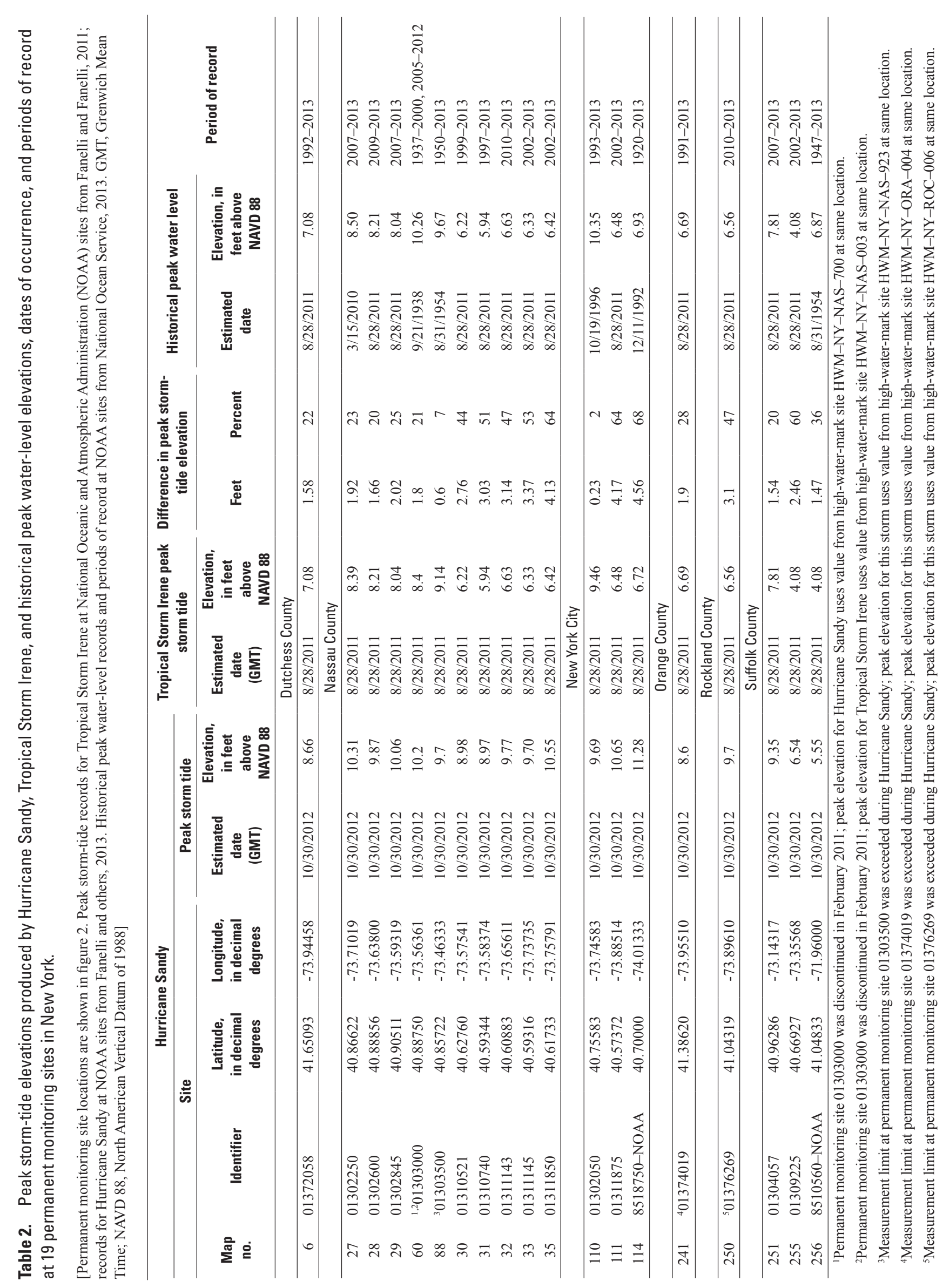



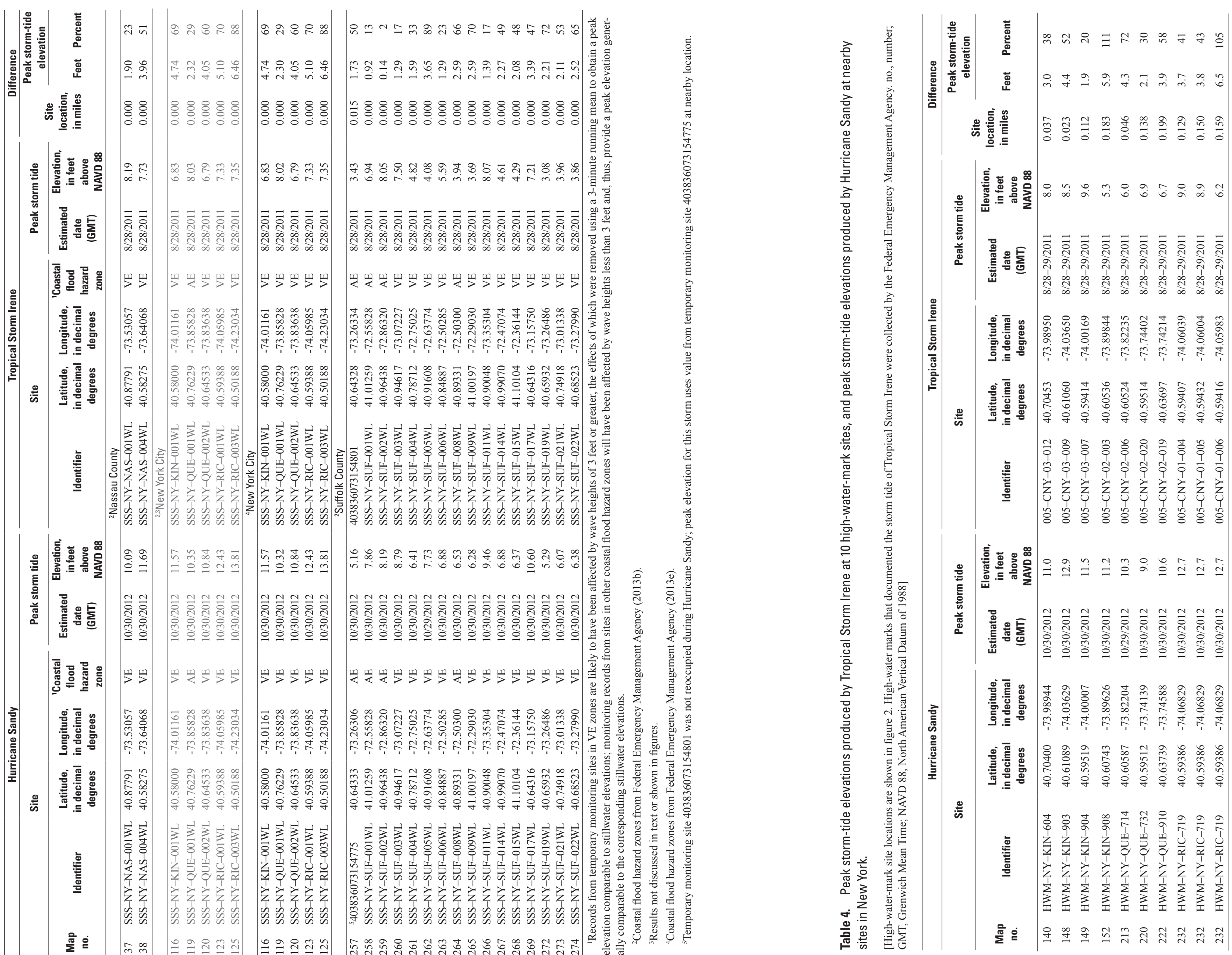

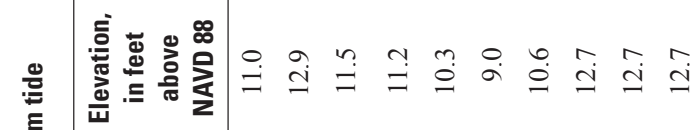

产

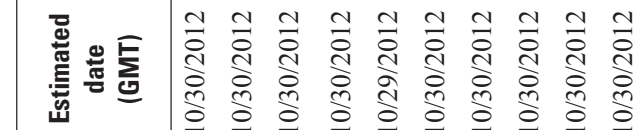

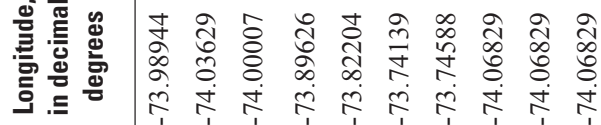

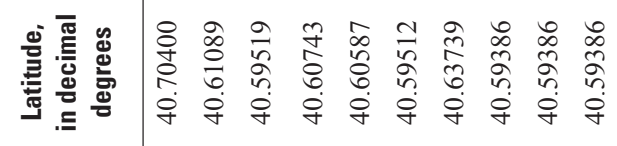

$\stackrel{\circ}{\frac{0}{5}}$

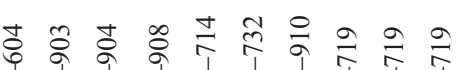

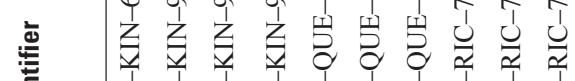

尊咅

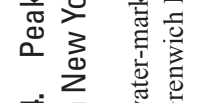

竞:

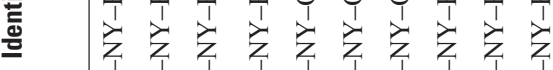

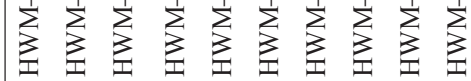

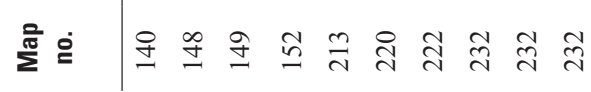



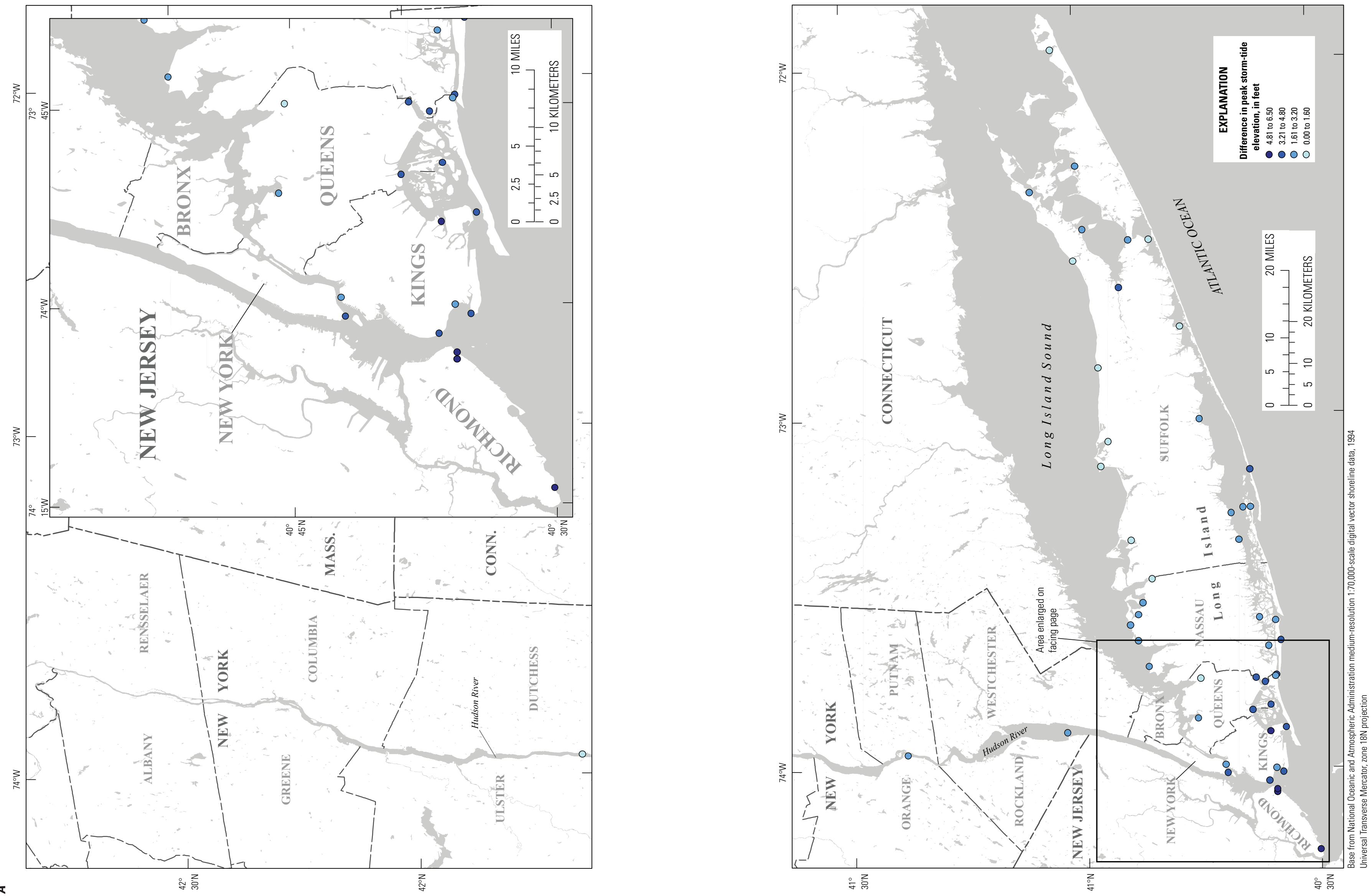

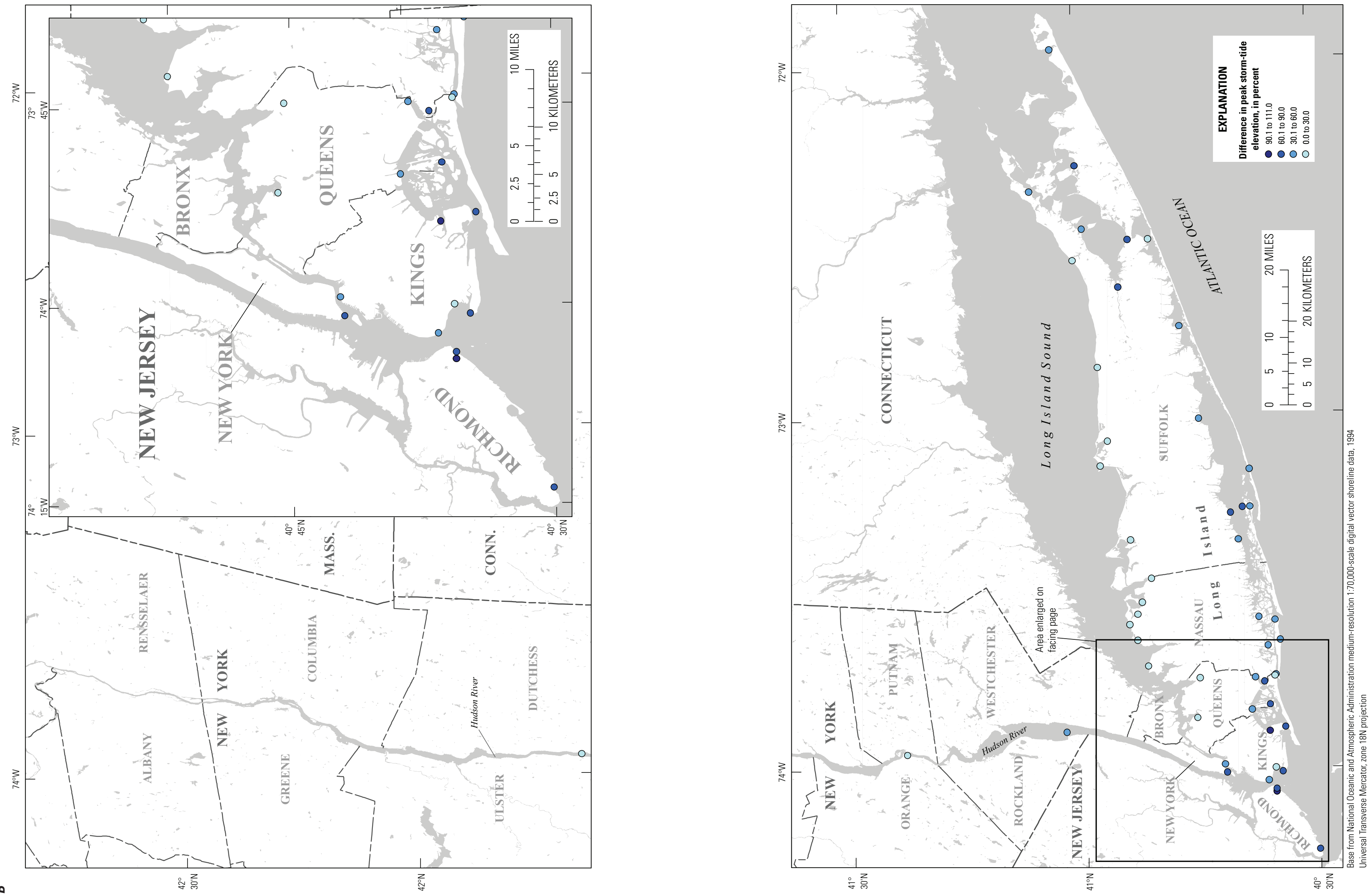

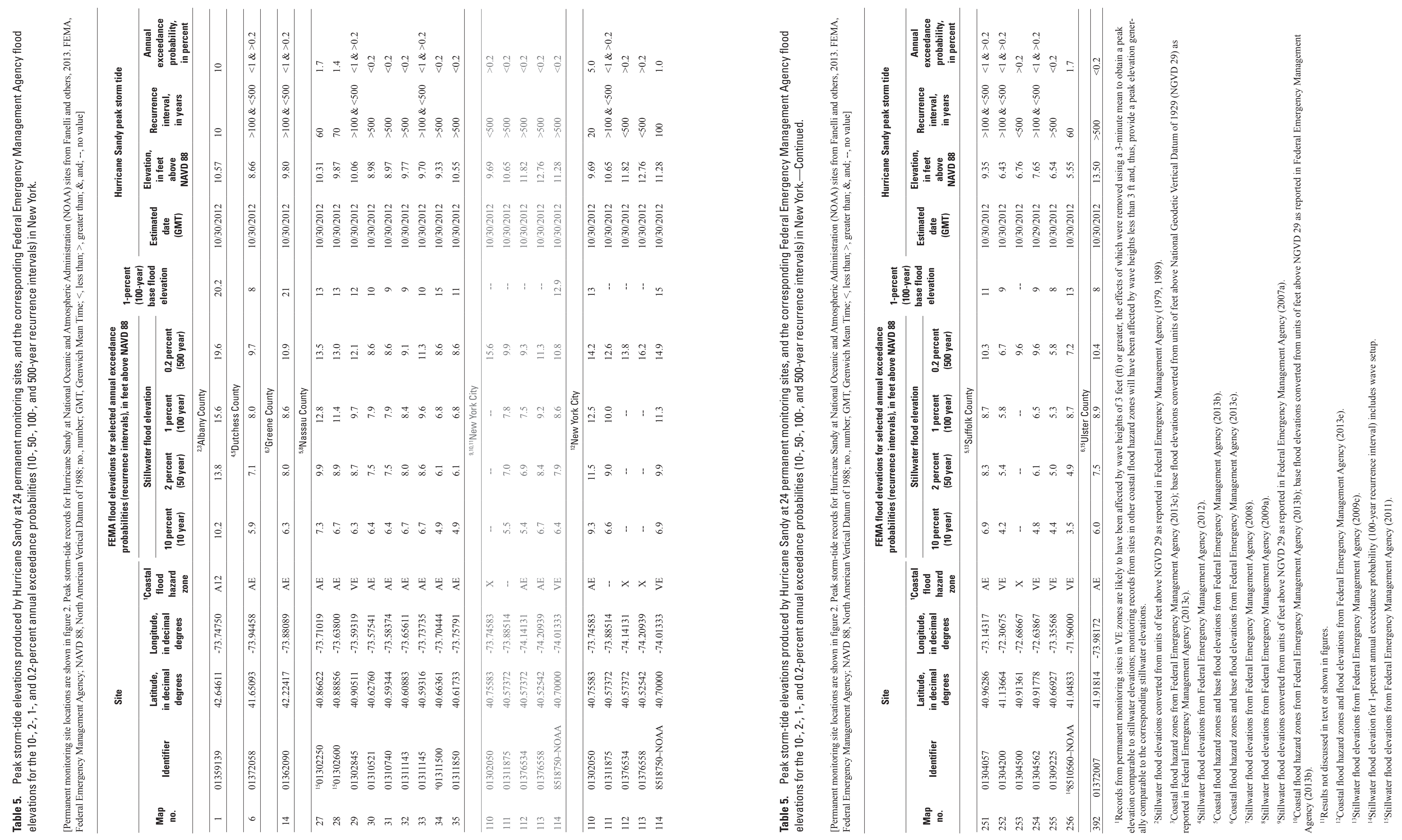

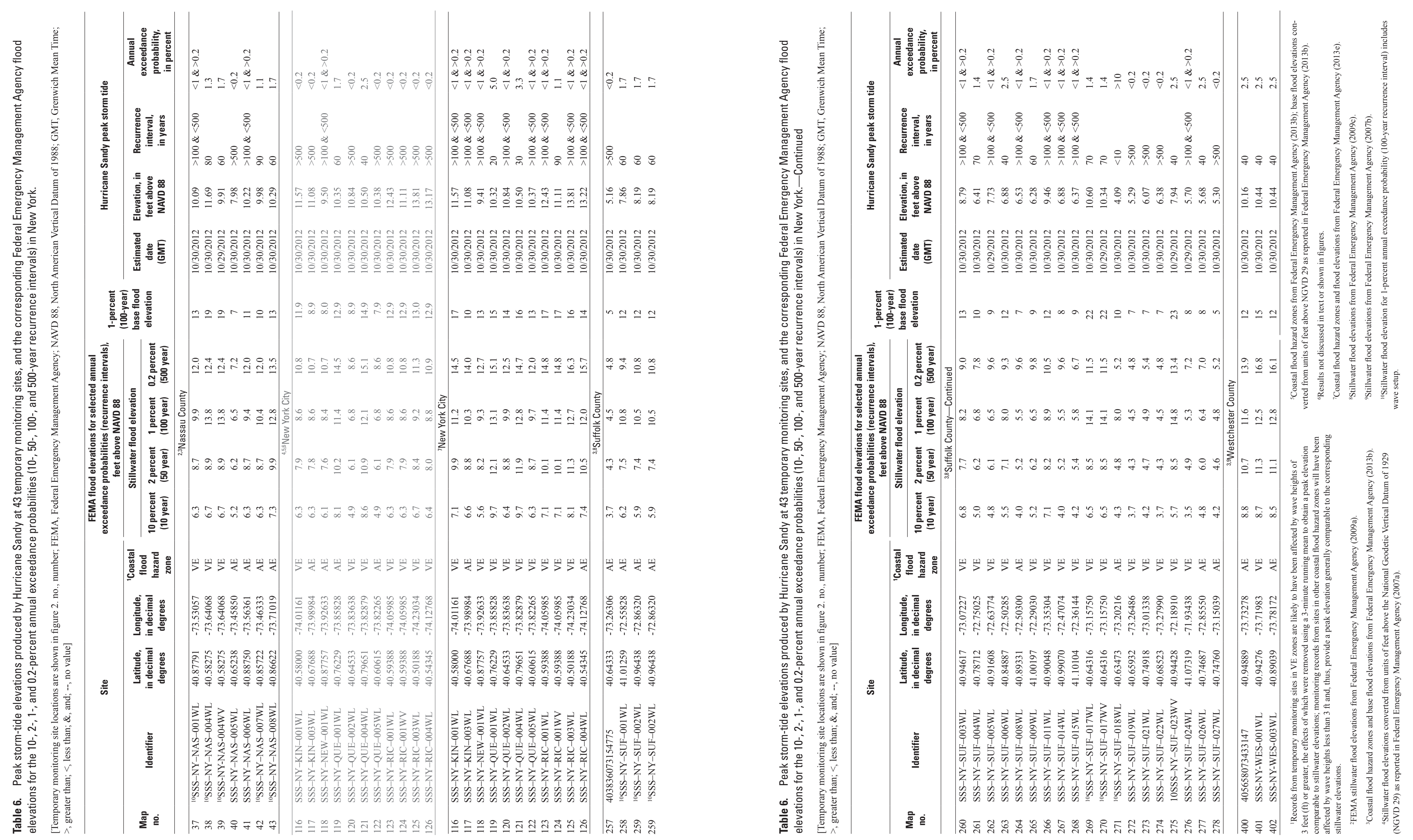

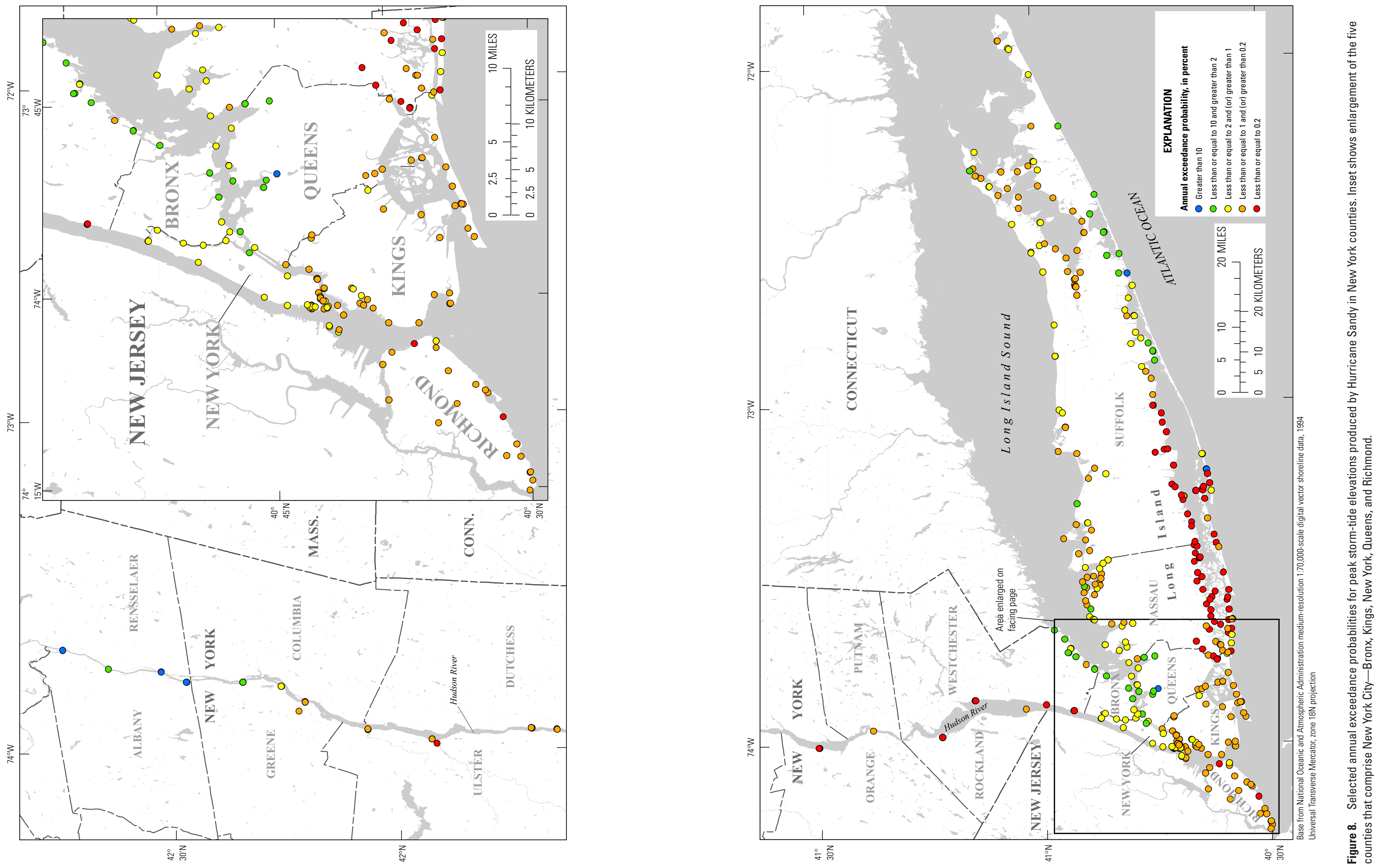


\section{Storm Surge}

Data from selected permanent monitoring sites in the USGS network and from sites in the NOAA network document Hurricane Sandy's storm surge, calculated as the difference between the observed water level and normal (predicted astronomical) tide level. Calculations of this residual water leve were performed to assess the storm-surge magnitude associated with the peak storm tide, and the magnitude and timing of peak storm surge, for these sites in the two networks.

Storm-Surge Magnitude Associated With Peak Storm Tide

The storm-surge magnitudes associated with the peak storm tides produced by Hurricane Sandy at 18 permanen monitoring sites in New York are provided in table 8 and figure $9 \mathrm{~A}$. Most magnitudes of the storm surge associated with the peak storm tide were greater than about $7.8 \mathrm{ft}$; most of these are from sites in Albany County, along the Atlantic Ocean shore of Nassau County, and in New York City. The maximum storm-surge magnitude associated with the peak storm tide was $9.43 \mathrm{ft}$ at permanent monitoring site 8519483 (map number 115) in New York City. The minimum stormsurge magnitude associated with the peak storm tide was $5.24 \mathrm{ft}$ at permanent monitoring site 8510560 (map number 256) in Suffolk County near the extreme eastern tip of Long Island.

Magnitude and Timing of Peak Storm Surge

The magnitude and timing of the peak storm surge produced by Hurricane Sandy at 18 permanent monitoring sites in New York are listed in table 8; the magnitudes of the peak storm-surge from this storm at these sites are shown in figure $9 B$. Most magnitudes of the peak storm surge were greater than about $8.3 \mathrm{ft}$; nearly of these are from sites along the Long Island Sound shores of Nassau and Suffolk Counties and in New York City. The maximum magnitude of the peak storm surge was $12.65 \mathrm{ft}$ at permanent monitoring site 8516945 (map number 36) along the Long Island Sound shore of Nassau County. The minimum magnitude of the peak storm surge was $5.89 \mathrm{ft}$ at permanent monitoring site 8510560 (map number 256) in Suffolk County near the extreme eastern tip of Long Island.

Of the 18 permanent monitoring sites in table 8 , the peak storm surge arrived within 36 minutes of the time of peak storm tide at 8 sites ( 44 percent), all of which are along the Atlantic Ocean shore of Nassau County and in New York City; phase with the astronomical tide-generally coinciding with normal high tide - at these locations (Schubert and Busciolano, 2013). In contrast, the peak storm surge preceded the time of peak storm tide by 90 minutes or more at 9 of 18 sites (50 percent); these sites are all in Albany County, along the Long Island Sound shore of Nassau County, and in Suffolk County. The peak storm surge followed the time of peak storm tide by 114 minutes at the one remaining site, which is in Suffolk County at the head of an estuary on eastern Long ssland. In the two latter cases, the condition resulted from peak stom surges artiving ont of phase with the astronomical sites (Sch or and Buscion 2013), all of which a inese of the New York Bight.

\section{Extent of Storm-Tide Inundation}

Comparisons were made between selected maps of the extents of storn-tide ind dation from Hurricane Sandy that from the ped for data Tites. The com HAZUS (Federal Emergency Manasement Agency, 2013d) flood loss analyses depicted for three different extent of storm-tide inundation from Hurricane Sandy. These depictions include a (1) pre-storm mapping of inundation extent; (2) November 11,2012, mapping of inundation extent; and (3) February 14,2013, mapping of inundation extent (Austen K. Cutrell, Federal Emergency Management Agency, written commun., 2013)

\section{Mapping of Inundation Extent}

The final, pre-storm mapping of inundation exten from Hurricane Sandy, as indicated in a 30-meter (m) resolution NHC Sea, Lake, and Overland Surges from Hurricanes (SLOSH) model (National Hurricane Center, 2013c) hindcast product dated October 31, 2012, is shown in figure $10 A$. Figure $10 B$ shows the November 11,2012 , mapping of inundation extent from Hurricane Sandy, as indicated in a FEMA interim high-resolution (3-m) product that was based on USGS data avaliable from storm landfall throug November 11, 2012. The February 14,2013 , mapping of inundation extent from Hurricane Sandy, as indicated in a FEMA final high-resolution (3-m) product based on USGS data available from storm landfall through February 14, 2013 , is shown in figure 10C. A visual comparison of the three map (fig. 10) shows that small differences in inundation extent are locally apparent, however, more meaningful comparisons may be made using the results of HAZUS flood loss analyses for the mapped inundation extents.

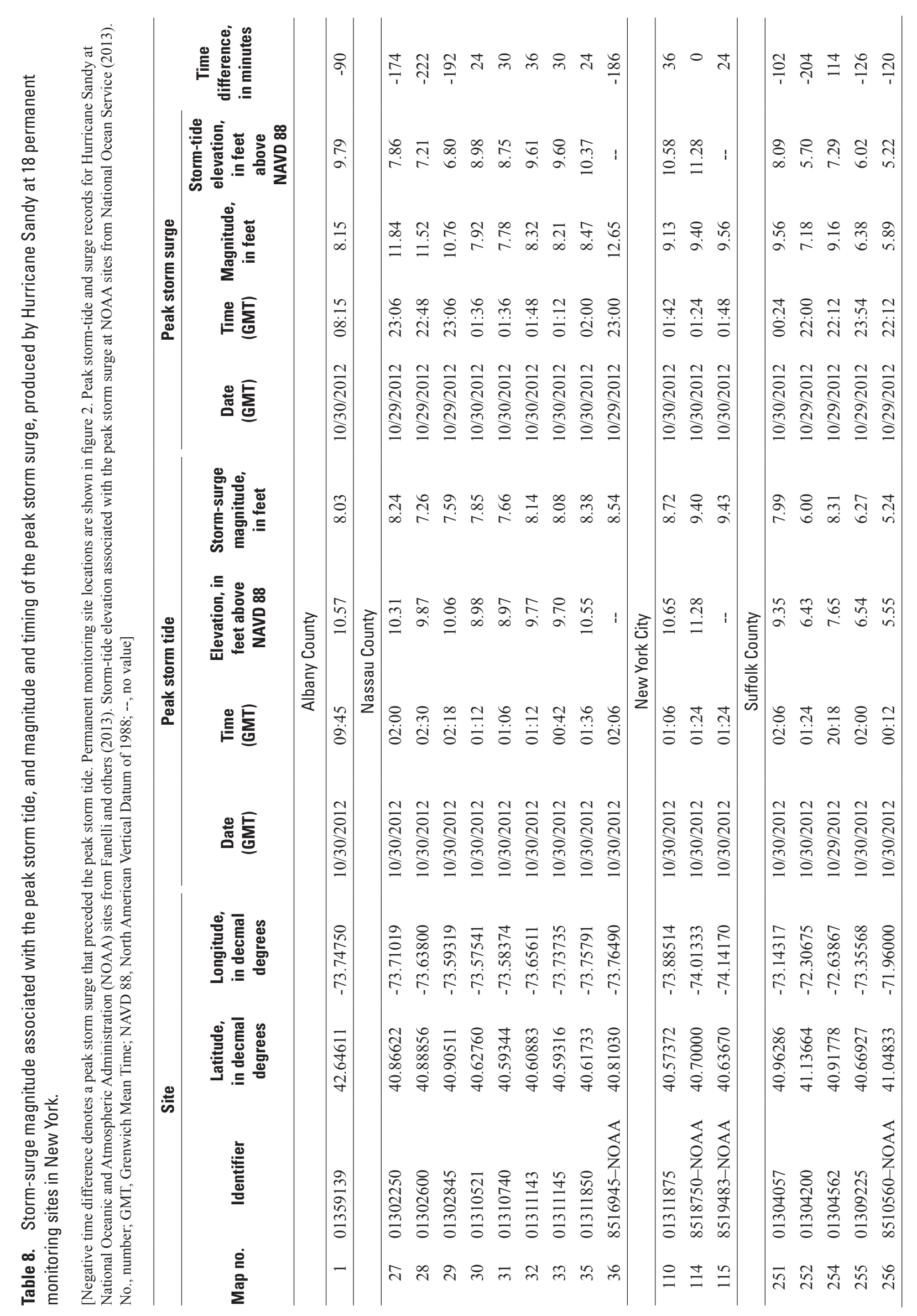



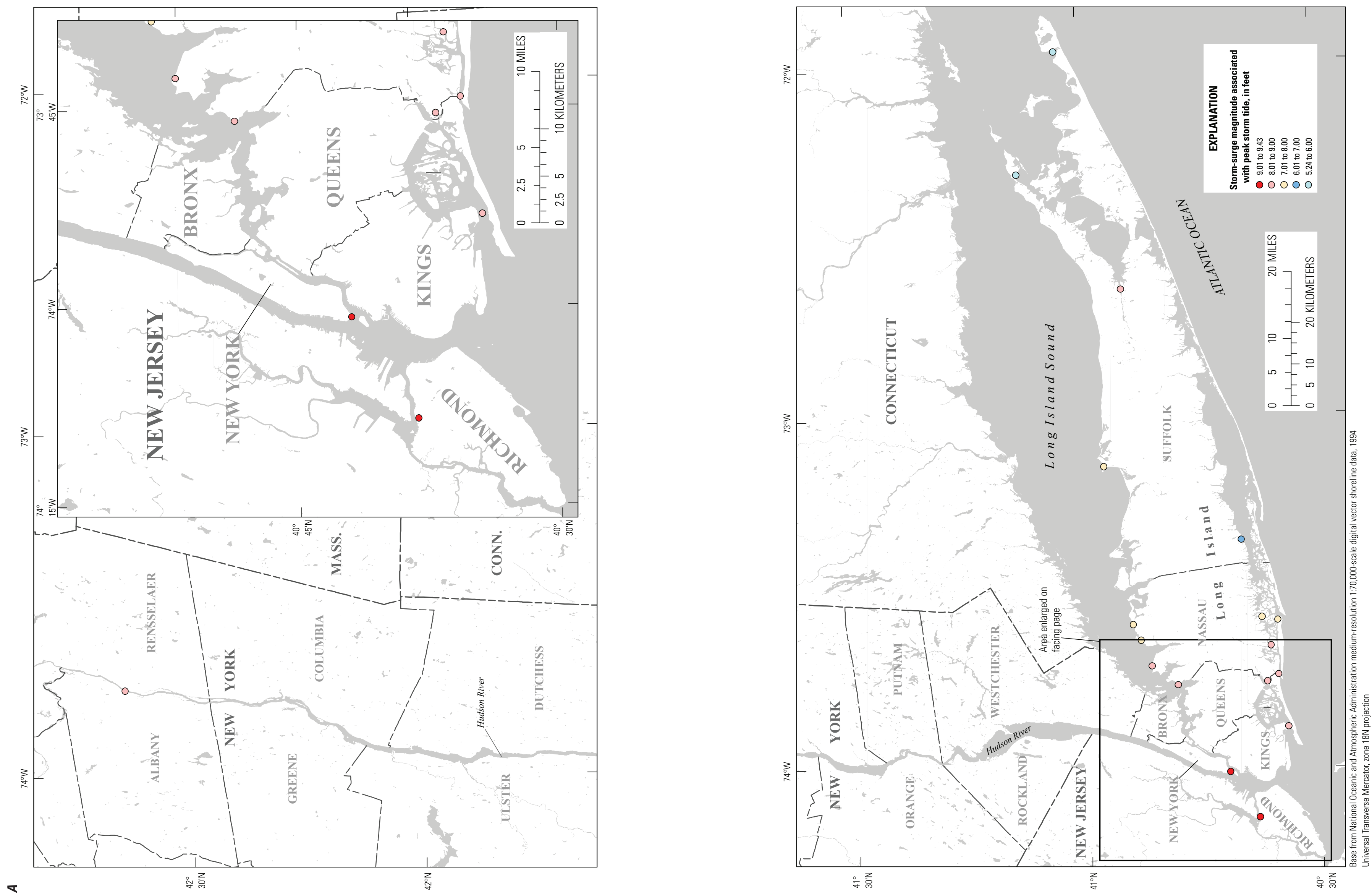

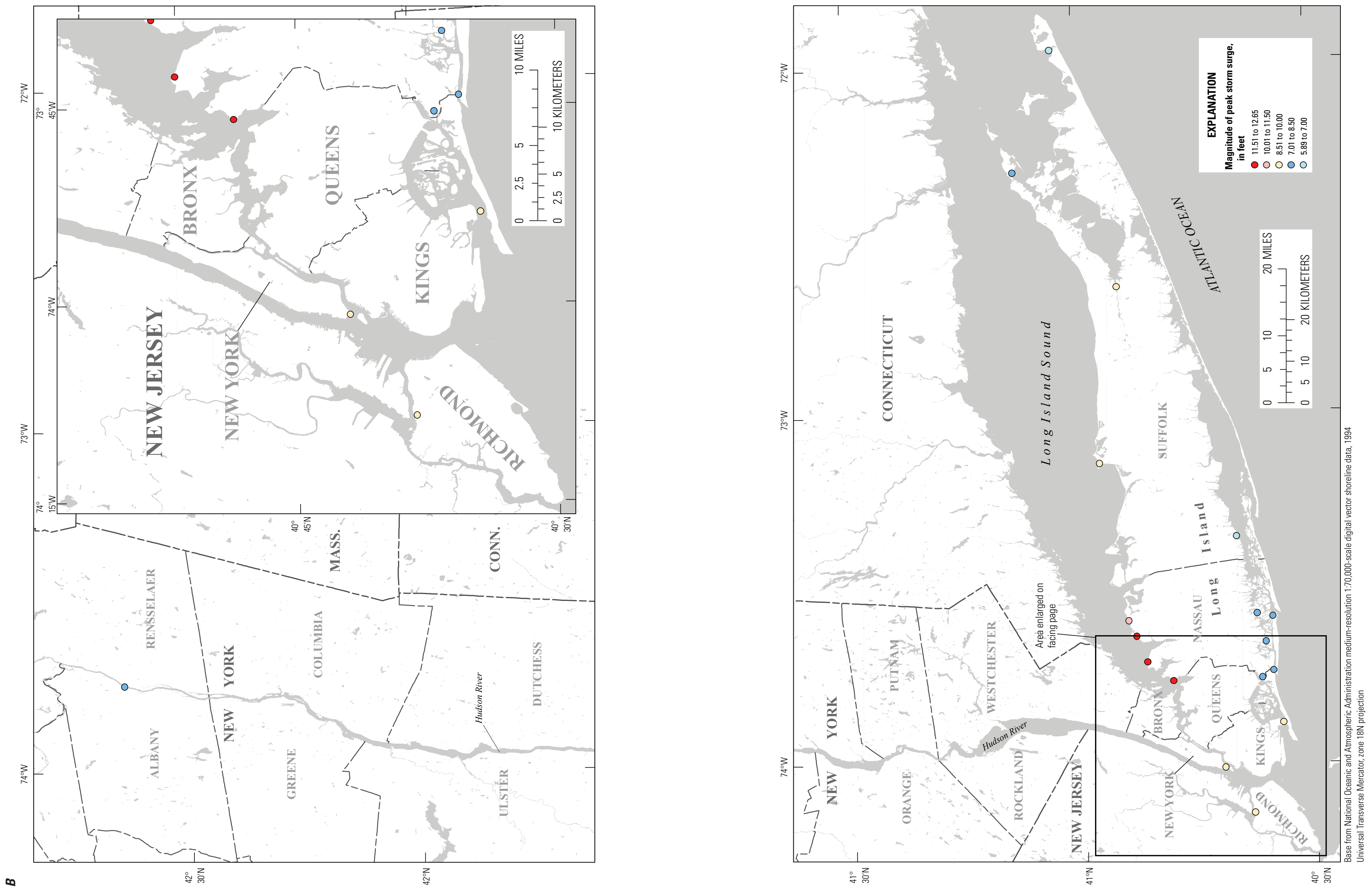

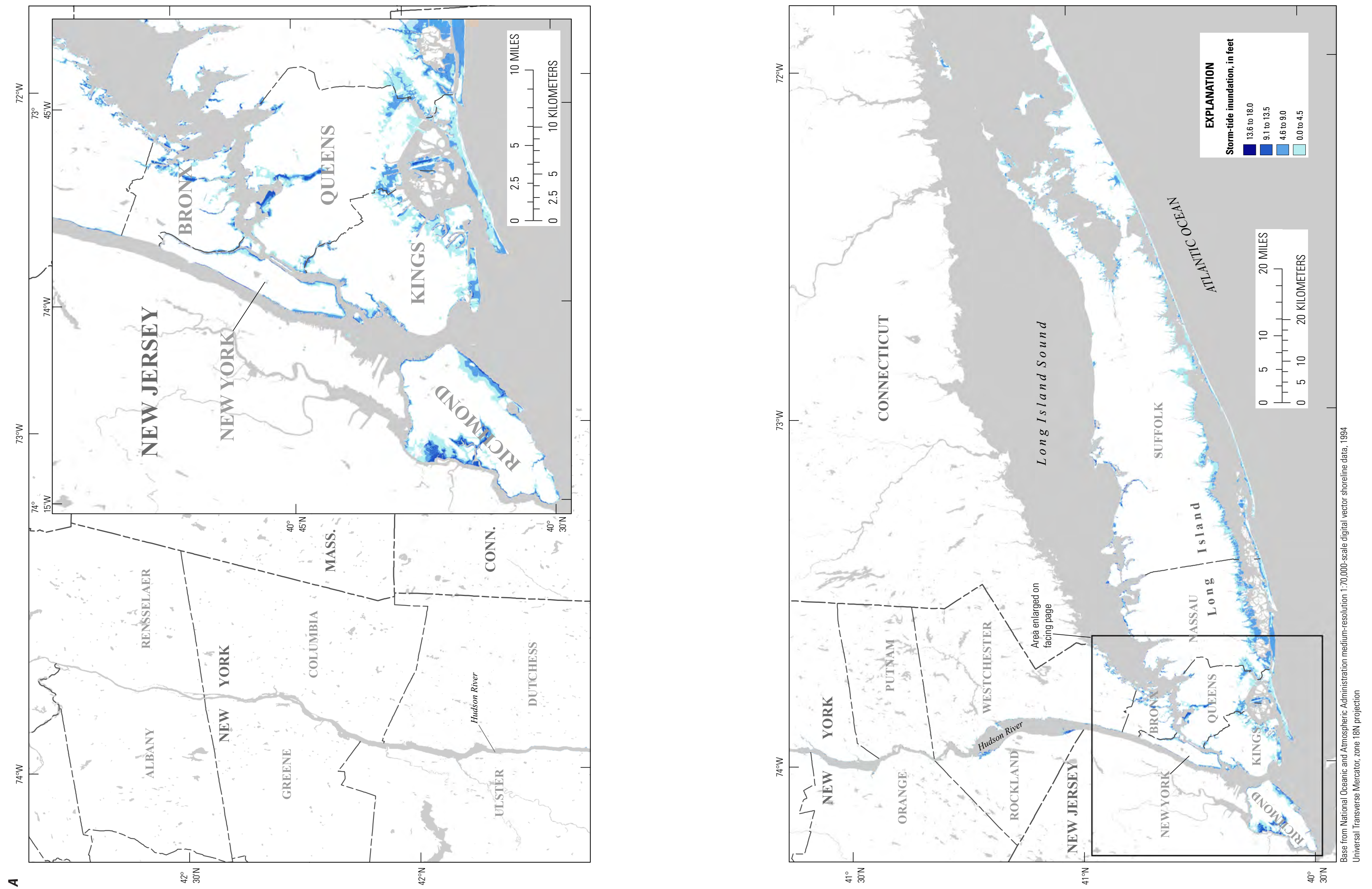

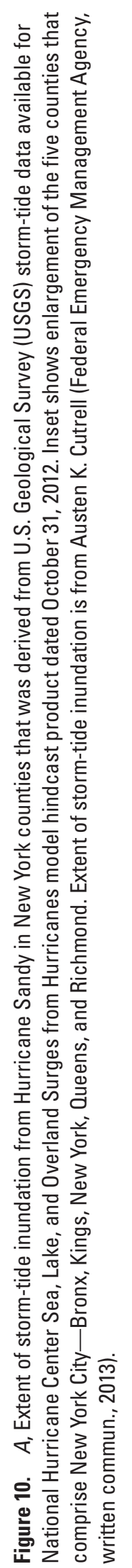



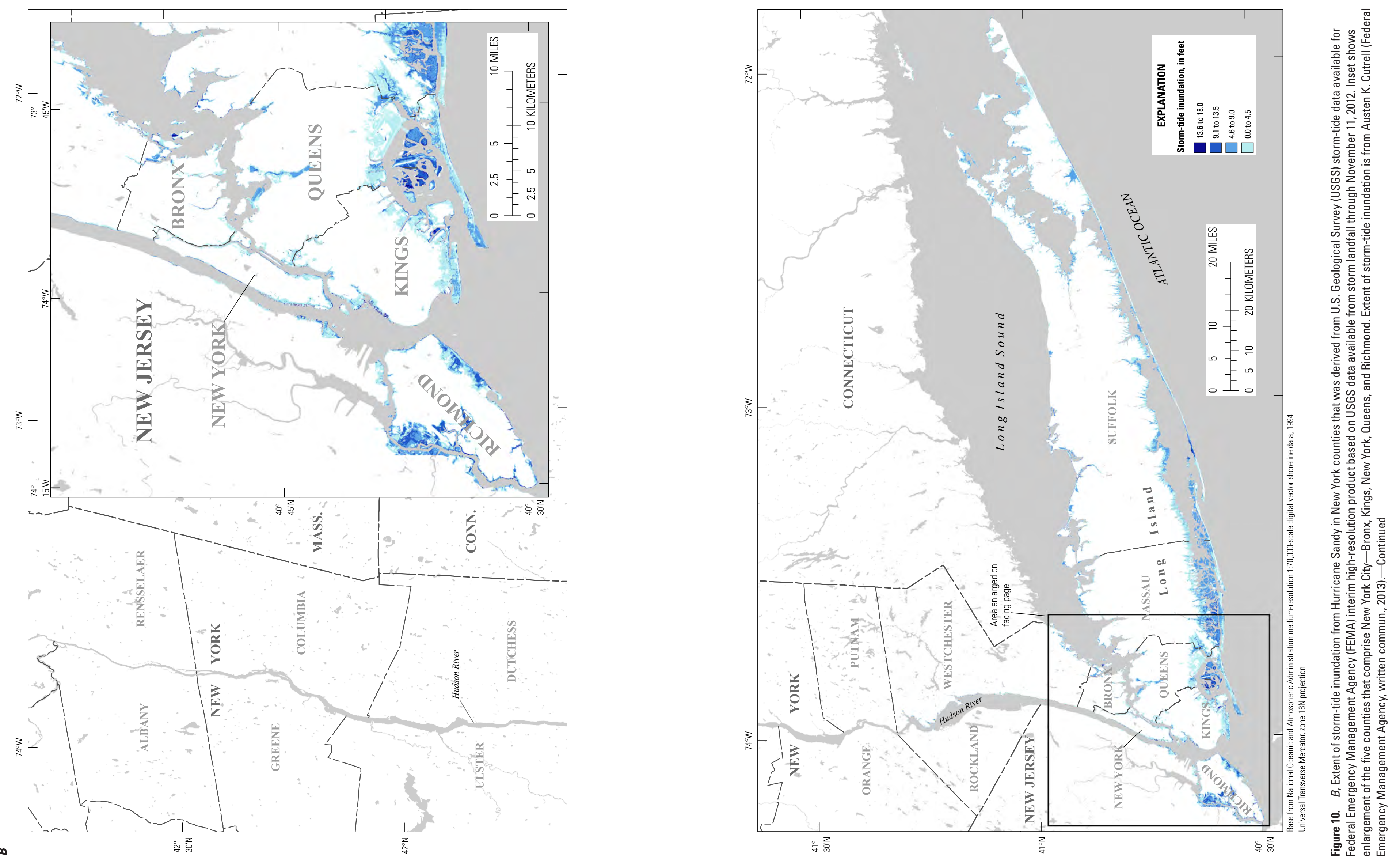

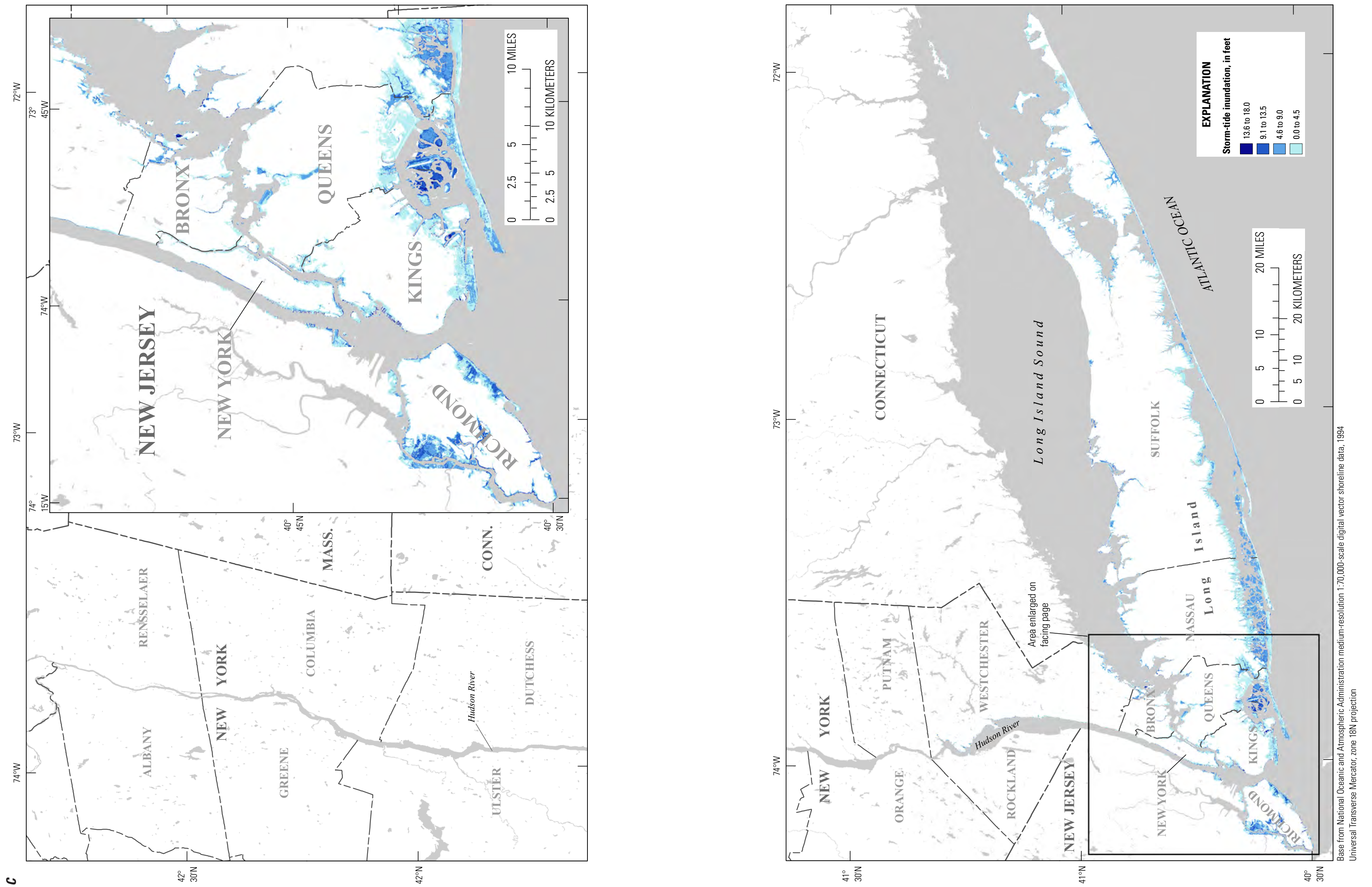

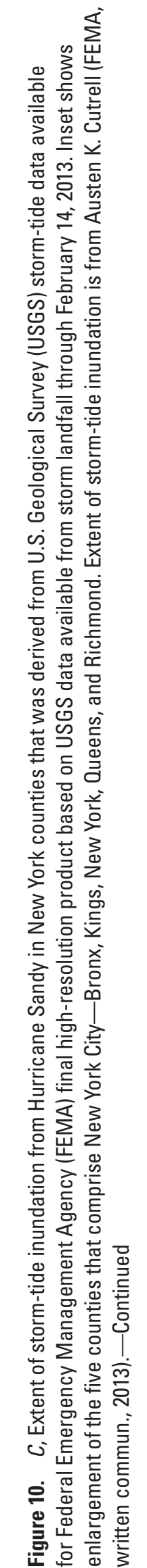




\section{HAZUS Flood Loss Analyses}

HAZUS is FEMA's "nationally applicable standardized methodology that contains models for estimating potential losses" from floods and other disasters; through use of geographic information system (GIS) technology, HAZUS enables the physical, economic, and social effects of disaster to be estimated (Federal Emergency Management Agency, 2013d). Results of HAZUS building stock flood loss analyse performed for New York counties are mapped for the three extents of inundation from Hurricane Sandy in figure 11; the losses for the three different storm-tide inundation extents are graphed by date in figure 12 . The results consist of depictions of estimated total building stock losses for the pre-storm (October 31, 2012) mapping of inundation extent; November 11, 2012, mapping of inundation extent; and February 14, 2013, mapping of inundation extent (fig. 10A,

$10 B$, and $10 C$, respectively, and fig. 12 .

The depictions of estimated total building stock losses document how differing amounts of available USGS data affect the resolution and accuracy of storm-tide inundatio extents. Estimated losses for October 31, 2012, (fig. 11A) were derived from an inundation extent (fig. 10A) that was based on essentially no data from the temporary monitoring
sites or HWM sites. Estimated losses for November 11, 2012, (fig. 11B) were derived from an inundation extent (fig. 10B) produced after most of the temporary sensor data became available but before most of the HWM sites were surveye Estimated losses for February 14, 2013, (fig. 11C) were derived from an inundation extent (fig. 10C) produced after all data from the temporary monitoring sites and HWM sites had become available.

Overall, the depictions indicate that estimated losses from Hurricane Sandy for all building stock are consisten higher for coastal conties, paticulaly those along the Atlantic Ocean shore (fig. 11), tha for U13) ing stock losses range from $\$ 380$ million to $\$ 5.9$ billion for ing stock lo ofs range for $\$ 330$, $\$ 23$ billion for all New York counties (fig. 12). The age gate HAZUS loss assessments for all New York coggehighest for the analyses made using the October 31,2012 inundation data; substantially lower for the analyses mi2, using the November 11,2012 , inundation data; and lower for the analyses made using the February 14, 2013 , inundafor the analyos trend also appears in the results for Nassau New York counties; however, the results for other counties show mixed trends.

Estimated total building stock losses from Hurrican Sandy for the three storm-tide inundation extents were subtracted from one another to create graphs from dataset of differences, which are shown in figure 13. The differences datasets are referred to by the dates of the inundation extents used in the HAZUS analyses-November 11, 2012, minus October 31, 2012 (fig. 13A), February 14, 2013, minus October 31, 2012 (fig. 13B), and February 14, 2013, minus November 11, 2012 (fig. 13C). These datasets indicate ther are substantial differences between HAZUS loss estimates for analyses done using the three inundation extents. Figure 13 clearly shows the differences resulting from the quality of the inundation extent, which, in turn, is largely determined by the availability of USGS storm-tide data. The differences (expressed using absolute values) are as high as $\$ 4.6$ billion for individual counties, while aggregate total (fig. 12) Th the

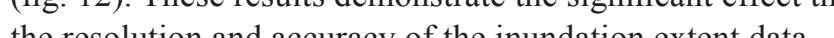
have on the HAZUS ary or the in thesolution monitoring network deployment and HWM flaging and veying compign, the cost of this deployment and campaign seems more than justified by the substantial improvement in final loss estimates. The value of these findings for informing future post-storm recon insurance claims are considerable

\section{Summary and Conclusions}

The hybrid cyclone nor'easter known as Hurricane Sandy affected the mid-Atlantic and northeastern coastline of the United States during October 28-30, 2012, producin northeast-to-southeast winds of tropical-storm strength (39 to 73 miles per hour [mi/hr]) that gusted to greater than hurricane strength (greater than $73 \mathrm{mi} / \mathrm{hr}$ ) and caused extensive coastal flooding and beach erosion. Prior to storm landfall, the U.S. Geological Survey (USGS) deployed a temporary monitoring network from Virginia to Maine of water-level and barometric pressure sensors to continuously tide and the tide and coastal flooding gonerated by Hurricane Sandy and Nation (NOAA) netwo of perato document between the observed water level and nomal (predicted astronomical) tide level. Continuous data from these networks were greatly supplemented by an extensive poststorm high-water-mark (HWM) flaging and surveying campaign from November to December 2012. The tempor monitoring network deployment and HWM flaging and surveying campaign were undertaken as part of a coordinated Federal emergency response as outlined by the Stafford Act. (42 U.S.C. 5121 et seq.) under a directed mission assionment by the Federal Emergency Management Agency (FEMA). The need for information that assists in the analysis of flood damages and future flood mitigation efforts in New York prompted the current analysis of Hurricane Sandy by the USGS under this FEMA mission assignment.

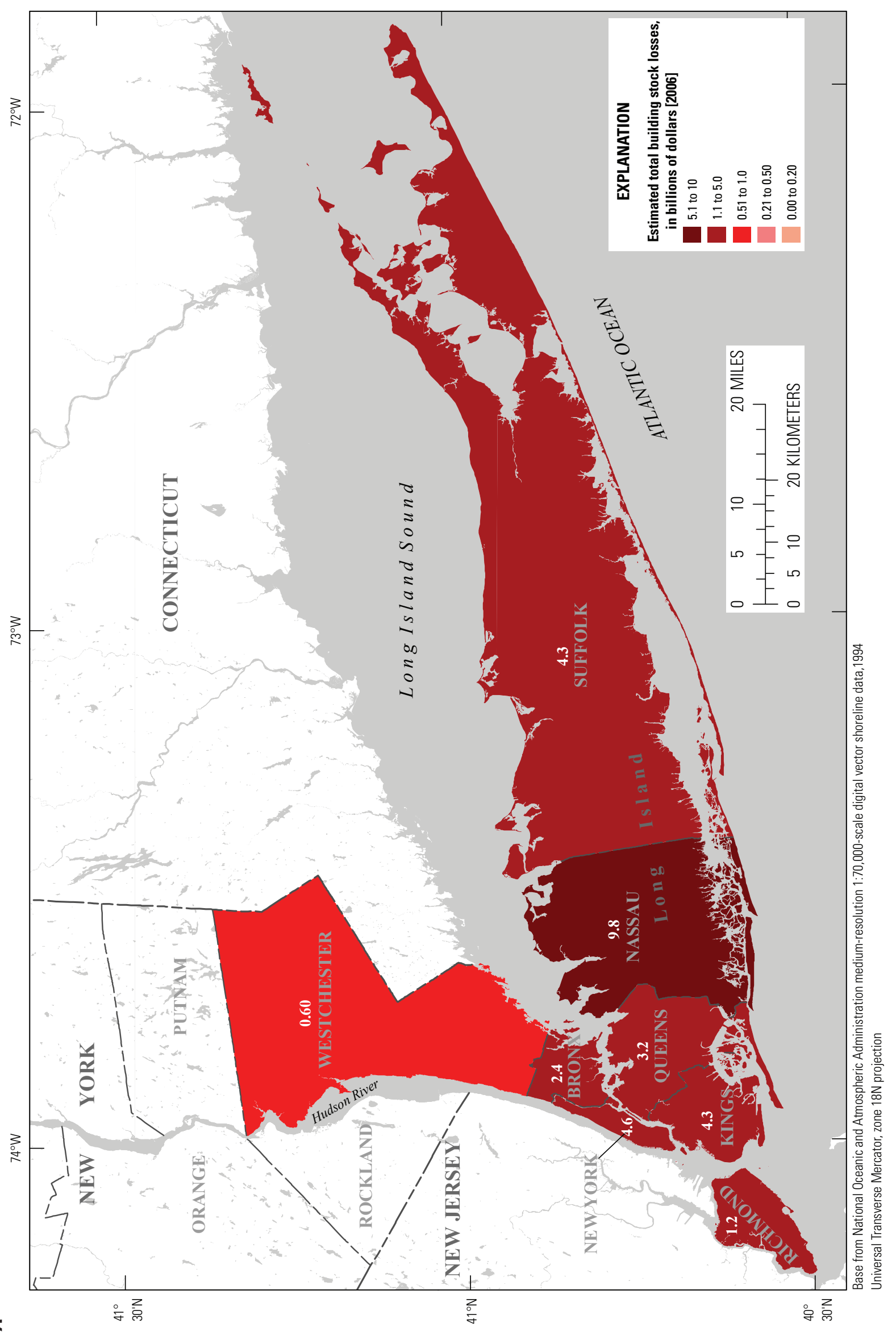


44 Analysis of Storm-Tide Impacts From Hurricane Sandy in New York

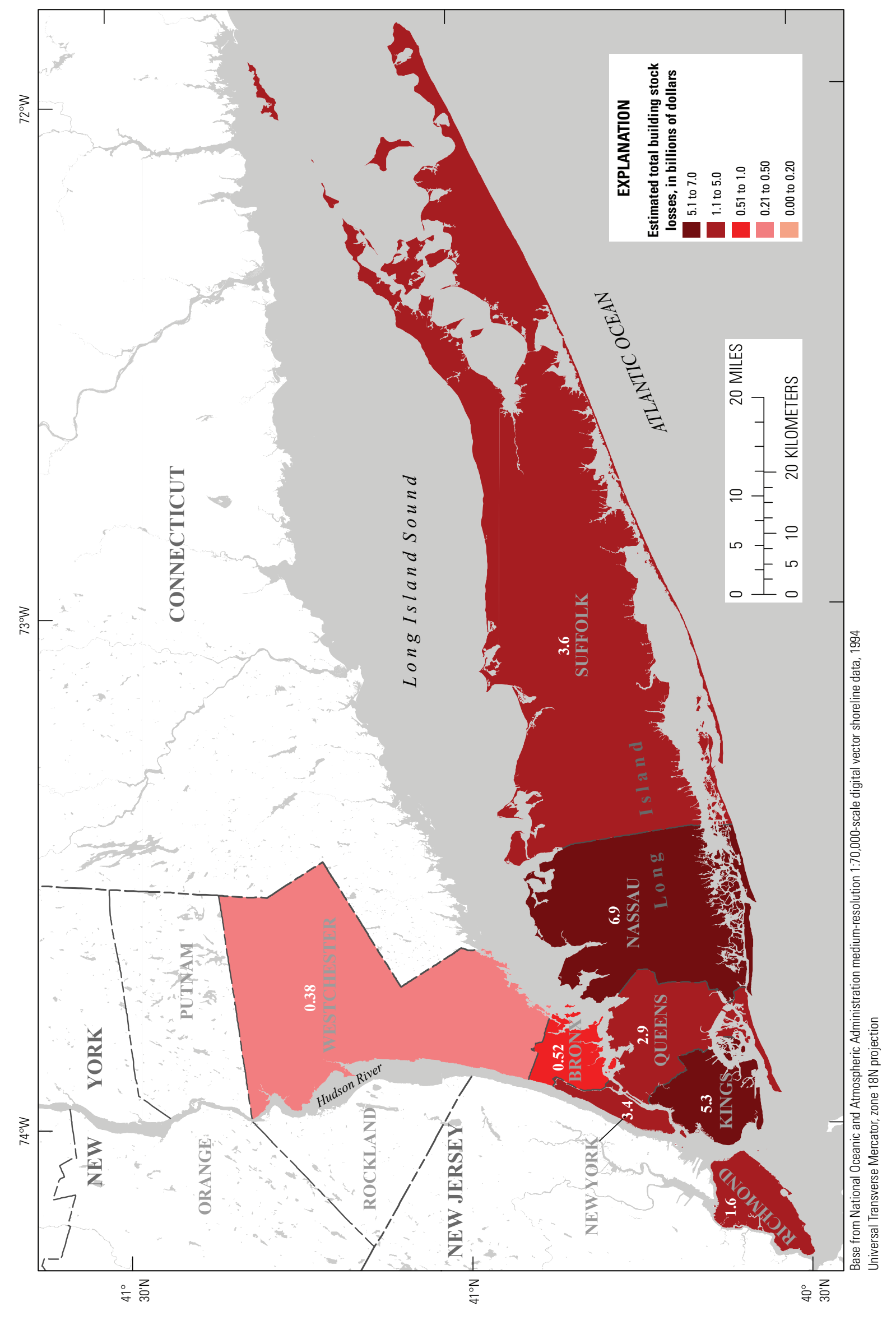

Summary and Conclusions

45
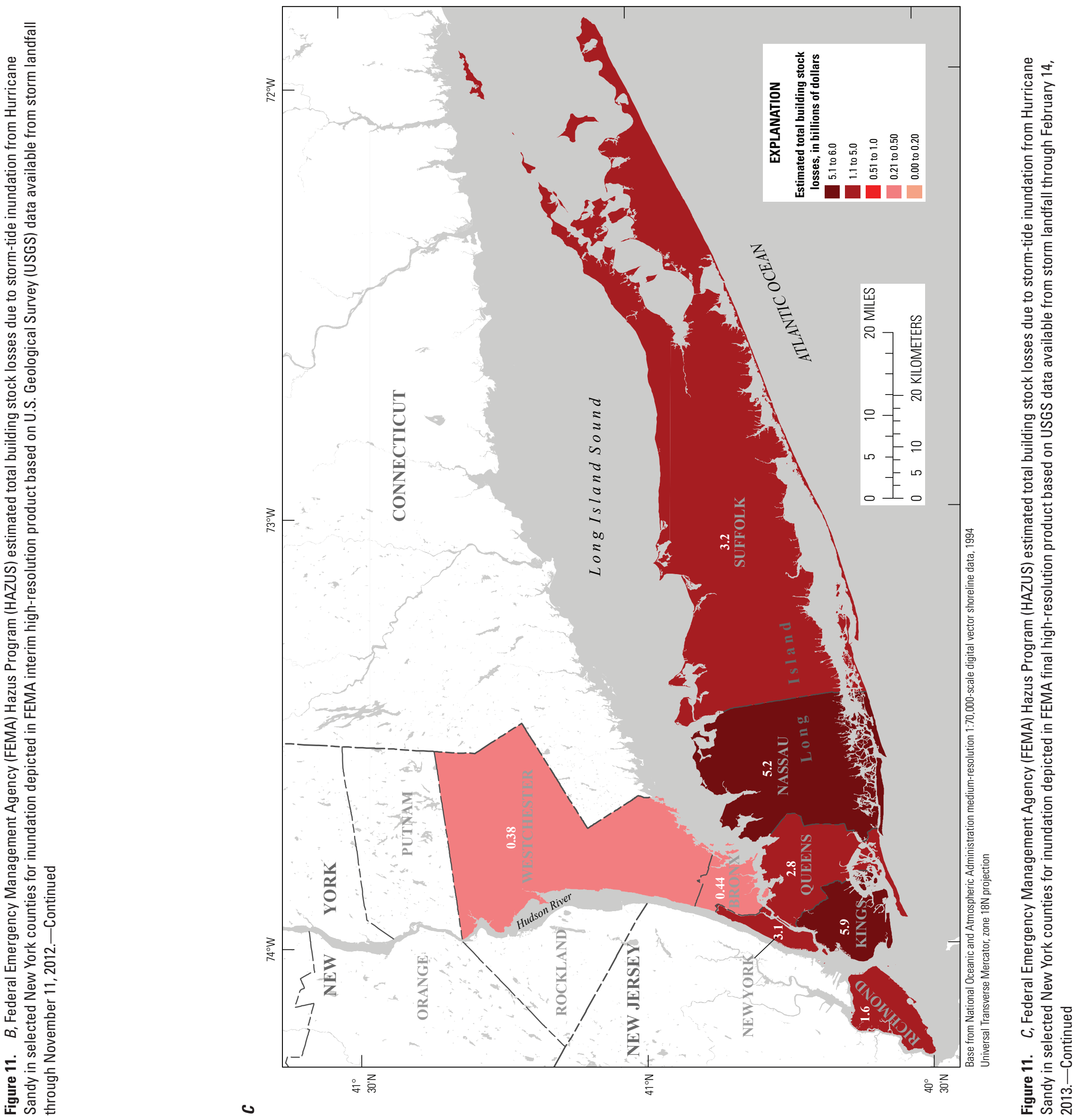


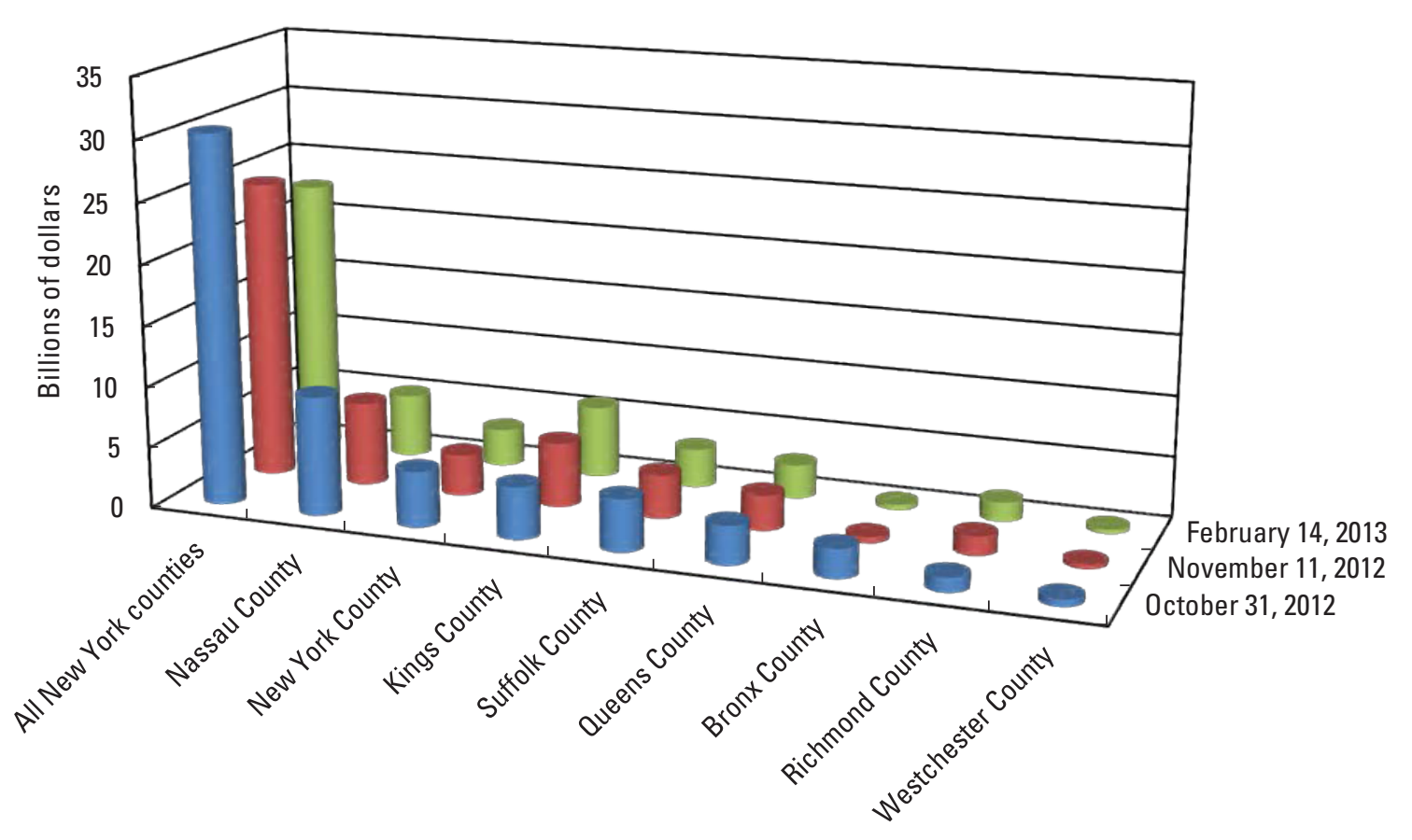

Figure 12. Federal Emergency Management Agency (FEMA) Hazus Program (HAZUS) estimated total building stock losses due to storm-tide inundation from Hurricane Sandy in selected New York counties for inundation depicted in National Hurricane Center Sea, Lake, and Overland Surges from Hurricanes model hindcast product available from storm landfall through November 11, 2012, and FEMA final high-resolution product based on USGS data available from storm landfall through February 14, 2013.

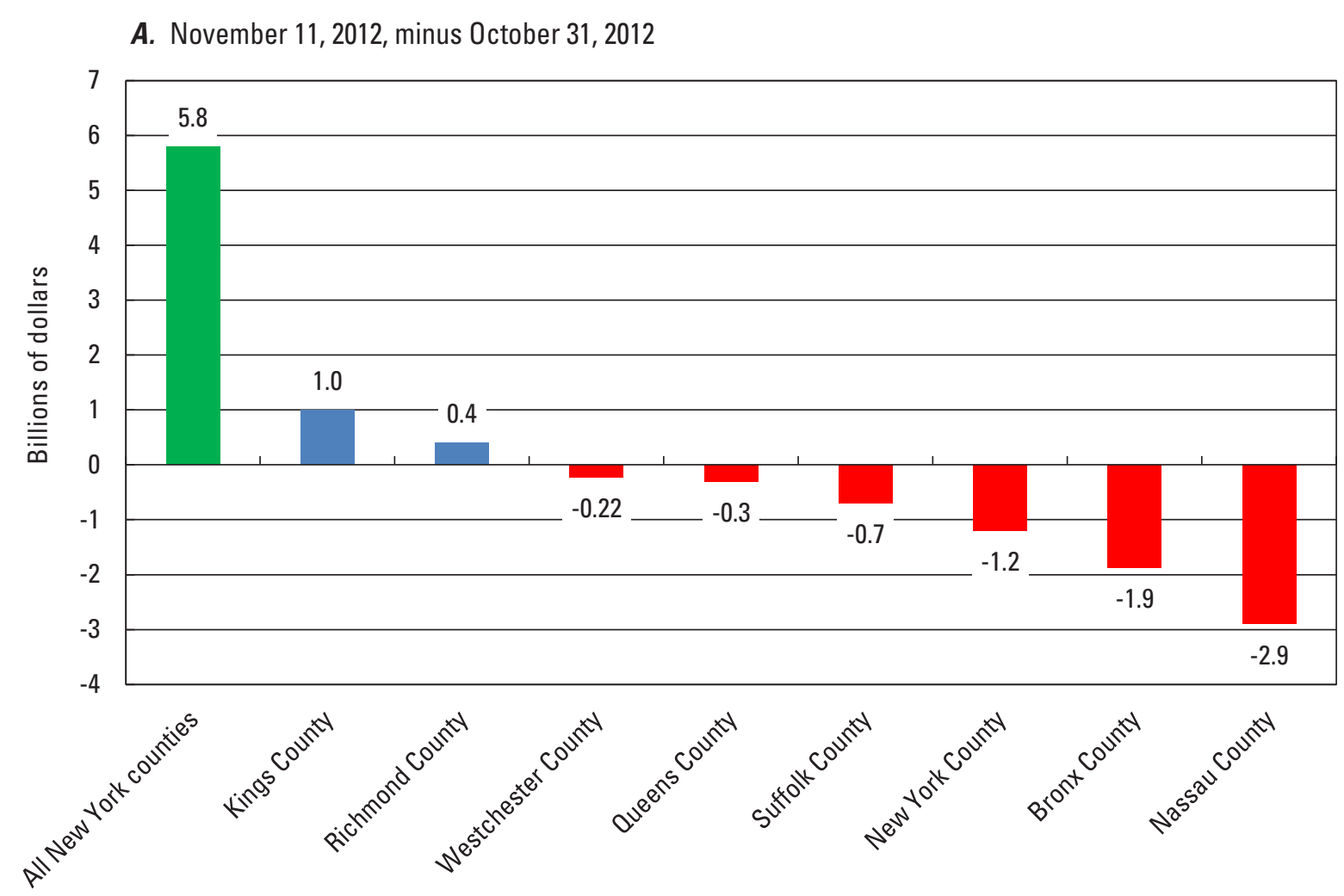

B. February 14, 2013, minus 0ctober 31,2012
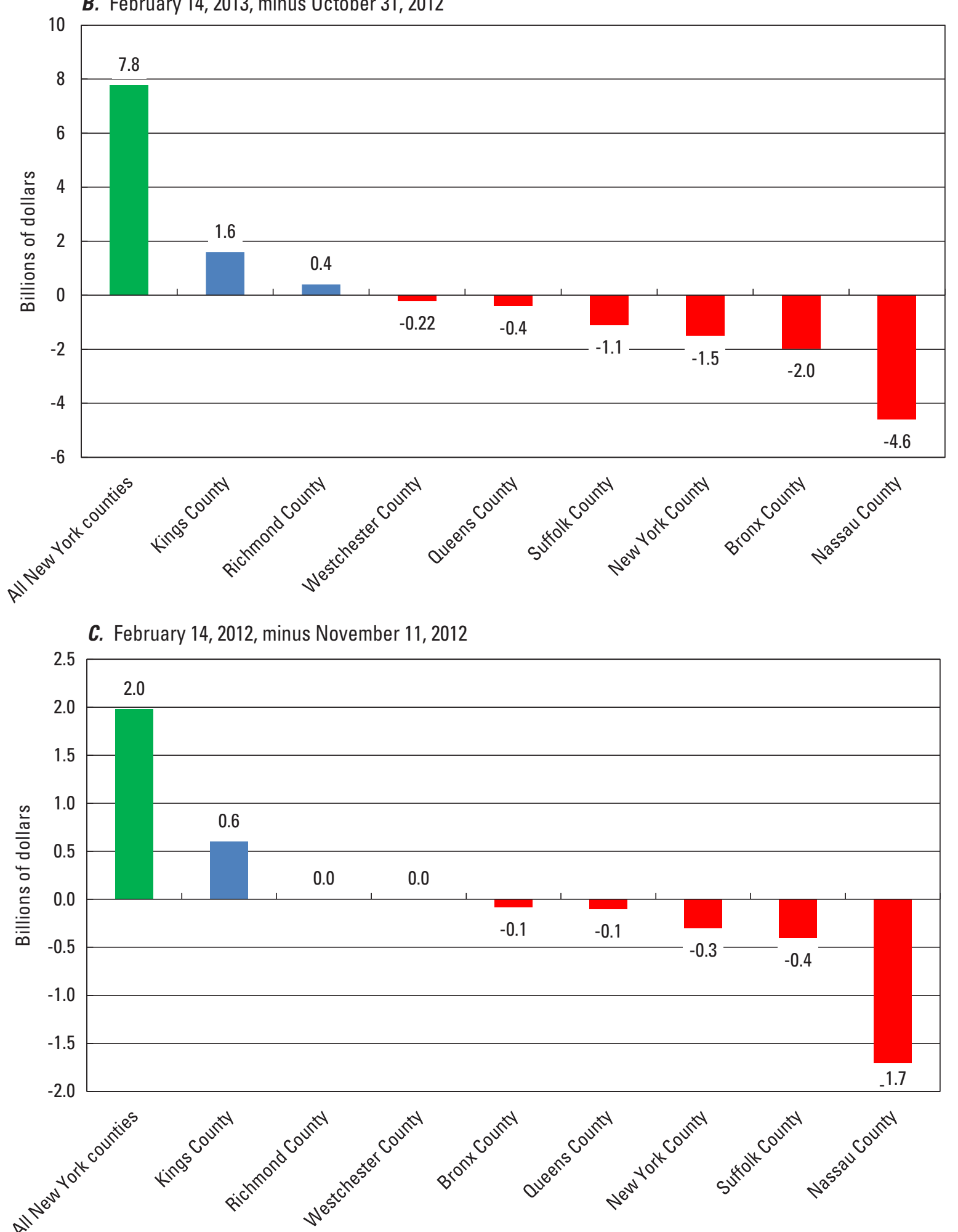

Figure 13. Differences between Federal Emergency Management Agency (FEMA) Hazus Program (HAZUS) estimated total building stock losses due to storm-tide inundation from Hurricane Sandy in selected New York counties for inundation depicted in National Hurricane Center National Hurricane Center Sea, Lake, and Overland Surges from Hurricanes model hindcast product dated October 31, 2012, FEMA interim high-resolution product based on U.S. Geological Survey (USGS) storm-tide data available through November 11, 2012, and FEMA final high-resolution product based on USGS storm-tide data available through February 14, 2013. A, November 11, 2012, minus 0ctober 31 , 2012, B, February 14, 2013, minus October 31, 2012, and C, February 14, 2013, minus November 11, 2012. Blue and red shading denotes positive and negative values, respectively. Green shading denotes absolute values. 
Hurricane Sandy was the 18th named storm and 10th hurricane of the 2012 Atlantic hurricane season. The extremely large fetch of tropical-storm force winds circulating aroun Hurricane Sandy, combined with its anomalous track, piled large amounts of ocean water, over multiple tidal cycles, north and west of the center of counterclockwise circulation. Thi onshore flow was funneled into the New York Bight- the large embayment formed by the Atlantic coastline of Long Island and northern New Jersey — and inland through the many tho the Hudson River to the head-of tide at the Fed to in Troy.

The analysis of storm-tide impacts focused on three
. distinct but related aspects of coastal flooding produced by Hurricane Sandy, including flooding inland along the tidal reach of the Hudson River. These aspects are (1) compariso
of Hurricane Sandy peak storm-tide elevations with those of Hurricane Sandy peak storm-tide elevations with tho
of historical storms and to annual exceedance probabiliof historical storms and to annual exceedance probabili-
ties; (2) identification of the storm-surge magnitude associat ties; (2) identification of the storm-surge magnitude associa
with the peak storm tide, and magnitude and timing of the peak storm surge; and (3) comparisons of maps of inundation extent that were derived from differing amounts of available sensor and HWM data. Most peak storm-tide elevations from Hurricane Sandy were greater than about 9.5 feet $(\mathrm{ft})$ above North American Vertical Datum of 1988; this level was exceeded at most of the sites in Albany, Nassau, Rensselaer,

and Westchester Counties and New York City.

Peak storm-tide elevations produced by Hurricane Sand were compared with those of historical storms for which dat on substantial coastal flooding are available. These storms include the intense nor'easter of December 11-13, 1992, and Hurricane Irene (August 27-28, 2011), which weakened to a tropical storm before arriving in New York. Peak storm-tide elevations from Hurricane Sandy were higher than those from the December 1992 nor'easter at 24 of 27 sites ( 89 percent) overall. Most differences were greater than about $0.7 \mathrm{ft}$ of 9 percent (above the historical storm tide), with most of these from sites along the Atlantic Ocean shores of Nassau and Suffolk Counties and in New York City. Peak storm-tide elevations from Hurricane Sandy were higher than those from tropical Storm Irene at all sites. Most differences were greater

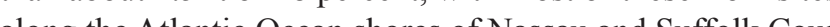
ties, in New York City, and in Rockland County.

Peak storm-tide elevations at the permanent and temporary monitoring sites and the HWM sites were compared wit and 0.2 -percent onnual 100-, and 500-year recurrence intervals). Peak storm-tide elevations from Hurricane Sandy had annual exceedance probabilities of less than or equal to 1 percent and (or) gre than 0.2 percent [recurrence intervals greater than or equalto 100 years and (or) less than 500 years] at a plurality of sites-184 of 413 (45 percent); most of these were from sites in Dutchess, Nassau, Orange, Rockland, Suffolk, and Ulster Counties; New York City; and along the Hudson River shore of Westchester County. Peak storm-tide elevations associated with the minimum annual exceedance probabilities (maximu recurrence intervals) - elevations higher than or equal to the FEMA 0.2-percent (500-year) flood elevation-accounted for 81 of 413 sites ( 20 percent); most of these were along the Atlantic Ocean shore of Nassau and western Suffolk Counties, in Orange and Rockland Counties, and along the Hudson River shore of Westchester County. Peak storm-tide elevation associated with the maximum annual exceedance probability FEMA 10-percent (10-year) flood elevation a than of 10 of 413 sites ( 2 percent); most of these were in Abr only 10 or 413 sites (2 percent); most of .

Data from selected permanent monitoring sites in the used to assess the storm-surge magnitude assorithe peak storm tide and the magnitude and timing of the peak storm surge. Most magnitudes of the storm surge associated with the peak storm tide were greater than about $7.8 \mathrm{ft}$; mos of these are from sites in Albany County, along the Atlantic Ocean shore of Nassau County, and in New York City. Most magnitudes of the peak storm surge were greater than about $8.3 \mathrm{ft}$; nearly all of these are from sites along the Long Island Sound shores of Nassau and Suffolk Counties and in New York City. Of the 18 permanent monitoring sites, the peak storm surge arrived within 36 minutes of the time of peak storm tide at 8 sites ( 44 percent), all of which are along the Atlantic Ocean shore of Nassau County and in New York City; this condition resulted from the peak storm surge arriving in phase with the astronomical tide - generally coinciding with normal high tide - at these locations. In contrast, the peak storm surge preceded the time of peak storm tide by 90 minutes or more at 9 of 18 sites (50 percent); these sites are all in Albany County, along the Long Island Sound shore of Nassa County, and in Suffolk County. In this latter case, the condition resulted from peak storm surges arriving out of phase wit the astronomical tide- nearly coinciding with normal low tide locally - at these sites, all of which are inland of the New York Bight. Understandably, the timing of peak storm surge arival winh respect to local phase of tide ultimately controlled where the most extreme storm-tide levels and coastal flooding by the hi his finding has bearing not only for sites impacted for those sites that the greest sures the wort flooding because of fortuitous timing ding this storm.

Comparisons were made between selected maps of the Content of stom-tide inundation from Hurricane Sundy that were derived from differing amounts of available USGS data from the permanent and temporary monitoring sites and HWM sites. The comparisons were made using the results of FEMA Hazus Program (HAZUS) flood loss analyses depicted for three different extents of storm-tide inundation from Hurricane Sandy. Depictions of estimated total building stock losses document how differing amounts of available USGS data affect the resolution and accuracy of storm-tide inundation extents.
Overall, these depictions indicate that estimated losses from Hurricane Sandy for all building stock are consistently higher for coastal counties, particularly those along the Atlantic Oce shore, than for other New York counties. Using the most accurate results from the final (February 14, 2013) extent of stormtide inundation, estimated total building stock losses range from $\$ 380$ million to $\$ 5.9$ billion for New York counties; tota estimated aggregate losses are about $\$ 23$ billion for all New York counties. Clearly, the quality of the inundation extent
used in HAZUS analyses has a significant effect on final results. In that the improved resolution and accuracy are largely do to the da fro the tomo co the data floging this deployment and campaign seems more than justed by the this deployment and campaign seems more than justified by the substantial improvement in final loss estimates. The value of
these findings for informing future post-storm reconstruction pens and estimation in

\section{References Cited}

Blake, E.S., Kimberlain, T.B., Berg, R.J., Cangialosi, J.P., and Beven, J.L., II, 2013, National Hurricane Center tropical cyclone report-Hurricane Sandy, accessed February 13, 2013 , Busciolano, Ronald, and Schubert, C.E., 2012, Tracking the storm tide from Hurricane Irene as it moved up the tion of Americe Geographers, 2012 Ans.], in AssociaOnline Abstracts \& Programs, New York, N. Y February 24 28, 2012. Association ary 24-28, 2012: Association of American Geographer http://meridian cftp:/ $\mathrm{meridian.aag.org} / \mathrm{c}$.

Fanelli, Colleen, and Fanelli, Paul, 2011, Hurricane Irene: National Oceanic and Atmospheric Administration wat National Oceanic and Atmospheric Administration wa
level and meteorological data report, 66 p., accessed September 16, 2013, at http://tidesandcurrents.noaa.gov/ publications/Hurricane_Irene_Water_Level_and_Meteorological_Data_Report.pdf/.

Fanelli, Colleen, Fanelli, Paul, and Wolcott, David, 2013, Hurricane Sandy: National Oceanic and Atmospheric Administration water level and meteorological data report, $60 \mathrm{p}$., (2012 Whe Level and Meteorological Data_Report.pdf/.

Federal Emergency Management Agency, 1979, Flood insurance study, Village of Green Island, New York, Albany County: Federal Emergency Management Agency Floo
Insurance Study Community no. 360009, 20 p., 5 pls.

Federal Emergency Management Agency, 1981a, Flood insurance study, Town of Stony Point, New York, Rockland County: Federal Emergency Management Agency Floo
Insurance Study Community no. 360693, 18 p., 11 pls.
Federal Emergency Management Agency, 1981b, Flood insurance study, Village of Piermont, New York, Rockland County: Federal Emergency Management Agency Floo Insurance Study Community no. 360687, 16 p., 2 pls.

Federal Emergency Management Agency, 1983, Flood insurance study, City of Poughkeepsie, New York, Dutchess Insurance Study Community no. 360222, 15 p., 2 pls.

Federal Emergency Management Agency, 1984, Flood insurance study, Town of Schodack, New York, Rensselaer County. Federal Emergency Managenent Agency Flood Insurance Study Community no. 361169, 25 p., 27 pls.

Federal Emergency Management Agency, 1989, Flood insurance study, Town of Coeymans, New York, Albany County: Federal Emergency Management Agency Flood Insurance

Federal Emergency Management Agency, 2007a, Flood insurance study, City of New York, New York-Bronx County, Richmond County, New York County, Queens County, Kings County: Federal Emergency Management Agen
Flood Insurance Study no. 360497V000A, 108 p.

Federal Emergency Management Agency, 2007b, Flood insurance study, Westchester County, New York (all jurisdic-
tions): Federal Emergency Management Agency Flood Insurance Study no. 36119CV001A, 205 p.

Federal Emergency Management Agency, 2008, Flood insurance study, Greene County, New York (all jurisdictions):
Federal Emergency Management Agency Flood Insurance Federal Emergency Management
Study no. 36039CV001A, $107 \mathrm{p}$.

Federal Emergency Management Agency, 2009a, Flood insurance study, Nassau County, New York (all jurisdictions): Study no. 36059CV000A, 98 p.

Federal Emergency Management Agency, 2009b, Flood insuance study, Orange County, New York (all jurisdictions): Federal Energency Managernent Agency Flood Insurance Study no. 36071CV001A, $157 \mathrm{p}$

Federal Emergency Management Agency, 2009c, Flood insurance study, Suffolk County, New York (all jurisdictions): Federal Emergency Management Agency Flood Insurance 103CV000A, $139 \mathrm{p}$.

Federal Emergency Management Agency, 2011, Flood insurance study, Ulster County, New York (all jurisdictions): ent Agency Flood Insurance Study no. 36111CV001A, 45

Federal Emergency Management Agency, 2012, Flood insurance study, Dutchess County, New York (all jurisdictions) Study no. 36027CV001A, $159 \mathrm{p}$ 
Federal Emergency Management Agency, 2013a, Coastal flood hazard mapping studies: Federal Emergency Management Agency fact sheet, 2 p., accessed July 9, 2013, at http://www.fema.gov/media-library/assets/ documents $/ 32751$ ? id $=7565 /$.

Federal Emergency Management Agency, 2013b, Digital flood insurance rate map (DFIRM) databases: Federal Emergency Management Agency Map Service Center Web page, accessed April 5-May 7, 2013, at https://msc.fema.gov/.

Federal Emergency Management Agency, 2013c, FEMA Map Service Center-FIRMettes: Federal Emergency Management Agency Map Service Center Web page, accessed June 3-July 8, 2013, at https://msc.fema.gov/webapp/wcs/ stores/servlet/info?storeId=10001\&catalogId=10001\&lan $\mathrm{gId}=-1 \&$ content=firmetteHelp_A\&title=FIRMettes.

Federal Emergency Management Agency, 2013d, Hazus - The Federal Emergency Management Agency's (FEMA's) methodology for estimating potential losses from disasters: Federal Emergency Management Agency Web page, accessed October 17, 2013, at http://www.fema.gov/hazus/.

Federal Emergency Management Agency, 2013e, Preliminary work map data for New York City: Federal Emergency Management Agency cloud GIS infrastructure production site, accessed June 11, 2013, at http://184.72.33.183/Public/ PreliminaryWorkMaps/NY/NYC/.

Holmes, R.R., Jr., Dinicola, K., 2010, 100-year flood-It's all about chance: U.S. Geological Survey General Information Product 106, 1 p. (Also available at http://pubs.usgs.gov/ gip/106/.)

McCallum, B.E., Painter, J.A., and Frantz, E.R., 2012, Monitoring inland storm tide and flooding from Hurricane Irene along the Atlantic coast of the United States, August 2011: U.S. Geological Survey Open-File Report 2012-1022, 29 p. (Also available at http://pubs.usgs.gov/of/2012/1022/.)

McCallum, B.E., Wicklein, S.M., Reiser, R.G., Busciolano, Ronald, Morrison, Jonathan, Verdi, R.J., Painter, J.A., Frantz, E.R., and Gotvald, A.J., 2013, Monitoring storm tide and flooding from Hurricane Sandy along the Atlantic coast of the United States, October 2012: U.S. Geological Survey Open-File Report 2013-1043, 42 p., http://pubs.usgs.gov/ of/2013/1043/.
National Aeronautics and Space Administration, 2013, Hurricane Sandy (Atlantic Ocean): National Aeronautics and Space Administration hurricanes/tropical cyclones-2012 storms Web page, accessed December 31, 2014, at http:/www. nasa.gov/mission_pages/hurricanes/archives/2012/h2012_ Sandy.html/.

National Hurricane Center, 2013a, NHC data in GIS formats: National Oceanic and Atmospheric Administration, National Weather Service, National Hurricane Center database, accessed August 12-September 10, 2013, at http://www. nhc.noaa.gov/gis/.

National Hurricane Center, 2013b, Saffir-Simpson hurricane wind scale: National Oceanic and Atmospheric Administration, National Weather Service, National Hurricane Center Web page, accessed October 1, 2013, at http://www.nhc. noaa.gov/aboutsshs.shtml/.

National Hurricane Center, 2013c, Sea, lake, and overland surges from hurricanes (SLOSH): National Oceanic and Atmospheric Administration, National Weather Service, National Hurricane Center Web page, accessed October 1, 2013, at http://www.nhc.noaa.gov/surge/slosh.php/.

National Ocean Service, 2013, Tide data-Station selection: National Oceanic and Atmospheric Administration Tides and Currents Database, accessed September 18, 2013, at http://www.co-ops.nos.noaa.gov/stations. html?type $=$ Water + Levels.

Schubert, C.E., and Busciolano, Ronald, 1994, Peak stormtide elevations produced by the December 1992 storm along the coast of Long Island, New York, with historical peak storm-tide elevations [abs.], in Association of Long Island Geologists, First Conference on Geology of Long Island and Metropolitan New York, Programs with Abstracts, State University of New York at Stony Brook, N.Y., April 23, 1994: Stony Brook, N.Y., State University of New York at Stony Brook, Department of Earth and Space Sciences, p. 130-136.

Schubert, C.E., and Busciolano, Ronald, 2013, Historic coastal flooding produced by Hurricane Sandy in southeastern New York [abs.], in National Hydrologic Warning Council, 2013 Training Conference and Exposition, Ponte Vedra, Fla., June 3-6, 2013: National Hydrologic Warning Council Web page, accessed July 22, 2014, at http:/www.hydrologicwarning.org/content.aspx?page_id $=70 \& c l u b \_i d=617218 \&$ \&item $\mathrm{id}=22227 \&$ cat_id $=22275$. 
Table 7 
Table 7. Peak storm-tide elevations produced by Hurricane Sandy at 346 high-water-mark sites, and the corresponding Federal Emergency recurrence intervals) in New York.

[High-water-mark site locations are shown in figure 2. FEMA, Federal Emergency Management Agency; NAVD 88, North American Vertical Datum of 1988; no, number,

\begin{tabular}{|c|c|c|c|c|c|c|c|c|c|}
\hline & & Site & & & FEMA flood e & ations for selc & $\begin{array}{l}\text { annual exce } \\
\text { in feet above }\end{array}$ & $\begin{array}{l}\text { ce probabilitic } \\
088\end{array}$ & ( recurrence intervals), \\
\hline & & & & & & Stillwate & od elevation & & \\
\hline $\begin{array}{l}\text { Map } \\
\text { no. }\end{array}$ & Identifier & $\begin{array}{c}\text { Latitude, } \\
\text { in decimal } \\
\text { degreess }\end{array}$ & $\begin{array}{c}\text { Longitude, } \\
\text { in decimal } \\
\text { degreess }\end{array}$ & $\begin{array}{c}\text { 'Coastal } \\
\text { flood } \\
\text { hazard zonen }\end{array}$ & $\begin{array}{l}10 \text { percent } \\
\text { (10 year) }\end{array}$ & $\begin{array}{l}2 \text { percent } \\
\text { (50 year) }\end{array}$ & $\begin{array}{l}1 \text { percent } \\
\text { (100 year) }\end{array}$ & $\begin{array}{l}0.2 \text { percent } \\
\text { (500 year) }\end{array}$ & $\begin{array}{l}\text { (100-year) base flood } \\
\text { elevation }\end{array}$ \\
\hline & & & & & & & & & ${ }^{23}$ Albany County \\
\hline 2 & HWM-NY-ALB-006 & 42.47331 & -73.79050 & $\mathrm{AE}$ & 10.2 & 13.8 & 15.6 & 19.6 & 15.2 \\
\hline 3 & HWM-NY-ALB-007 & 42.47344 & -73.79050 & $\mathrm{AE}$ & 10.2 & 13.8 & 15.6 & 19.6 & 15.2 \\
\hline 4 & HWM-NY-ALB-009 & 42.74684 & -73.68936 & A12 & 21.3 & 25.9 & 27.6 & 31.3 & 27.3 \\
\hline 5 & HWM-NY-ALB-010 & 42.74740 & -73.68924 & A12 & 21.3 & 25.9 & 27.6 & 31.3 & 27.3. \\
\hline & & & & & & & & & ${ }_{4,5}^{45}$ Dutchess County \\
\hline 7 & HWM-NY-DUT-001 & 41.70667 & -73.94013 & $\mathrm{AE}$ & 5.9 & 7.1 & 8.0 & 9.7 & 8 \\
\hline 8 & HWM-NY-DUT-002 & 41.70699 & -73.94000 & $\mathrm{x}$ & -- & -- & -- & 9.7 & -- \\
\hline 9 & HWM-NY-DUT-003 & 41.70874 & -73.93926 & $\mathrm{AE}$ & 5.9 & 7.1 & 8.0 & 9.7 & 8 \\
\hline 10 & HWM-NY-DUT-004 & 41.70865 & -73.93920 & $\mathrm{AE}$ & 5.9 & 7.1 & 8.0 & 9.7 & 8 \\
\hline 11 & HWM-NY-DUT-005 & 41.70853 & -73.93947 & $\mathrm{AE}$ & 5.9 & 7.1 & 8.0 & 9.7 & 8 \\
\hline 12 & HWM-NY-DUT-006 & 41.65165 & -73.94353 & $\mathrm{AE}$ & 5.9 & 7.1 & 8.0 & 9.7 & 8 \\
\hline 13 & HWM-NY-DUT-007 & 41.65172 & -73.94363 & $\mathrm{AE}$ & 5.9 & 7.1 & 8.0 & 9.7 & 8 \\
\hline & & & & & & & & & ${ }_{5}^{56}$ Greene County \\
\hline 15 & HWM-NY-GRE-001 & 42.34817 & -73.79239 & $\mathrm{AE}$ & 8.5 & 11.5 & 12.9 & 16.1 & 14 \\
\hline 16 & HWM-NY-GRE-002 & 42.34814 & -73.79247 & $\mathrm{AE}$ & 8.5 & 11.5 & 12.9 & 16.1 & 14 \\
\hline 17 & HWM-NY-GRE-003 & 42.34786 & -73.79256 & $\mathrm{AE}$ & 8.5 & 11.5 & 12.9 & 16.1 & 14 \\
\hline 18 & HWM-NY-GRE-004 & 42.26305 & -73.80639 & $\mathrm{AE}$ & 7.4 & 9.8 & 10.9 & 13.6 & 11 \\
\hline 19 & HWM-NY-GRE-005 & 42.26287 & -73.80664 & $\mathrm{AE}$ & 7.4 & 9.8 & 10.9 & 13.6 & 11 \\
\hline 20 & HWM-NY-GRE-006 & 42.26246 & -73.80628 & $\mathrm{AE}$ & 7.4 & 9.8 & 10.9 & 13.6 & 11 \\
\hline 21 & HWM-NY-GRE-007 & 42.26333 & -73.80640 & $\mathrm{AE}$ & 7.4 & 9.8 & 10.9 & 13.6 & 11 \\
\hline 22 & HWM-NY-GRE-008 & 42.21036 & -73.85409 & $\mathrm{AE}$ & 6.3 & 8.0 & 8.6 & 10.9 & 10 \\
\hline 23 & HWM-NY-GRE-009 & 42.21034 & -73.85379 & $\mathrm{AE}$ & 6.3 & 8.0 & 8.6 & 10.9 & 10 \\
\hline 24 & HWM-NY-GRE-010 & 42.21027 & -73.85436 & $\mathrm{AE}$ & 6.3 & 8.0 & 8.6 & 10.9 & 10 \\
\hline 25 & HWM-NY-GRE-011 & 42.21043 & -73.85438 & $\mathrm{AE}$ & 6.3 & 8.0 & 8.6 & 10.9 & 10 \\
\hline 26 & HWM-NY-GRE-012 & 42.21046 & -73.85430 & $\mathrm{AE}$ & 6.3 & 8.0 & 8.6 & 10.9 & 10 \\
\hline & & & & & & & & & ${ }^{5,7}$ Nassau County \\
\hline 44 & HWM-NY-NAS-001 & 40.61083 & -73.71500 & $\mathrm{AE}$ & 6.7 & 8.4 & 9.3 & 10.4 & 9 \\
\hline 45 & ${ }^{19} \mathrm{HWM}-\mathrm{NY}-\mathrm{NAS}-220$ & 40.58705 & -73.73468 & $\mathrm{AE}$ & 6.7 & 8.8 & 11.1 & 12.0 & 15 \\
\hline 46 & ${ }^{19} \mathrm{HWM}-\mathrm{NY}-\mathrm{NAS}-221$ & 40.58619 & -73.71098 & $\mathrm{AE}$ & 6.7 & 8.9 & 14.0 & 12.4 & 14 \\
\hline 47 & ${ }^{19} \mathrm{HWM}-\mathrm{NY}-\mathrm{NAS}-222$ & 40.58958 & -73.61233 & $\mathrm{AE}$ & 6.5 & 8.1 & 9.5 & 10.0 & 13 \\
\hline 48 & HWM-NY-NAS-223 & 40.59228 & -73.57712 & $\mathrm{AE}$ & 6.4 & 7.5 & 7.9 & 8.6 & 9 \\
\hline 49 & HWM-NY-NAS-224 & 40.60113 & -73.50374 & $\mathrm{AE}$ & 5.7 & 6.7 & 7.1 & 7.7 & 8 \\
\hline 50 & HWM-NY-NAS-225 & 40.58967 & -73.55444 & $\mathrm{AE}$ & 6.4 & 7.5 & 7.9 & 8.6 & 8 \\
\hline 51 & HWM-NY-NAS-416 & 40.65380 & -73.45880 & $\mathrm{AE}$ & 5.2 & 6.2 & 6.5 & 7.2 & 7 \\
\hline 52 & ${ }^{19} \mathrm{HWM}-\mathrm{NY}-\mathrm{NAS}-501$ & 40.87750 & -73.53017 & $\mathrm{AE}$ & 6.3 & 8.7 & 9.9 & 12.0 & 11 \\
\hline 53 & ${ }^{19} \mathrm{HWM}-\mathrm{NY}-\mathrm{NAS}-502$ & 40.87593 & -73.53659 & $\mathrm{AE}$ & 6.3 & 8.7 & 9.9 & 12.0 & 11 \\
\hline 54 & HWM-NY-NAS-512 & 40.79520 & -73.75320 & $\mathrm{x}$ & -- & -- & -- & 12.8 & -- \\
\hline 55 & ${ }^{19} \mathrm{HWM}-\mathrm{NY}-\mathrm{NAS}-513$ & 40.81418 & -73.76414 & $\mathrm{VE}$ & 6.8 & 9.9 & 11.3 & 12.8 & 17 \\
\hline 56 & ${ }^{19} \mathrm{HWM}-\mathrm{NY}-\mathrm{NAS}-516$ & 40.81764 & -73.71872 & $\mathrm{AE}$ & 7.3 & 9.9 & 11.3 & 13.5 & 14 \\
\hline 57 & ${ }^{19} \mathrm{HWM}-\mathrm{NY}-\mathrm{NAS}-517$ & 40.82108 & -73.70426 & $\mathrm{AE}$ & 7.3 & 10.2 & 11.5 & 13.5 & 13 \\
\hline 58 & ${ }^{19} \mathrm{HWM}-\mathrm{NY}-\mathrm{NAS}-518$ & 40.83497 & -73.72870 & $\mathrm{AE}$ & 7.3 & 9.9 & 11.5 & 13.5 & 13 \\
\hline & & & & & & & & & \\
\hline
\end{tabular}

Management Agency flood elevations for the 10-, 2-, 1-, and 0.2-percent annual exceedance probabilities (10-, 50-, 100-, and 500-year

GMT, Grenwich Mean Time; < less than: >, greater than; \&, and; --, no value; USGS, U. S. Geological Survey]

\section{Hurricane Sandy peak storm tide}

High-water mark

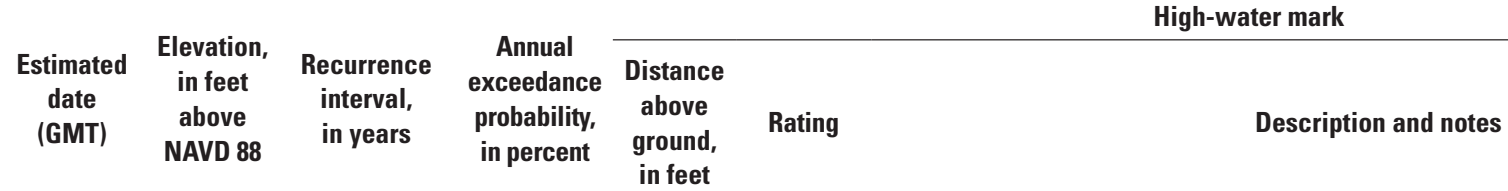

\begin{tabular}{|c|c|c|c|c|c|c|}
\hline 10/30/2012 & 10.2 & 10 & 10 & 0.0 & Fair & Fair debris line across field in park \\
\hline 10/30/2012 & 10.0 & $<10$ & $>10$ & 0.0 & Poor & Poor debris line along field in park \\
\hline 10/30/2012 & 10.6 & $<10$ & $>10$ & 0.0 & Poor & Poor debris line on right bank rip-rap \\
\hline 10/30/2012 & 10.7 & $<10$ & $>10$ & 0.0 & Poor & Poor debris line on right bank rip-rap \\
\hline 10/30/2012 & 9.0 & $>100 \&<500$ & $<1 \&>0.2$ & 4.0 & Good & Good seed line on back door of restaurant \\
\hline 10/30/2012 & 9.0 & $<500$ & $>0.2$ & 0.0 & Good & Good debris line on grass \\
\hline 10/30/2012 & 9.1 & $>100 \&<500$ & $<1 \&>0.2$ & 2.9 & Good & Good seed line on downstream exterior wall of Children's Museum \\
\hline 10/30/2012 & 9.0 & $>100 \&<500$ & $<1 \&>0.2$ & 2.4 & Good & Good seed line on streamward side of outbuilding \\
\hline 10/30/2012 & 9.0 & $>100 \&<500$ & $<1 \&>0.2$ & 2.7 & Good & Good seed line on upstream side of green power shed \\
\hline 10/30/2012 & 9.1 & $>100 \&<500$ & $<1 \&>0.2$ & 4.1 & Good & $\begin{array}{l}\text { Good seed line on outside of USGS streamgage— } 01372058 \text {-Hudson River below } \\
\text { Poughkeepsie, NY }\end{array}$ \\
\hline 10/30/2012 & 9.0 & $>100 \&<500$ & $<1 \&>0.2$ & 5.1 & Good & $\begin{array}{l}\text { Good mud line inside USGS streamgage—-01372058-Hudson River below } \\
\text { Poughkeepsie, NY }\end{array}$ \\
\hline 10/30/2012 & 9.6 & 20 & 5.0 & 1.9 & Good & Good seed line on white vinyl fence on Franklin Street \\
\hline 10/30/2012 & 9.7 & 30 & 3.3 & 4.0 & Good & Good seed and mud line on sliding glass door on Franklin Street \\
\hline 10/30/2012 & 9.2 & 20 & 5.0 & 0.0 & Good & Good debris line on lawn \\
\hline 10/30/2012 & 9.5 & 50 & 20 & $\ldots$ & Excellent & Excellent seed line on Athens wastewater treatment plant sion \\
\hline 10/30/2012 & 9.5 & 50 & 2.0 & -- & Excellent & Excellent seed line on outside of blue house \\
\hline $10 / 30 / 2012$ & 9.5 & 50 & 2.0 & -. & Excellent & Excellent seed line on white house \\
\hline 10/30/2012 & 9.5 & 50 & 2.0 & -- & Excellent & Excellent seed line on outside of red garage on wastewater treatment plant property \\
\hline 10/30/2012 & 8.5 & 90 & 1.1 & 3.1 & Good & Good seed line on cinder block wall behind dumpster \\
\hline 10/30/2012 & 9.6 & $>100 \&<500$ & $<1 \&>0.2$ & 3.9 & Good & Good seed/mud line on window of "Historic Catskill Point" building \\
\hline 10/30/2012 & 9.5 & $>100 \&<500$ & $<1 \&>0.2$ & 3.1 & Fair & Fair seed line on "Catskill Historical marker" sign on "Port of Call" restaurant \\
\hline $10 / 30 / 2012$ & 9.6 & $>100 \&<500$ & $<1 \&>0.2$ & 3.4 & Good & $\begin{array}{l}\text { Good seed line on gate for "Port of Call" restaurant }\end{array}$ \\
\hline 10/30/2012 & 9.6 & $>100 \&<500$ & $<1 \&>0.2$ & 3.5 & Good & Good mud line on "Port of Call" restaurant door \\
\hline 10/30/2012 & 9.8 & $>100 \&<500$ & $<1 \&>1$ & 0.0 & Fair & Fair debr \\
\hline $10 / 30 / 2012$ & 12.7 & $>500$ & $<0.2$ & 3.0 & Excellent & Excellent mud line inside the service entrance on inside wall at Ocean Boulevard \\
\hline 10/30/2012 & 10.6 & 70 & 1.4 & 0.6 & Good & $\begin{array}{l}\text { Good mud line inside maintenance shed to west of main entrance to Atlantic Beach Club } \\
\text { on Beach Street }\end{array}$ \\
\hline 10/30/2012 & 10.2 & $>500$ & $<0.2$ & 0.8 & Good & Good mud line inside small room and under air-conditioning unit \\
\hline 10/30/2012 & 9.3 & $>500$ & $<0.2$ & 0.6 & Fair & Fair seed line on field manager shed by mower shelter \\
\hline 10/30/2012 & 8.0 & $>500$ & $<0.2$ & 3.6 & Excellent & Excellent seed line on inside of pump station door \\
\hline 10/30/2012 & 8.7 & $>500$ & $<0.2$ & 1.5 & Excellent & Excellent seed and mud line on inside of concession stand building \\
\hline 10/29/2012 & 7.9 & $>500$ & $<0.2$ & 3.5 & Excellent & Excellent seed line on outside of shed \\
\hline 10/30/2012 & 9.8 & 100 & 1.0 & 1.0 & Good & Good seed line inside of building \\
\hline $10 / 30 / 2012$ & 10.1 & $>100 \&<500$ & $<1 \&>0.2$ & 0.8 & Good & Good seed line inside of building \\
\hline 10/30/2012 & 10.2 & $<500$ & $>0.2$ & 0.0 & Good & Good debris line in yard on Candy Lane \\
\hline 10/30/2012 & 10.8 & $<100$ & $>1$ & 0.0 & Fair & Fair debris line in yard on Steamboat Road \\
\hline 10/30/2012 & 9.7 & 50 & 2.0 & 0.0 & Fair & Fair debris line in yard on Pheasant Run Road \\
\hline 10/30/2012 & 10.0 & 50 & 2.0 & 2.5 & Good & Good seed line inside garage \\
\hline 10/30/2012 & 10.8 & 80 & 13 & 0.0 & Fair & Fair wash line in yard \\
\hline 10/30/2012 & 10.4 & 60 & 1.7 & 0.0 & Fair & 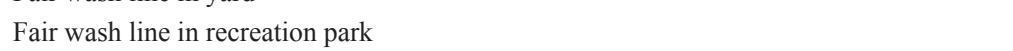 \\
\hline
\end{tabular}


Table 7. Peak storm-tide elevations produced by Hurricane Sandy at 346 high-water-mark sites, and the corresponding Federal Emergency ecurrence intervalss in New York.-Continued

[High-water-mark site locations are shown in figure 2. FEMA, Federal Emergency Management Agency; NAVD 88, North American Vertical Datum of 1988; no, number;

\begin{tabular}{cccccccccc}
\hline & & & \multicolumn{5}{c}{ FEMA flood elevations for selected annual exceedance probabilities (recurrence intervals), } \\
in feet above NAVD 88
\end{tabular}

\begin{tabular}{ccccccccc}
\hline 60 & HWM-NY-NAS-700 & 40.88750 & -73.56361 & AE & 6.3 & 8.7 & 9.4 & 12.0 \\
5. Nassau County-Continued
\end{tabular}

\section{$61 \quad{ }^{19} \mathrm{HWM}-\mathrm{NY}-\mathrm{NAS}-707 \quad 40.58398 \quad-73.64081$}

62 HWM-NY-NAS-708 $40.59076-73.64328$

63 HWM-NY-NAS-709 $40.59328-73.66889$

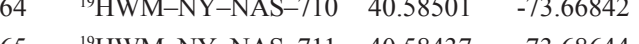

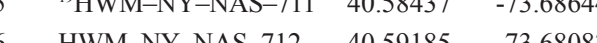

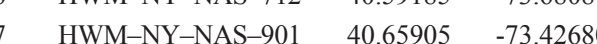

$\begin{array}{llll}\text { HWM-NY-NAS-902 } & 40.66249 & -73.44657\end{array}$

$\begin{array}{llll}\text { HWM-NY-NAS } 903 & 40.65387 & -73.46098\end{array}$

$\begin{array}{lll}\text { HWM-NY-NAS-904 } & 40.66478 & -73,47136\end{array}$

\begin{tabular}{lll} 
HWM-NY-NAS-906 & 40.65828 & -73.50484 \\
\hline
\end{tabular}

\begin{tabular}{llll} 
HWM-NY-NAS-907 & 40.64879 & -73.51624 \\
\hline
\end{tabular}

$\begin{array}{llll} & \text { HWM-NY-NAS-908 } & 40.66016 & -73.5291\end{array}$

$\begin{array}{llll}\text { HWM-NY-NAS-909 } & 40.65054 & -73.72746\end{array}$

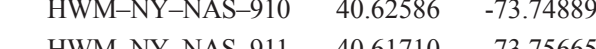

$\begin{array}{llll} & \text { HWM NYNAS } 912 & 40.61710 & -73.74869\end{array}$

$\begin{array}{lll}\text { HWM NYY NAS } 913 & 40.6548 & -73.73697\end{array}$

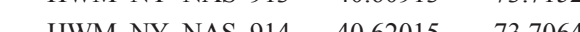

\begin{tabular}{llll} 
HWM-NYNAS 915 & 40.63459 & -73.6696 \\
\hline
\end{tabular}

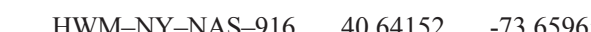

$\begin{array}{lll}\text { HWM-NY-NAS-917 } & 40.62223 & -73.64732\end{array}$

$\begin{array}{llll}\text { HWM-NY-NAS-918 } & 40.63071 & -73.6313 \\ \text { HWM-NY-NAS-919 } & 40.63021 & -7361309\end{array}$

\begin{tabular}{lll} 
HWM-NY-NAS-920 & 40.64001 & -7355957 \\
\hline
\end{tabular}

\begin{tabular}{lll} 
HWM-NY-NAS-921 & 40.63229 & -73.5828 \\
\hline
\end{tabular}

7 HWM-NY-NAS-922 $40.64760 \quad-73.5538$

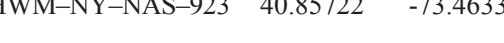

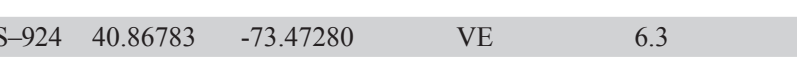

\begin{tabular}{llll} 
& "HWM-NY-NAS-925 & 40.87199 & -73.5036 \\
\hline
\end{tabular}

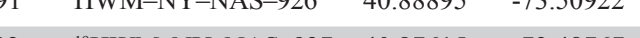

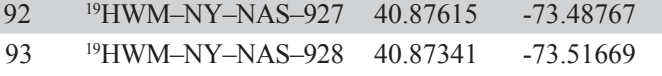

$\begin{array}{llll} & 19 \\ 9\end{array}$

\begin{tabular}{llll} 
& HWM-NY-NAS-930 & 40.90515 & -73.5433 \\
\hline
\end{tabular}

\begin{tabular}{llll} 
& \\
\hline
\end{tabular}

$\begin{array}{llll}\text { HWM-NY-NAS-933 } & 40.88625 & -73.5324\end{array}$

\begin{tabular}{llll} 
HWM-NY-NAS-934 & 40.91038 & -73.53987 \\
\hline
\end{tabular}

\begin{tabular}{llll} 
HWM-NY-NAS-935 & 40.91084 & -73.558 \\
\hline
\end{tabular}

$\begin{array}{llll}{ }^{*} \mathrm{HWM}-\mathrm{NY} Y \mathrm{NAS}-936 & 40.90816 & -73.58157\end{array}$

\begin{tabular}{llll} 
& & & \\
\hline
\end{tabular}

$103 \quad{ }^{19} \mathrm{HWM}-\mathrm{NY}-\mathrm{NAS}-939 \quad 40.89939 \quad-73.6276$

\begin{tabular}{|c|c|}
\hline $\mathrm{AE}$ & 6.7 \\
\hline $\mathrm{AE}$ & 6.6 \\
\hline $\mathrm{AE}$ & 6.7 \\
\hline $\mathrm{AE}$ & 6.7 \\
\hline $\mathrm{AE}$ & 6.7 \\
\hline $\mathrm{AE}$ & 6.7 \\
\hline $\mathrm{AE}$ & 5.2 \\
\hline $\mathrm{AE}$ & 5.2 \\
\hline $\mathrm{AE}$ & 5.2 \\
\hline $\mathrm{x}$ & -- \\
\hline $\mathrm{x}$ & -- \\
\hline $\mathrm{x}$ & -- \\
\hline $\mathrm{AE}$ & 6.0 \\
\hline $\mathrm{AE}$ & 4.9 \\
\hline $\mathrm{AE}$ & 4.9 \\
\hline $\mathrm{AE}$ & 4.9 \\
\hline $\mathrm{AE}$ & 6.7 \\
\hline $\mathrm{x}$ & -- \\
\hline $\mathrm{AE}$ & 6.7 \\
\hline $\mathrm{AE}$ & 6.7 \\
\hline $\mathrm{AE}$ & 6.7 \\
\hline $\mathrm{x}$ & -- \\
\hline $\mathrm{x}$ & -- \\
\hline $\mathrm{x}$ & -- \\
\hline $\mathrm{AE}$ & 6.4 \\
\hline $\mathrm{AE}$ & 6.4 \\
\hline $\mathrm{AE}$ & 6.0 \\
\hline $\mathrm{AE}$ & 6.3 \\
\hline
\end{tabular}

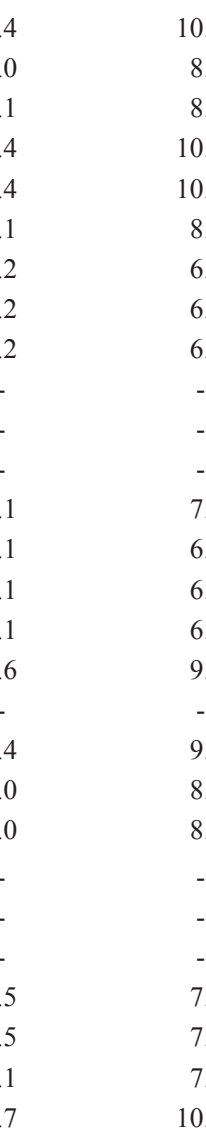

10.9

9.2

7.2

$--$

8.4
8.4

$8.7 \quad 104$

$10.4-12.0-2=24=0$

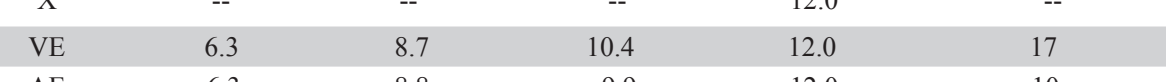$$
6.3
$$

6.3

6.3

$\mathrm{AE}$

$\mathrm{AO}$

$\mathrm{AE}$
$\mathrm{AE}$

8.8
8.7
-
8.7
--
8.7
8.7
--
8.7
8.9
8.8

10

--
10

9.8

9.4

12.0
12.0
12.0

$9.4-12.0$
$-\quad 12.0$

$\begin{array}{rr}-- & 12.0 \\ 9.4 & 12.0 \\ 11.4 & 13.0\end{array}$

$\begin{array}{rrrr}6.7 & 8.9 & 11.4 & 13.0 \\ 6.4 & 8.8 & 12.7 & 13.0\end{array}$ $\begin{array}{ll}13.0 & 11 \\ 13.0 & 15\end{array}$
Management Agency flood elevations for the 10-, 2-, 1-, and 0.2-percent annual exceedance probabilities (10-, 50-, 100-, and 500-year

GMT, Grenwich Mean Time; $<$, less than; > , greater than; \&, and; --, no value; USGS, U.S. Geological Survey]

Hurricane Sandy peak storm tide

High-water mark

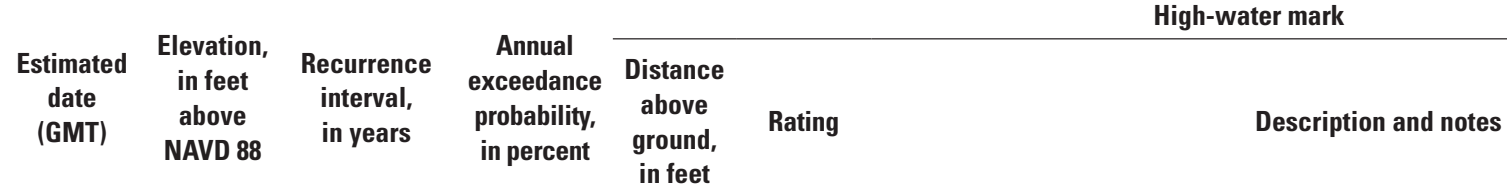

\begin{tabular}{|c|c|c|c|c|c|c|}
\hline 10/30/2012 & 10.2 & $>100 \&<500$ & $<1 \&>0.2$ & 2.2 & Excellent & $\begin{array}{l}\text { Excellent seed line inside USGS streamgage— } 01303000 \text {-Mill Neck Creek at Mill } \\
\text { Neck, NY }\end{array}$ \\
\hline 10/30/2012 & 10.7 & $>100 \&<500$ & $<1 \&>0.2$ & 1.1 & Good & Good mud line on beach wall \\
\hline 10/30/2012 & 9.3 & $>500$ & $<0.2$ & 1.3 & Excellent & Excellent mud line on inside wall of house \\
\hline 10/30/2012 & 8.7 & $>100 \&<500$ & $<1 \&>0.2$ & 0.8 & Excellent & Excellent mud line on inside wall of house \\
\hline 10/30/2012 & 11.6 & $>500$ & $<0.2$ & 1.7 & Excellent & Excellent mud line on back of building \\
\hline 10/30/2012 & 9.7 & 90 & 1.1 & 0.4 & Good & Good mud line on front of building \\
\hline 10/30/2012 & 9.5 & $>500$ & $<0.2$ & -- & Good & Good mud line on side of fence \\
\hline 10/29/2012 & 7.5 & $>500$ & $<0.2$ & 3.5 & Excellent & Excellent seed line on side of house \\
\hline 10/29/2012 & 7.7 & $>500$ & $<0.2$ & 1.3 & Excellent & Excellent seed line on inside wall of building \\
\hline 10/30/2012 & 8.0 & $>500$ & $<0.2$ & 3.3 & Good & Good seed line on side of house \\
\hline 10/30/2012 & 8.4 & $>500$ & $<0.2$ & 0.8 & Good & Good seed line on side of fence \\
\hline 10/30/2012 & 7.9 & $>500$ & $<0.2$ & 0.0 & Good & Good debris line on grassy hill \\
\hline 10/29/2012 & 8.5 & $>500$ & $<0.2$ & 0.9 & Good & Good seed line on side of fence \\
\hline 10/29/2012 & 8.6 & $>500$ & $<0.2$ & 2.5 & Excellent & Excellent seed line on side of fence \\
\hline 10/30/2012 & 8.8 & $>500$ & $<0.2$ & 1.0 & Excellent & Excellent seed line on side of house \\
\hline 10/30/2012 & 10.4 & $>500$ & $<0.2$ & 1.3 & Excellent & Excellent seed line on front of house \\
\hline 10/30/2012 & 10.2 & $>500$ & $<0.2$ & 4.3 & Excellent & Excellent seed line on front of house \\
\hline 10/29/2012 & 9.8 & $>100 \&<500$ & $<1 \&>0.2$ & 2.8 & Excellent & Excellent seed line on side of house \\
\hline 10/29/2012 & 10.0 & $<500$ & $>0.2$ & 0.0 & Poor & Poor debris line on grass lawn \\
\hline $10 / 29 / 2012$ & 10.1 & $>100 \&<500$ & $<1 \&>0.2$ & 1.9 & Excellent & Excellent seed line on front of house \\
\hline 10/29/2012 & 9.6 & $>500$ & $<0.2$ & 1.2 & Excellent & Excellent seed line on side of house \\
\hline 10/29/2012 & 8.5 & $>100 \&<500$ & $<1 \&>0.2$ & 1.8 & Good & Good seed line on front of building \\
\hline 10/29/2012 & 9.4 & $>500$ & $<0.2$ & 1.1 & Excellent & Excellent seed line on side of building \\
\hline 10/29/2012 & 9.4 & $>500$ & $<0.2$ & 1.6 & Excellent & Excellent seed line on front of house \\
\hline 10/29/2012 & 9.3 & $>500$ & $<0.2$ & 2.5 & Excellent & Excellent seed line on side of fence \\
\hline 10/29/2012 & 9.2 & $>500$ & $<0.2$ & 3.3 & Excellent & Excellent seed line on front of house \\
\hline 10/29/2012 & 9.0 & $>500$ & $<0.2$ & 4.6 & Good & Good seed line on front of house \\
\hline 10/29/2012 & 8.4 & $>500$ & $<0.2$ & 2.8 & Excellent & Excellent seed line on side of fence \\
\hline 10/30/2012 & 9.7 & 80 & 1.3 & 3.7 & Excellent & $\begin{array}{l}\text { Excellent cork line inside USGS streamgage — } 01303500 \text { Cold Spring Brook at Cold } \\
\text { Spring Harbor, NY }\end{array}$ \\
\hline 10/30/2012 & 10.0 & $<100$ & $>1$ & 0.0 & Fair & Fair debris line on grass \\
\hline 10/30/2012 & 10.2 & $>100 \&<500$ & $<1 \&>0.2$ & 1.9 & Excellent & Excellent seed line on back of house \\
\hline 10/30/2012 & 9.8 & $<500$ & $>0.2$ & 0.0 & Good & Good debris line on lawn \\
\hline 10/29/2012 & 9.5 & $<100$ & $>1$ & 2.0 & Excellent & Excellent seed line on shed \\
\hline 10/30/2012 & 10.0 & $>100 \&<500$ & $<1 \&>0.2$ & 1.2 & Excellent & Excellent seed line on side of fence \\
\hline 10/30/2012 & 9.6 & 90 & 1.1 & 3.1 & Excellent & Excellent seed line on tree \\
\hline 10/30/2012 & 10.0 & $<500$ & $>0.2$ & 0.0 & Good & Good debris line \\
\hline 10/30/2012 & 9.8 & 100 & 1.0 & 0.0 & Good & Good debris line on lawn \\
\hline 10/30/2012 & 9.7 & $<500$ & $>0.2$ & 1.1 & Excellent & Excellent seed line on back of building \\
\hline 10/30/2012 & 10.0 & $>100 \&<500$ & $<1 \&>0.2$ & 2.3 & Excellent & Excellent seed line on side of garage \\
\hline 10/30/2012 & 8.1 & 40 & 2.5 & 0.7 & Good & Good seed line on side of fence \\
\hline 10/30/2012 & 11.1 & $<500$ & $>0.2$ & 1.7 & Excellent & Excellent seed line on side of fence \\
\hline 10/30/2012 & 10.4 & $>100 \&<500$ & $<1 \&>0.2$ & 1.3 & Excellent & Excellent seed line on fence \\
\hline 10/30/2012 & 10.0 & 70 & 1.4 & 1.8 & Excellent & Excellent seed line on door \\
\hline 10/30/2012 & 9.9 & 60 & 1.7 & 0.8 & Good & Good seed line on tree \\
\hline
\end{tabular}


Table 7. Peak storm-tide elevations produced by Hurricane Sandy at 346 high-water-mark sites, and the corresponding Federal Emergency recurrence intervals in New York.-Continued

[High-water-mark site locations are shown in figure 2. FEMA, Federal Emergency Management Agency; NAVD 88, North American Vertical Datum of 1988; no., number;

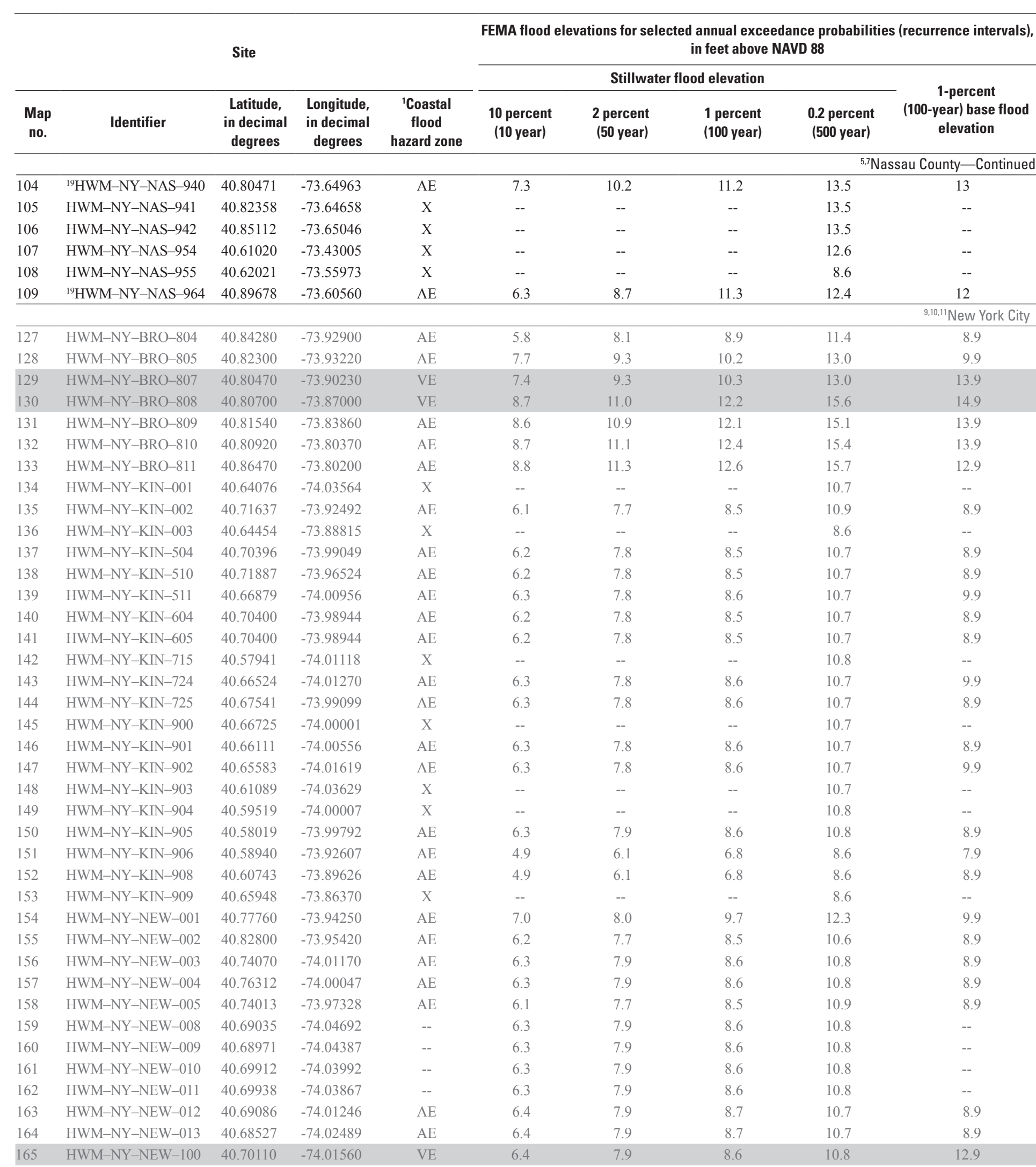

Management Agency flood elevations for the 10-, 2-, 1-, and 0.2-percent annual exceedance probabilities (10-, 50-, 100-, and 500-year

GMT, Grenwich Mean Time; $<$ less than; $>$ greater than; \&, and; --, no value; USGS, U.S. Geological Survey]

\section{Hurricane Sandy peak storm tide}

\begin{tabular}{|c|c|c|c|c|c|c|}
\hline \multirow[b]{3}{*}{$\begin{array}{l}\text { Estimated } \\
\text { date } \\
\text { (GMT) }\end{array}$} & \multirow[b]{3}{*}{$\begin{array}{c}\text { Elevation, } \\
\text { in feet } \\
\text { above } \\
\text { NAVD } 88\end{array}$} & \multirow[b]{3}{*}{$\begin{array}{l}\text { Recurrence } \\
\text { interval, } \\
\text { in years }\end{array}$} & \multicolumn{4}{|c|}{ Hurricane Sandy peak storm tide } \\
\hline & & & & & & ter mark \\
\hline & & & $\begin{array}{l}\text { Annual } \\
\text { exceedance } \\
\text { probability, } \\
\text { in percent }\end{array}$ & $\begin{array}{c}\text { Distance } \\
\text { above } \\
\text { ground, } \\
\text { in feet }\end{array}$ & Rating & Description and notes \\
\hline
\end{tabular}

\begin{tabular}{|c|c|c|c|c|c|c|}
\hline 10/30/2012 & 10.2 & 50 & 2.0 & 0.9 & Excellent & Excellent seed line on side of building \\
\hline 10/30/2012 & 10.2 & $<500$ & $>0.2$ & 0.8 & Excellent & Excellent seed line \\
\hline $10 / 30 / 2012$ & 10.9 & $<500$ & $>0.2$ & 0.0 & Poor & Poor debris line on beach \\
\hline 10/29/2012 & 7.1 & $<500$ & $>0.2$ & 1.3 & Excellent & Excellent seed line on building \\
\hline 10/29/2012 & 8.7 & $>500$ & $<0.2$ & 0.0 & Good & Good debris line \\
\hline 10/30/2012 & 7.7 & 30 & 3.3 & 2.2 & Good & Good seed line on inside corner of back of house \\
\hline $10 / 30 / 2012$ & 9.7 & $>100 \&<500$ & $<1 \&>0.2$ & 2.1 & Excellent & Excellent seed line on side of fence \\
\hline 10/30/2012 & 9.9 & 80 & 1.3 & 0.0 & Good & Good mud line on concrete path \\
\hline 10/30/2012 & 10.6 & $<100$ & $>1$ & 1.0 & Good & Good seed line inside guard booth \\
\hline 10/30/2012 & 10.3 & $<100$ & $>1$ & 0.0 & Good & Good debris line in grass field \\
\hline 10/30/2012 & 10.7 & 50 & 2.0 & 3.4 & Fair & Fair debris line on fence \\
\hline $10 / 30 / 2012$ & 10.4 & 40 & 2.5 & 0.0 & Good & Good debris line on grass \\
\hline $10 / 30 / 2012$ & 10.2 & 30 & 3.3 & 0.0 & Good & Good debris line on grass \\
\hline 10/30/2012 & 11.3 & $>500$ & $<0.2$ & 0.4 & Good & Good seed line on inside door to shed \\
\hline 10/30/2012 & 10.9 & 500 & 0.2 & 2.2 & Good & Good mud line on door of building \\
\hline 10/30/2012 & 11.0 & $>500$ & $<0.2$ & 4.1 & Good & Good seed line on garage door of house \\
\hline 10/30/2012 & 11.3 & $>500$ & $<0.2$ & 4.4 & Good & Good seed line in window of Bubby's Restaurant and Bar \\
\hline 10/30/2012 & 11.2 & $>500$ & $<0.2$ & 2.6 & Good & Good seed line inside of office building \\
\hline $10 / 30 / 2012$ & 11.2 & $>500$ & $<0.2$ & 4.1 & Good & Good mud line on metal door inside concrete building \\
\hline 10/30/2012 & 11.0 & $>500$ & $<0.2$ & 1.6 & Good & Good seed line on front of building \\
\hline $10 / 30 / 2012$ & 10.9 & $>500$ & $<0.2$ & -- & Good & Good seed line on back of guard booth \\
\hline 10/29/2012 & 12.4 & $>500$ & $<0.2$ & & Excellent & Excellent mud line on outside of house \\
\hline 10/29/2012 & 11.3 & $>500$ & $<0.2$ & 3.6 & Good & Good seed line on side of building \\
\hline 10/29/2012 & 9.8 & $>100 \&<500$ & $<1 \&>0.2$ & 3.2 & Excellent & Excellent mud line on side of building \\
\hline $10 / 30 / 2012$ & 11.0 & $>500$ & $<0.2$ & -- & Fair & Fair debris line on chain link fence \\
\hline $10 / 30 / 2012$ & 11.2 & $>500$ & $<0.2$ & 3.0 & Fair & Fair wash line in compost \\
\hline $10 / 30 / 2012$ & 11.5 & $>500$ & $<0.2$ & 4.5 & Fair & Fair seed line on trailer \\
\hline $10 / 30 / 2012$ & 12.9 & $>500$ & $<0.2$ & 0.0 & Poor & Poor debris line \\
\hline $10 / 30 / 2012$ & 11.5 & $>500$ & $<0.2$ & 1.1 & Excellent & Excellent seed line on wall inside building \\
\hline $10 / 30 / 2012$ & 11.5 & $>500$ & $<0.2$ & 0.0 & Good & Good debris line around hill side \\
\hline 10/30/2012 & 10.9 & $>500$ & $<0.2$ & 4.0 & Excellent & Excellent seed line on side of house \\
\hline $10 / 30 / 2012$ & 11.2 & $>500$ & $<0.2$ & 3.6 & Good & Good seed line on trailer \\
\hline $10 / 30 / 2012$ & 10.0 & $>500$ & $<0.2$ & 1.1 & Excellent & Excellent mud line on inside of security hut \\
\hline $10 / 30 / 2012$ & 10.4 & $>100 \&<500$ & $<1 \&>0.2$ & 2.4 & Poor & Poor debris line in ornamental grass \\
\hline $10 / 30 / 2012$ & 9.5 & $>100 \&<500$ & $<1 \&>0.2$ & 0.0 & Fair & Fair debris line on lawn \\
\hline $10 / 30 / 2012$ & 12.3 & $>500$ & $<0.2$ & & Fair & Fair mud line on interior wall of fire house \\
\hline 10/30/2012 & 10.4 & $>100 \&<500$ & $<1 \&>0.2$ & 2.6 & Excellent & Excellent seed line on building \\
\hline $10 / 30 / 2012$ & 10.8 & 500 & 0.2 & 2.5 & Good & Good debris line on fence \\
\hline $10 / 30 / 2012$ & 11.3 & $>500$ & $<0.2$ & 4.1 & Excellent & Excellent seed line inside of maintenance room \\
\hline 10/30/2012 & 11.4 & $>500$ & $<0.2$ & 0.0 & Fair & Fair debris line near base of Statue of Liberty \\
\hline $10 / 30 / 2012$ & 11.1 & $>500$ & $<0.2$ & -- & Good & Good seed line inside door of Immigration Museum \\
\hline $10 / 30 / 2012$ & 11.1 & $>500$ & $<0.2$ & 0.0 & Poor & Poor debris line on grass hill \\
\hline $10 / 30 / 2012$ & 11.0 & $>500$ & $<0.2$ & 2.5 & Excellent & Excellent seed line on glass door inside brick building \\
\hline $10 / 30 / 2012$ & 11.2 & $>500$ & $<0.2$ & 2.0 & Excellent & Excellent seed line inside shed \\
\hline 0/30/2012 & 11.6 & $<100$ & $>1$ & & Good & ow of building \\
\hline
\end{tabular}


Table 7. Peak storm-tide elevations produced by Hurricane Sandy at 346 high-water-mark sites, and the corresponding Federal Emergency recurrence intervals) in New York.-Continued

[High-water-mark site locations are shown in figure 2. FEMA, Federal Emergency Management Agency; NAVD 88, North American Vertical Datum of 1988; no., number;

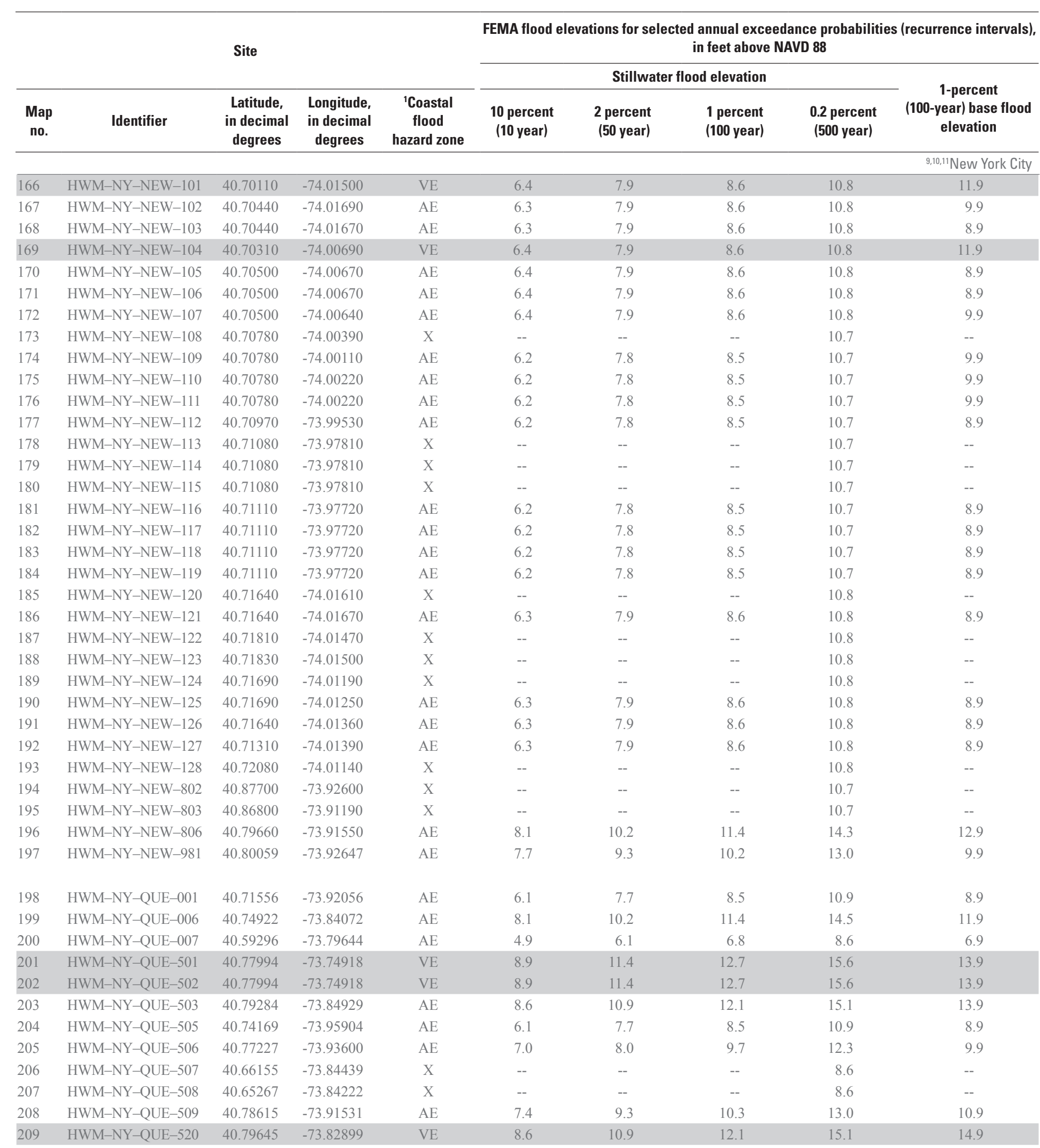

Management Agency flood elevations for the 10-, 2-, 1-, and 0.2-percent annual exceedance probabilities (10-, 50-, 100-, and 500-year

GMT, Grenwich Mean Time; $<$ less than; $>$ greater than; \&, and; --, no value; USGS, U.S. Geological Survey]

\section{Hurricane Sandy peak storm tide}

\begin{tabular}{|c|c|c|c|c|c|c|}
\hline \multicolumn{7}{|c|}{$\begin{array}{l}\text { Hurricane Sandy peak storm tide } \\
\end{array}$} \\
\hline & & & & & & ter mark \\
\hline $\begin{array}{l}\text { Estimated } \\
\text { date } \\
\text { (GMT) }\end{array}$ & $\begin{array}{c}\text { Elevation, } \\
\text { in feet } \\
\text { above } \\
\text { NAVD } 88\end{array}$ & $\begin{array}{c}\text { Receurrence } \\
\text { interval, } \\
\text { in years }\end{array}$ & $\begin{array}{c}\text { Annual } \\
\text { exceedance } \\
\text { probability, } \\
\text { in percent }\end{array}$ & $\begin{array}{c}\text { Distance } \\
\text { above } \\
\text { ground, } \\
\text { in feet }\end{array}$ & Rating & Description and notes \\
\hline
\end{tabular}

$\begin{array}{lllllll}1030 / 2012 & 11.4 & <100 & >1 & - & \text { Good } & \text { Good mud line on patio of building }\end{array}$

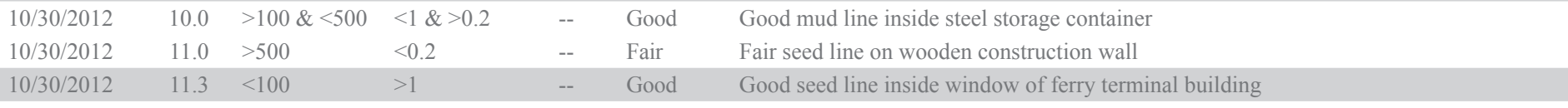

$10 / 30 / 2012 \quad 11.3<100$

$10 / 30 / 2012$

$\begin{array}{lll}10 / 30 / 2012 & 11.2 & >500 \\ 10 / 30 / 2012 & 11.2 & >500\end{array}$

$10 / 30 / 2012 \quad 11.1>500$

$10 / 30 / 2012 \quad 11.0 \quad>50$

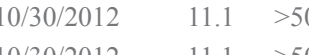

$10 / 302012 \quad 112>500$

$10 / 30 / 2012 \quad 11.2>500$

$10 / 30 / 2012 \quad 10.9 \quad>50$

$10 / 30 / 2012 \quad 10.9>50$

$10 / 30 / 2012 \quad 10.9>500$

$10 / 30 / 2012 \quad 10.9>500$

$10 / 30 / 2012 \quad 11.0 \quad>500$

$10 / 30 / 2012 \quad 10.9>500$

$10 / 30 / 2012 \quad 10.9>500$

$10 / 30 / 2012 \quad 10.9>500$

$10 / 30 / 2012 \quad 11.3 \quad>500$

$\begin{array}{lll}10 / 30 / 2012 & 11.1 & >500 \\ 10 / 302012 & 109 & >500\end{array}$

$10302012 \quad 106 \quad 500$

$\begin{array}{lllll}9.8 & >100 \&<500 & <1 \&>0.2 & 4.3 & \text { Good } \quad \text { Good seed line on outside wall of building }\end{array}$

$\begin{array}{lllll}9.7 & >100 \&<500 & <1 \&>0.2 & 4.7 & \text { Good } \quad \text { Good mud line on window of building }\end{array}$

$\begin{array}{lll}0.730 / 2012 & 10.8 & 500 \\ 10302012 & 9.5 & <50\end{array}$

$\begin{array}{rrlllll}10 / 30 / 2012 & 9.0 & <500 & >0.2 & 2.1 & \text { Excellent } & \text { Excellent seed line on guard booth } \\ 10 / 30 / 2012 & 11.1 & 90 & 1.1 & 3.1 & \text { Fair } & \text { Fair debris line on side of fence }\end{array}$

$\begin{array}{llllll}1.1 & 3.1 & \text { Fair } & \text { Fair debris line on side of fence }\end{array}$

$\begin{array}{lllllll}10 / 30 / 2012 & 10.9 & 500 & 0.2 & 6.0 & \text { Excellent } & \text { Excellent mud line on door of storage container }\end{array}$

$\begin{array}{rrrrrll}10 / 30 / 2012 & 7.8 & <10 & >10 & 0.0 & \text { Fair } & \text { Fair debris line on lawn } \\ 10 / 302012 & 10.7 & >500 & <02 & 4.5 & \text { Good } & \text { Gooddebris line on fowe }\end{array}$

$\begin{array}{lllllll}10 / 30 / 2012 & 10.7 & >500 & <0.2 & 4.5 & \text { Good } & \text { Good debris line on fence } \\ 10.302012 & 10.3 & <100 & >1 & 3.5 & \text { Good } & \text { Good seed line on power pote in }\end{array}$

$\begin{array}{lllllll}10 / 30 / 2012 & 103 & <100 & >1 & 2.1 & \text { Good } & \text { Good seed line on house garage }\end{array}$

$\begin{array}{lllllll}10 / 30 / 2012 & 10.3 & <100 & >1 & 2.1 & \text { Good } & \text { Good seed line on house garage } \\ 10.12012 & 10.1 & 40 & 2.5 & 0.0 & \text { Good } & \text { Good wash line in park }\end{array}$

$\begin{array}{lllllll}10 / 30 / 2012 & 10.7 & 500 & 2.5 & 0.0 & \text { Good } & \text { Good wash line in park frak faility }\end{array}$

$\begin{array}{llllll}10 / 30 / 2012 & 10.9 & >100 \&<500 & <1 \&>0.2 & 4.0 & \text { Good } \quad \text { Good seed line on windows and brick of apartment building }\end{array}$

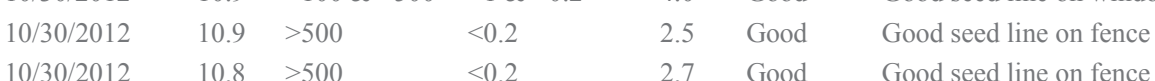

$10 / 30 / 2012 \quad 10.5 \quad>100 \&<500 \quad<1 \&>0.2 \quad 0.0 \quad$ Poor $\quad$ Poor wash line on green space in part 
Table 7. Peak storm-tide elevations produced by Hurricane Sandy at 346 high-water-mark sites, and the corresponding Federal Emergency recurrence intervals) in New York.-Continued

[High-water-mark site locations are shown in figure 2. FEMA, Federal Emergency Management Agency; NAVD 88, North American Vertical Datum of 1988; no, number;

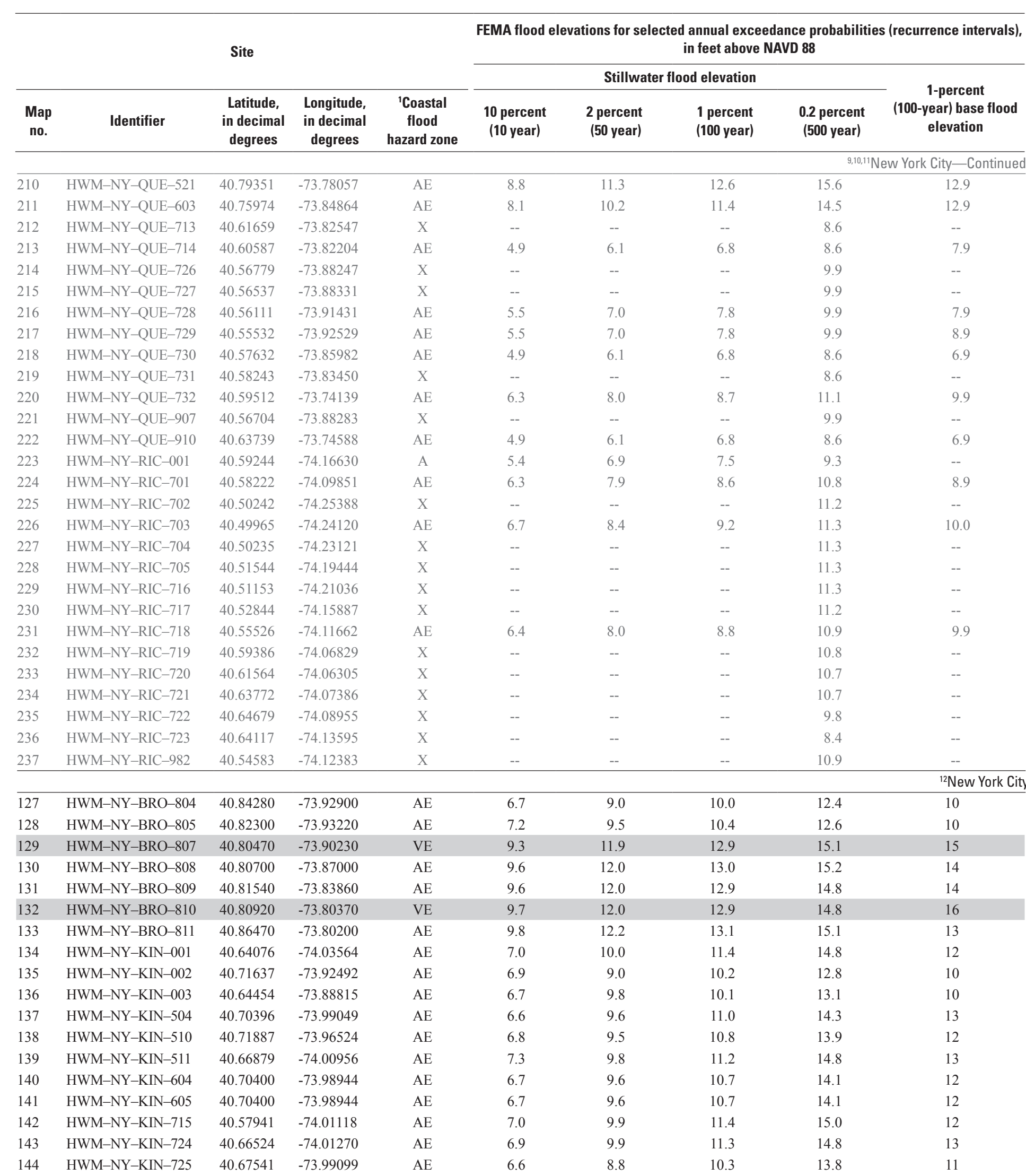

Management Agency flood elevations for the 10-, 2-, 1-, and 0.2-percent annual exceedance probabilities (10-, 50-, 100-, and 500-year

GMT, Grenwich Mean Time; $<$ less than; $>$ greater than; \&, and; --, no value; USGS, U.S. Geological Survey]

\section{Hurricane Sandy peak storm tide}

High-water mark

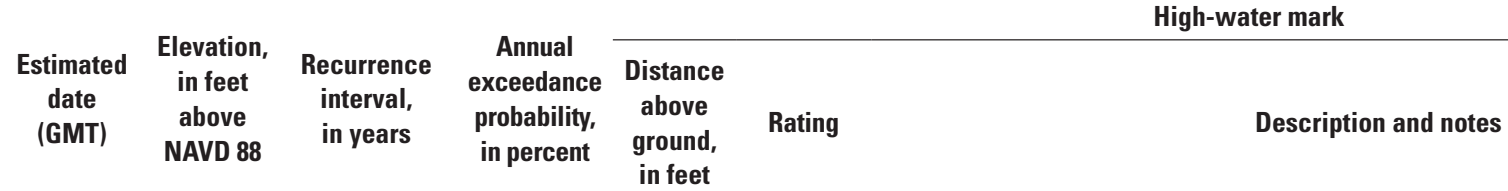

$\begin{array}{lllllll}10 / 30 / 2012 & 10.6 & 40 & 2.5 & 0.0 & \text { Poor } & \text { Poor debris line on grass }\end{array}$

$\begin{array}{lllllll}10 / 30 / 2012 & 10.5 & 60 & 1.7 & 0.0 & \text { Poor } & \text { Poor debris line in parking lot }\end{array}$

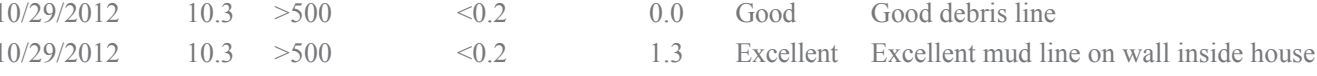

$\begin{array}{llllll}\text { 10/30/2012 } & 10.5 & >500 & <0.2 & 0.0 & \text { Excellent Excellent debris line }\end{array}$

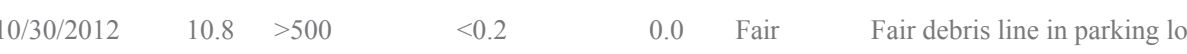

$\begin{array}{lllllll}10 / 29 / 2012 & 10.7 & >500 & < & 3.2 & 3.6 & \text { Excellent Excellent mud line on wall inside building }\end{array}$

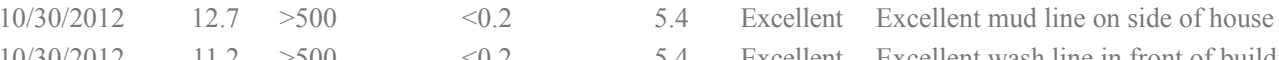

$\begin{array}{lllllll}10 / 30 / 2012 & 11.2 & >500 & <0.2 & 5.4 & \text { Excellent } & \text { Excellent wash line in front of build } \\ 10 / 30 / 2012 & 10.3 & >500 & <0.2 & - & \text { Fair } & \text { Fair mud line on wall }\end{array}$

10/30/2012 $\quad 9.0>100 \&<500 \quad<1 \&>0.2 \quad--\quad$ Good $\quad$ Good seed line on side of building

\begin{tabular}{llllll}
$10 / 30 / 2012$ & 11.0 & $>500$ & $<0.2$ & 4.2 & Excellent \\
\hline
\end{tabular}

$\begin{array}{llllll}10 / 30 / 2012 & 10.6 & >500 & <0.2 & 4.6 & \text { Good } \quad \text { Good seed line on inside side of concrete wall }\end{array}$

$\begin{array}{llllll}10 / 30 / 2012 & 12.3 & >500 & <0.2 & 4.3 & \text { Excellent } \\ & \text { Excellent seed line on wall of garage }\end{array}$

$\begin{array}{llllll}10 / 30 / 2012 & 12.5 & >500 & <0.2 & 4.7 & \text { Fair }\end{array}$

$\begin{array}{lllllll}10 / 30 / 2012 & 13.1 & >500 & <0.2 & 0.0 & \text { Good } & \text { Good debris line on grass }\end{array}$

$\begin{array}{llllll}10 / 29 / 2012 & 13.2 & >500 & <0.2 & 5.5 & \text { Fair } \quad \text { Fair seed line on side of fence }\end{array}$

$10 / 29 / 2012<13.2>500<0.2 \quad 0.0 \quad$ Good Good debris line on law

$10 / 30 / 2012 \quad 13.0 \quad>500 \quad<0.2 \quad 0.0 \quad$ Fair $\quad \begin{array}{llll}13 & \text { Fair debris line on lawn }\end{array}$

1.0 Excellent Excellent seed line on wooden guard rat

$10 / 30 / 2012 \quad 16.9>500$

..9.

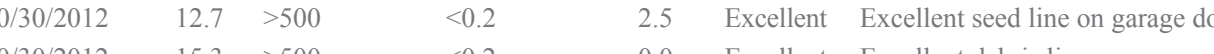

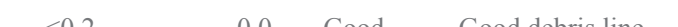

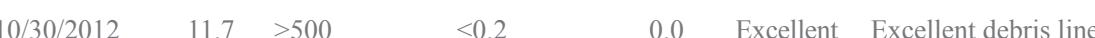

$\begin{array}{lllllll}10 / 30 / 2012 & 11.5 & >500 & <0.2 & 0.0 & \text { Fair } & \text { Fair debris line on lawn }\end{array}$

\begin{tabular}{lllllll}
$10 / 30 / 2012$ & 14.0 & $>500$ & $<0.2$ & 0.0 & Poor & Poor debris line in grass \\
\hline
\end{tabular}

\begin{tabular}{|c|c|c|c|c|c|c|}
\hline $10 / 30 / 2012$ & 9.7 & 90 & 1.1 & 2.1 & Excellent & Excellent seed line on side of fence \\
\hline 10/30/2012 & 9.9 & 70 & 1.4 & 0.0 & Good & Good mud line on concrete path \\
\hline 10/30/2012 & 10.6 & $<100$ & $>1$ & 1.0 & Good & Good seed line inside guard booth \\
\hline 10/30/2012 & 10.3 & 20 & 5.0 & 0.0 & Good & Good debris line in grass field \\
\hline 10/30/2012 & 10.7 & 30 & 3.3 & 3.4 & Fair & Fair debris line on fence \\
\hline 10/30/2012 & 10.4 & $<100$ & $>1$ & 0.0 & Good & Good debris line on grass \\
\hline 10/30/2012 & 10.2 & 20 & 5.0 & 0.0 & Good & Good debris line on grass \\
\hline 10/30/2012 & 11.3 & 100 & 1.0 & 0.4 & Good & Good seed line on inside door to shed \\
\hline 10/30/2012 & 10.9 & $>100 \&<500$ & $<1 \&>0.2$ & 2.2 & Good & Good mud line on door of building \\
\hline 10/30/2012 & 11.0 & $>100 \&<500$ & $<1 \&>0.2$ & 4.1 & Good & Good seed line on garage door of house \\
\hline 10/30/2012 & 11.3 & $>100 \&<500$ & $<1 \&>0.2$ & 4.4 & Good & Good seed line in window of Bubby's Restaurant and Bar \\
\hline 10/30/2012 & 11.2 & $>100 \&<500$ & $<1 \&>0.2$ & 2.6 & Good & Good seed line inside of office building \\
\hline 10/30/2012 & 11.2 & 100 & 1.0 & 4.1 & Good & Good mud line on metal door inside concrete building \\
\hline 10/30/2012 & 11.0 & $>100 \&<500$ & $<1 \&>0.2$ & 1.6 & Good & Good seed line on front of building \\
\hline 10/30/2012 & 10.9 & $>100 \&<500$ & $<1 \&>0.2$ & -- & Good & Good seed line on back of guard booth \\
\hline 10/29/2012 & 12.4 & $>100 \&<500$ & $<1 \&>0.2$ & -- & Excellent & Excellent mud line on outside of house \\
\hline 10/29/2012 & 11.3 & 100 & 1.0 & 3.6 & Good & Good seed line on side of building \\
\hline 10/29/2012 & 9.8 & 80 & 1.3 & 3.2 & Excellent & Excellent mud line on side of building \\
\hline
\end{tabular}


Table 7. Peak storm-tide elevations produced by Hurricane Sandy at 346 high-water-mark sites, and the corresponding Federal Emergency recurrence intervals) in New York.-Continued

[High-water-mark site locations are shown in figure 2. FEMA, Federal Emergency Management Agency; NAVD 88, North American Vertical Datum of 1988; no, number;

\begin{tabular}{|c|c|c|c|c|c|c|c|c|c|}
\hline & \multirow{2}{*}{\multicolumn{4}{|c|}{ Site }} & \multicolumn{5}{|c|}{$\begin{array}{l}\text { FEMA flood elevations for selected annual exceedance probabilities (recurrence intervals), } \\
\text { in feet above NAVD } 88\end{array}$} \\
\hline \multirow[b]{2}{*}{$\begin{array}{c}\text { Map } \\
\text { no. }\end{array}$} & & & & & \multicolumn{4}{|c|}{ Stillwater flood elevation } & \multirow{2}{*}{$\begin{array}{c}\text { 1-percent } \\
\text { (100-year) base flood } \\
\text { elevation }\end{array}$} \\
\hline & \multirow[t]{2}{*}{ Identifier } & $\begin{array}{c}\text { Latitude, } \\
\text { in decimal } \\
\text { degrees }\end{array}$ & $\begin{array}{l}\text { Longitude, } \\
\text { in decimal } \\
\text { degrees }\end{array}$ & $\begin{array}{c}\text { 'Coastal } \\
\text { flood } \\
\text { hazard zone }\end{array}$ & $\begin{array}{l}10 \text { percent } \\
\text { (10 year) }\end{array}$ & $\begin{array}{c}2 \text { percent } \\
\text { (50 year) }\end{array}$ & $\begin{array}{l}1 \text { percent } \\
\text { (100 year) }\end{array}$ & $\begin{array}{l}0.2 \text { percent } \\
\text { (500 year) }\end{array}$ & \\
\hline & & & & & & & & & ew York City—Continued \\
\hline 145 & HWM-NY-KIN-900 & 40.66725 & -74.00001 & $\mathrm{AE}$ & 6.6 & 9.7 & 11.2 & 14.7 & 12 \\
\hline 146 & HWM-NY-KIN-901 & 40.66111 & -74.00556 & $\mathrm{AE}$ & 6.9 & 9.7. & 11.2 & 14.6 & 12 \\
\hline 147 & HWM-NY-KIN-902 & 40.65583 & -74.01619 & $\mathrm{AE}$ & 6.7 & 9.9 & 11.3 & 14.8 & 13 \\
\hline 148 & HWM-NY-KIN-903 & 40.61089 & -74.03629 & $\mathrm{AE}$ & 7.1 & 10.0 & 11.3 & 14.7 & 11 \\
\hline 149 & HWM-NY-KIN-904 & 40.59519 & -74.00007 & $\mathrm{AE}$ & 7.0 & 9.8 & 10.8 & 14.5 & 11 \\
\hline 150 & HWM-NY-KIN-905 & 40.58019 & -73.99792 & $\mathrm{AE}$ & 7.0 & 9.7 & 11.0 & 14.2 & 12 \\
\hline 151 & HWM-NY-KIN-906 & 40.58940 & -73.92607 & $\mathrm{AE}$ & 6.6 & 9.5 & 10.5 & 13.6 & 10 \\
\hline 152 & HWM-NY-KIN-908 & 40.60743 & -73.89626 & $\mathrm{AE}$ & 6.7 & 9.1 & 10.2 & 13.0 & 11 \\
\hline 153 & HWM-NY-KIN-909 & 40.65948 & -73.86370 & $\mathrm{AE}$ & 6.5 & 9.0 & 10.3 & 13.0 & 10 \\
\hline 154 & HWM-NY-NEW-001 & 40.77760 & -73.94250 & $\mathrm{AE}$ & 8.2 & 10.8 & 11.9 & 14.6 & 15 \\
\hline 155 & HWM-NY-NEW-002 & 40.82800 & -73.95420 & $\mathrm{AE}$ & 5.8 & 8.4 & 9.7 & 12.9 & 10 \\
\hline 156 & HWM-NY-NEW-003 & 40.74070 & -74.01170 & VE & 6.6 & 9.4 & 10.9 & 14.3 & 16 \\
\hline 157 & HWM-NY-NEW-004 & 40.76312 & -74.00047 & $\mathrm{AE}$ & 6.6 & 9.2 & 10.6 & 14.1 & 12 \\
\hline 158 & HWM-NY-NEW-005 & 40.74013 & -73.97328 & $\mathrm{AE}$ & 7.0 & 9.7 & 10.9 & 14.0 & 12 \\
\hline 159 & HWM-NY-NEW-008 & 40.69035 & -74.04692 & VE & 6.9 & 10.0 & 11.4 & 15.0 & 14 \\
\hline 160 & HWM-NY-NEW-009 & 40.68971 & -74.04387 & $\mathrm{AE}$ & 6.9 & 9.9 & 11.3 & 14.7 & 12 \\
\hline 161 & HWM-NY-NEW-010 & 40.69912 & -74.03992 & $\mathrm{AE}$ & 6.9 & 9.8 & 11.3 & 14.9 & 12 \\
\hline 162 & HWM-NY-NEW-011 & 40.69938 & -74.03867 & VE & 6.9 & 10.3 & 11.3 & 14.7 & 13 \\
\hline 163 & HWM-NY-NEW-012 & 40.69086 & -74.01246 & $\mathrm{AE}$ & 6.9 & 9.7 & 11.1 & 14.7 & 12 \\
\hline 164 & HWM-NY-NEW-013 & 40.68527 & -74.02489 & $\mathrm{AE}$ & 6.9 & 9.8 & 11.2 & 14.8 & 12 \\
\hline 165 & HWM-NY-NEW-100 & 40.70110 & -74.01560 & $\mathrm{VE}$ & 6.9 & 9.9 & 11.4 & 15.0 & 16 \\
\hline 166 & HWM-NY-NEW-101 & 40.70110 & -74.01500 & VE & 6.9 & 9.9 & 11.3 & 14.9 & 14 \\
\hline 167 & HWM-NY-NEW-102 & 40.70440 & -74.01690 & $\mathrm{AE}$ & 6.5 & 9.9 & 11.2 & 14.8 & 12 \\
\hline 168 & HWM-NY-NEW-103 & 40.70440 & -74.01670 & $\mathrm{AE}$ & 6.5 & 9.9 & 11.1 & 14.8 & 12 \\
\hline 169 & HWM-NY-NEW-104 & 40.70310 & -74.00690 & $\mathrm{VE}$ & 6.8 & 9.8 & 11.2 & 14.8 & 15 \\
\hline 170 & HWM-NY-NEW-105 & 40.70500 & -74.00670 & $\mathrm{AE}$ & 6.6 & 9.8 & 11.2 & 14.8 & 12 \\
\hline 171 & HWM-NY-NEW-106 & 40.70500 & -74.00670 & $\mathrm{AE}$ & 6.6 & 9.8 & 11.2 & 14.8 & 12 \\
\hline 172 & HWM-NY-NEW-107 & 40.70500 & -74.00640 & $\mathrm{AE}$ & 6.6 & 9.8 & 11.2 & 14.8 & 12 \\
\hline 173 & HWM-NY-NEW-108 & 40.70780 & -74.00390 & $\mathrm{AE}$ & 6.6 & 9.8 & 11.2 & 14.7 & 12 \\
\hline 174 & HWM-NY-NEW-109 & 40.70780 & -74.00110 & $\mathrm{AE}$ & 6.7 & 9.7 & 11.1 & 14.6 & 12 \\
\hline 175 & HWM-NY-NEW-110 & 40.70780 & -74.00220 & $\mathrm{AE}$ & 6.7 & 9.8 & 11.2 & 14.6 & 12 \\
\hline 176 & HWM-NY-NEW-111 & 40.70780 & -74.00220 & $\mathrm{AE}$ & 6.7 & 9.8 & 11.2 & 14.6 & 12 \\
\hline 177 & HWM-NY-NEW-112 & 40.70970 & -73.99530 & $\mathrm{AE}$ & 6.8 & 9.7 & 11.0 & 14.5 & 13 \\
\hline 178 & HWM-NY-NEW-113 & 40.71080 & -73.97810 & $\mathrm{AE}$ & 6.8 & 9.6 & 10.8 & 13.9 & 12 \\
\hline 179 & HWM-NY-NEW-114 & 40.71080 & -73.97810 & $\mathrm{AE}$ & 6.8 & 9.6 & 10.8 & 13.9 & 12 \\
\hline 180 & HWM-NY-NEW-115 & 40.71080 & -73.97810 & $\mathrm{AE}$ & 6.8 & 9.6 & 10.8 & 13.9 & 12 \\
\hline 181 & HWM-NY-NEW-116 & 40.71110 & -73.97720 & VE & 6.9 & 9.6 & 10.9 & 13.9 & 14 \\
\hline 182 & HWM-NY-NEW-117 & 40.71110 & -73.97720 & VE & 6.9 & 9.6 & 10.9 & 13.9 & 14 \\
\hline 183 & HWM-NY-NEW-118 & 40.71110 & -73.97720 & $\mathrm{VE}$ & 6.9 & 9.6 & 10.9 & 13.9 & 14 \\
\hline 184 & HWM-NY-NEW-119 & 40.71110 & -73.97720 & VE & 6.9 & 9.6 & 10.9 & 13.9 & 14 \\
\hline 185 & HWM-NY-NEW-120 & 40.71640 & -74.01610 & $\mathrm{x}$ & -- & -- & -- & 14.5 & -- \\
\hline 186 & HWM-NY-NEW-121 & 40.71640 & -74.01670 & $\mathrm{x}$ & -- & -- & -- & 14.5 & -- \\
\hline 187 & HWM-NY-NEW-122 & 40.71810 & -74.01470 & $\mathrm{x}$ & -- & -- & -- & 14.4 & -- \\
\hline 188 & HWM-NY-NEW-123 & 40.71830 & -74.01500 & $\mathrm{x}$ & -- & -- & -- & 14.4 & -- \\
\hline 189 & HWM-NY-NEW-124 & 40.71690 & -74.01190 & $\mathrm{AE}$ & 6.5 & 9.7 & 10.8 & 14.3 & 11 \\
\hline
\end{tabular}

Management Agency flood elevations for the 10-, 2-, 1-, and 0.2-percent annual exceedance probabilities (10-, 50-, 100-, and 500-year

GMT, Grenwich Mean Time; $<$, less than; $>$ greater than; \&, and; --, no value; USGS, U.S. Geological Survey]

\section{Hurricane Sandy peak storm tide}

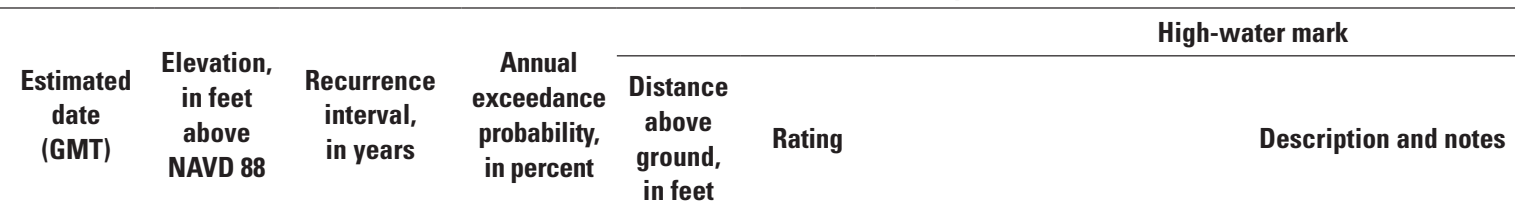

\begin{tabular}{|c|c|c|c|c|c|c|}
\hline 10/30/2012 & 11.0 & 90 & 1.1 & -- & Fair & Fair debris line on chain link fence \\
\hline 10/30/2012 & 11.2 & 100 & 1.0 & 3.0 & Fair & Fair wash line in compost \\
\hline 10/30/2012 & 11.5 & $>100 \&<500$ & $<1 \&>0.2$ & 4.5 & Fair & Fair seed line on trailer \\
\hline $10 / 30 / 2012$ & 12.9 & $>100 \&<500$ & $<1 \&>0.2$ & 0.0 & Poor & Poor debris line \\
\hline 10/30/2012 & 11.5 & $>100 \&<500$ & $<1 \&>0.2$ & 1.1 & Excellent & Excellent seed line on wall inside building \\
\hline $10 / 30 / 2012$ & 11.5 & $>100 \&<500$ & $<1 \&>0.2$ & 0.0 & Good & Good debris line around hill side \\
\hline $10 / 30 / 2012$ & 10.9 & $>100 \&<500$ & $<1 \&>0.2$ & 4.0 & Excellent & Excellent seed line on side of house \\
\hline $10 / 30 / 2012$ & 11.2 & $>100 \&<500$ & $<1 \&>0.2$ & 3.6 & Good & Good seed line on trailer \\
\hline 10/30/2012 & 10.0 & 90 & 1.1 & 1.1 & Excellent & Excellent mud line on inside of security hut \\
\hline 10/30/2012 & 10.4 & 40 & 2.5 & 2.4 & Poor & Poor debris line in ornamental grass \\
\hline 10/30/2012 & 9.5 & 90 & 1.1 & 0.0 & Fair & Fair debris line on lawn \\
\hline $10 / 30 / 2012$ & 12.3 & $<100$ & $>1$ & -- & Fair & Fair mud line on interior wall of fire house \\
\hline $10 / 30 / 2012$ & 10.4 & 90 & 1.1 & 2.6 & Excellent & Excellent seed line on building \\
\hline 10/30/2012 & 10.8 & 90 & 1.1 & 2.5 & Good & Good debris line on fence \\
\hline $10 / 30 / 2012$ & 11.3 & $<100$ & $>1$ & 4.1 & Excellent & Excellent seed line inside of maintenance room \\
\hline 10/30/2012 & 11.4 & $>100 \&<500$ & $<1 \&>0.2$ & 0.0 & Fair & Fair debris line near base of Statue of Liberty \\
\hline 10/30/2012 & 11.1 & 90 & 1.1 & -- & Good & Good seed line inside door of Immigration Museum \\
\hline 10/30/2012 & 11.1 & $<100$ & $>1$ & 0.0 & Poor & Poor debris line on grass hill \\
\hline 10/30/2012 & 11.0 & 100 & 1.0 & 2.5 & Excellent & Excellent seed line on glass door inside brick building \\
\hline $10 / 30 / 2012$ & 11.2 & 100 & 1.0 & 2.0 & Excellent & Excellent seed line inside shed \\
\hline 10/30/2012 & 11.6 & $<100$ & $>1$ & -- & Good & Good mud line on outside window of building \\
\hline 10/30/2012 & 11.4 & $<100$ & $>1$ & -- & Good & Good mud line on patio of building \\
\hline 10/30/2012 & 10.0 & 50 & 2.0 & -- & Good & Good mud line inside steel storage container \\
\hline 10/30/2012 & 11.0 & 100 & 1.0 & -. & Fair & Fair seed line on wooden construction wall \\
\hline 10/30/2012 & 11.3 & $<100$ & $>1$ & -- & Good & Good seed line inside window of ferry terminal building \\
\hline 10/30/2012 & 11.1 & 100 & 1.0 & -- & Fair & Fair seed line on outside wall of building \\
\hline $10 / 30 / 2012$ & 11.2 & 100 & 1.0 & .- & Fair & Fair seed line on outside wall of building \\
\hline 10/30/2012 & 11.2 & 100 & 1.0 & -- & Fair & Fair mud line on inside window of building \\
\hline $10 / 30 / 2012$ & 11.1 & 100 & 1.0 & -. & Good & Good seed line on outside door of Post Office \\
\hline 10/30/2012 & 11.0 & 100 & 1.0 & .- & Good & Good seed line on outside wall of building \\
\hline 10/30/2012 & 11.1 & 100 & 1.0 & -. & Good & Good mud line on outside door of building \\
\hline 10/30/2012 & 11.1 & 100 & 1.0 & -- & Excellent & Excellent mud line on outside window of building \\
\hline 10/30/2012 & 11.2 & $>100 \&<500$ & $<1 \&>0.2$ & $\ldots$ & Fair & Fair seed and mud line on outside wall of building \\
\hline $10 / 30 / 2012$ & 11.2 & $>100 \&<500$ & $<1 \&>0.2$ & 0.0 & Poor & Poor debris line on park lawn \\
\hline 10/30/2012 & 10.9 & $>100 \&<500$ & $<1 \&>0.2$ & 0.0 & Poor & Poor debris line on grass hill in park \\
\hline 10/30/2012 & 10.9 & $>100 \&<500$ & $<1 \&>0.2$ &.- & Fair & Fair seed line on tree in park \\
\hline 10/30/2012 & 10.9 & $<100$ & $>1$ & 0.0 & Poor & Poor debris line on grass hill in park \\
\hline $10 / 30 / 2012$ & 10.9 & $<100$ & $>1$ & 0.0 & Poor & Poor debris line on grass hill in park \\
\hline 10/30/2012 & 11.0 & $<100$ & $>1$ & 0.0 & Poor & Poor debris line on hill in park under tree \\
\hline 10/30/2012 & 10.9 & $<100$ & $>1$ & 0.0 & Fair & Fair debris line on park sidewalk \\
\hline $10 / 30 / 2012$ & 10.9 & $<500$ & $>0.2$ & 0.0 & Poor & Poor debris line on grass \\
\hline $10 / 30 / 2012$ & 10.9 & $<500$ & $>0.2$ & 0.0 & Poor & Poor wash line on mulch \\
\hline $10 / 30 / 2012$ & 11.3 & $<500$ & $>0.2$ & 0.0 & Poor & Poor debris line in garden \\
\hline $10 / 30 / 2012$ & 11.1 & $<500$ & $>0.2$ & 0.0 & & Poor debris line in garden \\
\hline 10/30/2012 & 10.9 & $>100 \&<500$ & $<1 \&>0.2$ & 1.0 & Excellent & Excellent seed line on loading dock \\
\hline
\end{tabular}


Table 7. Peak storm-tide elevations produced by Hurricane Sandy at 346 high-water-mark sites, and the corresponding Federal Emergency recurrence intervals) in New York.-Continued

[High-water-mark site locations are shown in figure 2. FEMA, Federal Emergency Management Agency; NAVD 88, North American Vertical Datum of 1988; no, number;

\begin{tabular}{cccccccccc}
\hline & & & \multicolumn{5}{c}{ FEMA flood elevations for selected annual exceedance probabilities (recurrence intervals), } \\
in feet above NAVD 88
\end{tabular}

\begin{tabular}{cccccccccc}
\hline & & & & & & \multicolumn{2}{c}{${ }^{12 N}$ New York City-Continued } \\
\hline 190 & HWM-NY-NEW-125 & 40.71690 & -74.01250 & AE & 6.5 & 9.7 & 10.9 & 14.4 & 11
\end{tabular}

$\begin{array}{llllllllll}190 & \text { HWM-NY-NEW-125 } & 40.71690 & -74.01250 & \text { AE } & 6.5 & 9.7 & 10.9 & 14.4 & 11 \\ 191 & \text { HWM-NY-NEW-126 } & 40.71640 & -74.01360 & \text { AE } & 6.7 & 9.7 & 10.8 & 14.4 & 11 \\ 192 & \text { HWM-NY-NEW-127 } & 40.71310 & -74.01390 & \text { AE } & 6.8 & 9.8 & 10.4 & 14.3 & 11\end{array}$

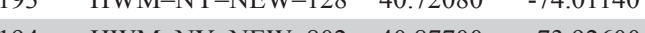

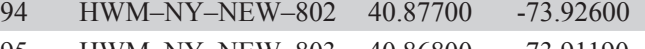

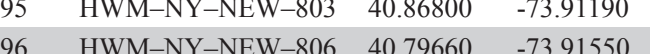

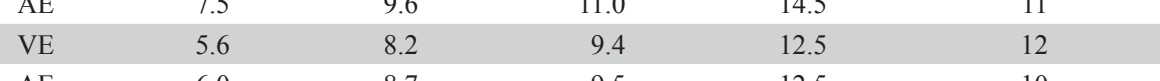

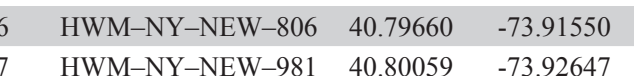

198 HWM-NY-QUE-001 $40.71556 \quad-73.92056$

HWM-NY-QUE-006 $40.74922 \quad-73.84072$

HWM-NY-QUE-007 $40.59296 \quad-73.79644$

HWM-NY-QUE-501 $40.77994 \quad-73.74918$

HWM-NY-QUE-502 $40.77994 \quad-73.74918$

$\begin{array}{llll}3 & \text { HWM-NY-QUE-503 } & 40.79284 & -73.84929 \\ \end{array}$

$\begin{array}{llll}\text { HWM-NY-QUE-505 } & 40.74169 & -73.95904 \\ \text { HWM-NY QUE 506 } & 40.77227 & -73.936\end{array}$

\begin{tabular}{llll} 
HWM-NY-QUE-506 & 40.77227 & -73.9360 \\
\hline
\end{tabular}

$\begin{array}{lll}\text { HWM-NY-QUE-508 } & 40.065267 & -73.84222\end{array}$

\begin{tabular}{lll} 
HWM-NY-QUE-509 & 40.78615 & -73.9153 \\
\hline
\end{tabular}

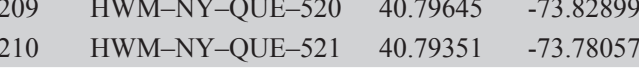

1 HWM-NY-QUE-603 40.75974 - 73.84864

$\begin{array}{lll}\text { HWM-NY-QUE-713 } & 40.61659 & -73.82547\end{array}$

$\begin{array}{lll}\text { HWM-NY-QUE-714 } & 40.60587 & -73.82204\end{array}$

\begin{tabular}{lll} 
HWM-NY-QUE-726 & 40.56779 & -73.88247 \\
\hline
\end{tabular}

\begin{tabular}{llll} 
HWM-NY-QUE-727 & 40.56537 & -73.8833 \\
\hline
\end{tabular}

$\begin{array}{lll}\text { HWM-NY-QUE-728 } & 40.56111 & -73.9143 \\ \text { HWM-NY-QUE-729 } & 40.55532 & -73.9252\end{array}$

HWM-NY-QUE-730 $40.57632 \quad-73.85982$

HWM-NY-QUE-731 $40.58243-73.8345$

$\begin{array}{lll}\text { HWM-NY-QUE-732 } & 40.59512 & -73.74139\end{array}$

HWM-NYQUE-907 $40.56704-73.88283$

HWM-NY-NIC-001 $40.59244-74.16830$

$\begin{array}{lll}\text { HWM-NY-RIC-701 } & 40.58222 & -74.0985\end{array}$

$\begin{array}{lll}\text { HWM-NY-RIC-702 } & 40.50242 & -74.25388\end{array}$

$\begin{array}{llll}\text { HWM-NY-RIC-703 } & 40.49965 & -74.24120\end{array}$

\begin{tabular}{llll} 
HWM-NY-RIC-704 & 40.50235 & -74.2312 \\
\hline
\end{tabular}

\begin{tabular}{llll} 
HWM-NY-RIC-705 & 40.51544 & -74.19444 \\
\hline
\end{tabular}

$\begin{array}{llll}\text { HWM-NY-RIC-716 } & 40.51153 & -74.21036 \\ \text { HWM-NY-RIC-717 } & 40.52844 & -74.1588\end{array}$

HWM-NY-RIC-718 $40.55526 \quad-74.11662$

\begin{tabular}{llll} 
HWM-NY-RIC-719 & 40.59386 & -74.06829 \\
\hline
\end{tabular}

\begin{tabular}{|c|c|c|c|c|c|}
\hline $\mathrm{AE}$ & 6.9 & 8.9 & 10.1 & 12.7 & 10 \\
\hline $\mathrm{AE}$ & 9.2 & 10.9 & 11.5 & 12.6 & 12 \\
\hline $\mathrm{AE}$ & 6.5 & 8.3 & 9.2 & 11.8 & 9 \\
\hline $\mathrm{AE}$ & 9.7 & 11.8 & 12.7 & 14.4 & 14 \\
\hline $\mathrm{AE}$ & 9.7 & 11.8 & 12.7 & 14.4 & 14 \\
\hline $\mathrm{AE}$ & 9.7 & 12.0 & 13.0 & 15.0 & 14 \\
\hline $\mathrm{AE}$ & 6.9 & 9.6 & 10.8 & 13.7 & 11 \\
\hline $\mathrm{AE}$ & 8.0 & 10.5 & 11.6 & 14.2 & 12 \\
\hline $\mathrm{AE}$ & 6.5 & 8.8 & 9.9 & 12.8 & 10 \\
\hline $\mathrm{AE}$ & 6.5 & 8.7 & 9.8 & 12.5 & 10 \\
\hline $\mathrm{AE}$ & 9.0 & 11.4 & 12.5 & 14.9 & 14 \\
\hline VE & 9.7 & 11.9 & 12.8 & 14.7 & 15 \\
\hline VE & 9.8 & 12.1 & 12.9 & 14.8 & 16 \\
\hline $\mathrm{AE}$ & 9.7 & 12.0 & 12.9 & 14.9 & 14 \\
\hline $\mathrm{x}$ &.- & -- & -- & 12.0 & -- \\
\hline $\mathrm{AE}$ & 6.3 & 8.7 & 9.6 & 12.0 & 10 \\
\hline $\mathrm{AE}$ & 6.7 & 8.7 & 9.9 & 12.7 & 11 \\
\hline $\mathrm{x}$ & 6.7 & 8.7 & 9.8 & 13.0 & -- \\
\hline $\mathrm{AE}$ & 6.7 & 9.3 & 10.6 & 13.7 & 12 \\
\hline $\mathrm{AE}$ & 6.5 & 9.5 & 11.0 & 14.7 & 11 \\
\hline $\mathrm{AE}$ & 6.6 & 8.9 & 10.0 & 12.6 & 10 \\
\hline $\mathrm{AE}$ & 6.5 & 8.6 & 9.6 & 12.1 & 10 \\
\hline $\mathrm{AE}$ & 6.0 & 8.5 & 10.0 & 14.0 & 11 \\
\hline $\mathrm{AE}$ & 6.7 & 8.5 & 9.8 & 12.7 & 11 \\
\hline $\mathrm{AE}$ & 6.3 & 8.4 & 9.4 & 11.8 & 10 \\
\hline $\mathrm{AE}$ & 7.3 & 10.2 & 11.6 & 14.7 & 12 \\
\hline $\mathrm{AE}$ & 7.2 & 10.6 & 11.7 & 15.9 & 12 \\
\hline $\mathrm{x}$ & -- & -- & -- & 16.5 & -- \\
\hline $\mathrm{AE}$ & 8.7 & 11.3 & 13.0 & 16.7 & 14 \\
\hline $\mathrm{X}$ & -- & -- & -- & 16.3 & -- \\
\hline $\mathrm{x}$ & -- & -- & -- & 16.3 & -- \\
\hline $\mathrm{x}$ & -- & -- & -- & 16.2 & -- \\
\hline $\mathrm{x}$ & -- & -- & -- & 15.8 & -- \\
\hline $\mathrm{AE}$ & 7.4 & 10.4 & 11.9 & 15.8 & 13 \\
\hline $\mathrm{X}$ & -- & -- & -- & 15.5 & -- \\
\hline $\mathrm{X}$ & -- & -- & -- & 14.7 & -- \\
\hline
\end{tabular}

Management Agency flood elevations for the 10-, 2-, 1-, and 0.2-percent annual exceedance probabilities (10-, 50-, 100-, and 500-year

GMT, Grenwich Mean Time; $<$ less than; $>$, greater than; \&, and; --, no value; USGS, U.S. Geological Survey

Hurricane Sandy peak storm tide

High-water mark

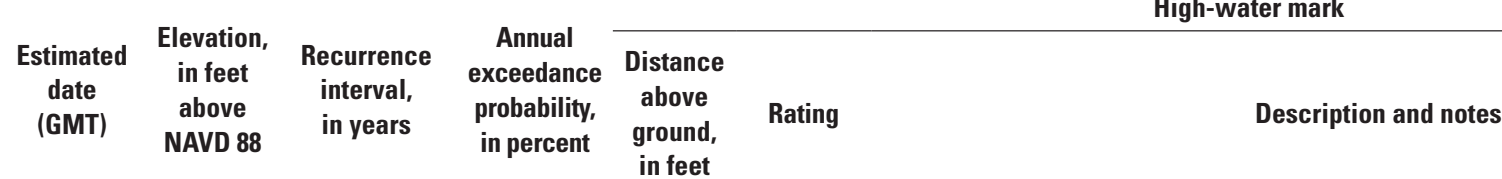

\begin{tabular}{|c|c|c|c|c|c|c|}
\hline 10/30/2012 & 10.6 & 90 & 1.1 & 1.5 & Fair & Fair seed line on outside door of building \\
\hline $10 / 30 / 2012$ & 9.8 & 50 & 2.0 & 4.3 & Good & Good seed line on outside wall of building \\
\hline 10/30/2012 & 9.7 & 50 & 2.0 & 4.7 & Good & Good mud line on window of building \\
\hline $10 / 30 / 2012$ & 10.8 & 90 & 1.1 & 1.0 & Excellent & Excellent mud line on outside door of building \\
\hline $10 / 30 / 2012$ & 9.5 & $<100$ & $>1$ & 0.0 & Good & Good debris line on beach \\
\hline 10/30/2012 & 9.0 & 70 & 1.4 & 2.1 & Excellent & Excellent seed line on guard booth \\
\hline 10/30/2012 & 11.1 & $<100$ & $>1$ & 3.1 & Fair & Fair debris line on side of fence \\
\hline 10/30/2012 & 10.3 & 50 & 2.0 & 3.8 & Fair & $\begin{array}{l}\text { Fair seed line inside storage container inside chain link fenced area of New York Police } \\
\text { Department marina }\end{array}$ \\
\hline 10/30/2012 & 10.9 & $>100 \&<500$ & $<1 \&>0.2$ & 6.0 & Excellent & Excellent mud line on door of storage container \\
\hline 10/30/2012 & 7.8 & $<10$ & $>10$ & 0.0 & Fair & Fair debris line on lawn \\
\hline 10/30/2012 & 10.7 & $>100 \&<500$ & $<1 \&>0.2$ & 4.5 & Good & Good debris line on fence \\
\hline 10/30/2012 & 10.3 & 20 & 5.0 & 3.5 & Good & Good seed line on power pole in park \\
\hline 10/30/2012 & 10.3 & 20 & 5.0 & 2.1 & Good & Good seed line on house garage \\
\hline 10/30/2012 & 10.1 & 20 & 5.0 & 0.0 & Good & Good wash line in park \\
\hline $10 / 30 / 2012$ & 10.7 & 100 & 1.0 & 5.0 & Good & Good seed line on Amtrak facility \\
\hline 10/30/2012 & 10.9 & 70 & 1.4 & 4.0 & Good & Good seed line on windows and brick of apartment building \\
\hline 10/30/2012 & 10.9 & $>100 \&<500$ & $<1 \&>0.2$ & 2.5 & Good & Good seed line on fence \\
\hline 10/30/2012 & 10.8 & $>100 \&<500$ & $<1 \&>0.2$ & 2.7 & Good & Good seed line on fence \\
\hline $10 / 30 / 2012$ & 10.5 & 30 & 3.3 & 0.0 & Poor & Poor wash line on green space in park \\
\hline $10 / 30 / 2012$ & 10.8 & $<100$ & $>1$ & 0.3 & Poor & Poor debris line on seawall \\
\hline $10 / 30 / 2012$ & 10.6 & $<100$ & $>1$ & 0.0 & Poor & Poor debris line on grass \\
\hline $10 / 30 / 2012$ & 10.5 & 20 & 5.0 & 0.0 & Poor & Poor debris line in parking lot \\
\hline 10/29/2012 & 10.3 & $<500$ & $>0.2$ & 0.0 & Good & Good debris line \\
\hline 10/29/2012 & 10.3 & $>100 \&<500$ & $<1 \&>0.2$ & 1.3 & Excellent & Excellent mud line on wall inside house \\
\hline $10 / 30 / 2012$ & 10.5 & $>100 \&<500$ & $<1 \&>0.2$ & 0.0 & Excellent & Excellent debris line \\
\hline 10/30/2012 & 10.8 & $>100 \&<500$ & $<1 \&>0.2$ & 0.0 & Fair & Fair debris line in parking lot \\
\hline $10 / 29 / 2012$ & 10.7 & $>100 \&<500$ & $<1 \&>0.2$ & 3.6 & Excellent & Excellent mud line on wall inside building \\
\hline $10 / 30 / 2012$ & 12.7 & $>100 \&<500$ & $<1 \&>0.2$ & 5.4 & Excellent & Excellent mud line on side of house \\
\hline $10 / 30 / 2012$ & 11.2 & $>100 \&<500$ & $<1 \&>0.2$ & 5.4 & Excellent & Excellent wash line in front of building \\
\hline $10 / 30 / 2012$ & 10.3 & $>100 \&<500$ & $<1 \&>0.2$ & -- & Fair & Fair mud line on wall \\
\hline 10/30/2012 & 9.0 & 70 & 1.4 & -- & Good & Good seed line on side of building \\
\hline $10 / 30 / 2012$ & 11.0 & $>100 \&<500$ & $<1 \&>0.2$ & 4.2 & Excellent & Excellent seed line on inside of doorway \\
\hline $10 / 30 / 2012$ & 10.6 & $>100 \&<500$ & $<1 \&>0.2$ & 4.6 & Good & Good seed line on inside side of concrete wall \\
\hline $10 / 30 / 2012$ & 12.3 & $>100 \&<500$ & $<1 \&>0.2$ & 4.3 & Excellent & Excellent seed line on wall of garage \\
\hline $10 / 30 / 2012$ & 12.5 & $>100 \&<500$ & $<1 \&>0.2$ & 4.7 & Fair & Fair seed line on side of fence \\
\hline $10 / 30 / 2012$ & 13.1 & $<500$ & $>0.2$ & 0.0 & Good & Good debris line on grass \\
\hline 10/29/2012 & 13.2 & $>100 \&<500$ & $<1 \&>0.2$ & 5.5 & Fair & Fair seed line on side of fence \\
\hline 10/29/2012 & 13.2 & $<500$ & $>0.2$ & 0.0 & Good & Good debris line on lawn \\
\hline 10/30/2012 & 13.0 & $<500$ & $>0.2$ & 0.0 & Fair & Fair debris line on lawn \\
\hline 10/30/2012 & 13.1 & $<500$ & $>0.2$ & 1.0 & Excellent & Excellent seed line on wooden guard rail \\
\hline 10/30/2012 & 16.9 & $>500$ & $<0.2$ & 0.0 & Fair & Fair debris line on grass \\
\hline $10 / 30 / 2012$ & 12.5 & $>100 \&<500$ & $<1 \&>0.2$ & 7.9 & Excellent & Excellent seed line on door frame of house \\
\hline 10/30/2012 & 12.7 & $<500$ & $>0.2$ & 2.5 & Excellent & nt seed line on garage door \\
\hline $10 / 30 / 2012$ & 15.3 & $>500$ & $<0.2$ & 0.0 & Excellent & Excellent debris line \\
\hline
\end{tabular}


Table 7. Peak storm-tide elevations produced by Hurricane Sandy at 346 high-water-mark sites, and the corresponding Federal Emergency recurrence intervals) in New York.-Continued

[High-water-mark site locations are shown in figure 2. FEMA, Federal Emergency Management Agency; NAVD 88, North American Vertical Datum of 1988; no, number;

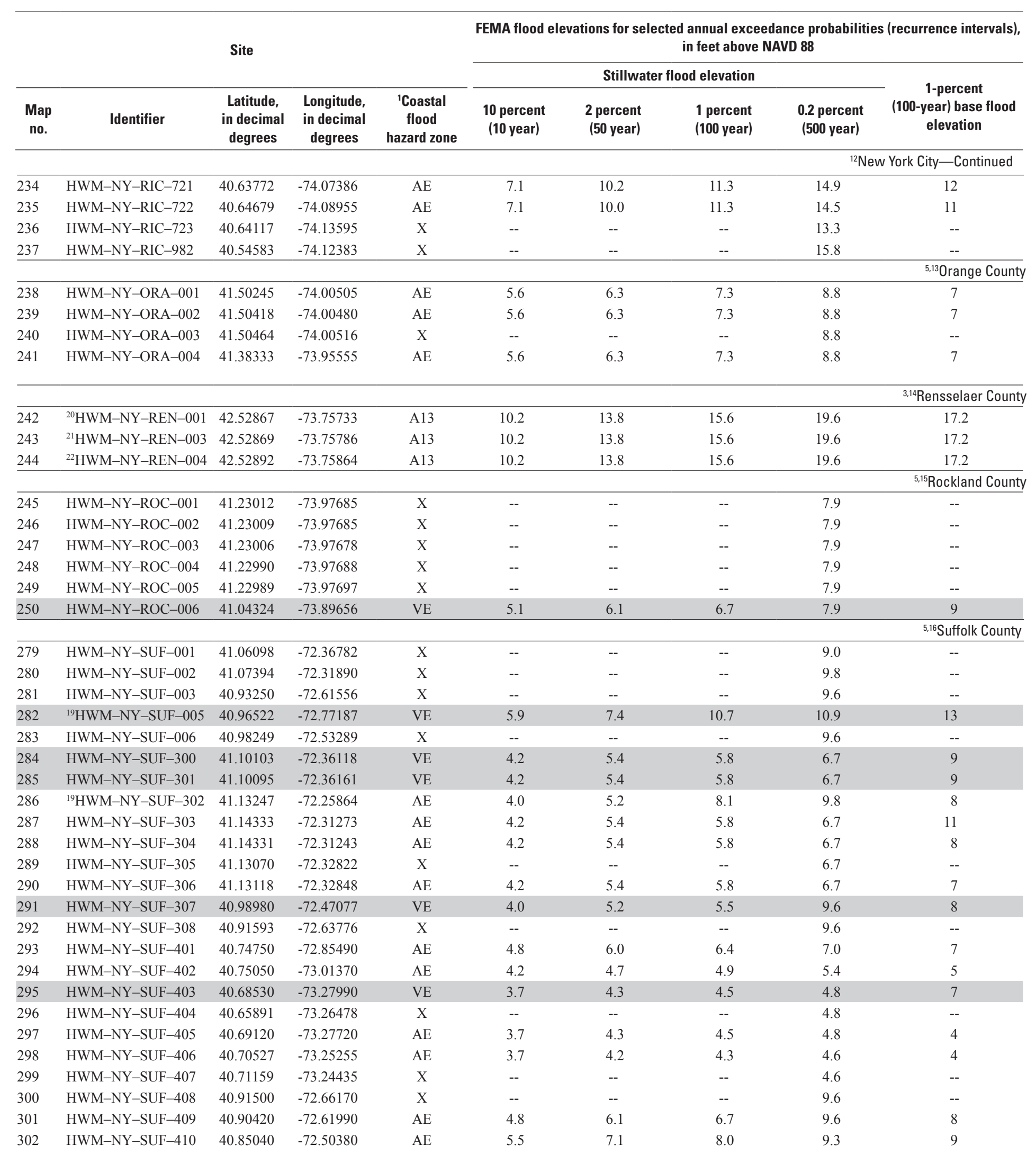

Management Agency flood elevations for the 10-, 2-, 1-, and 0.2-percent annual exceedance probabilities (10-, 50-, 100-, and 500-year

GMT, Grenwich Mean Time; $<$ less than; $>$, greater than; \&, and; --, no value; USGS, U.S. Geological Survey

Hurricane Sandy peak storm tide

High-water mark

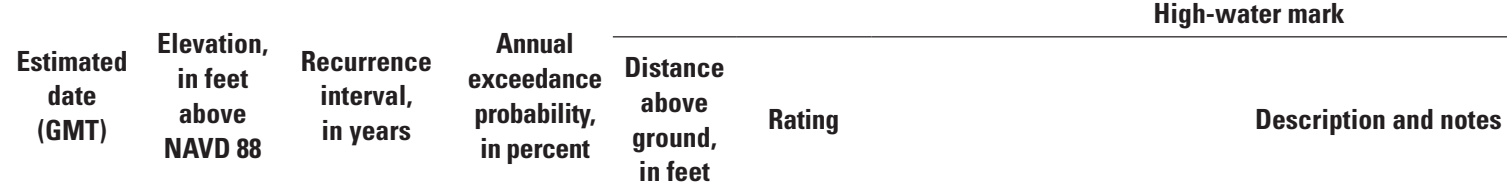

\begin{tabular}{lllllll}
\hline $10 / 30 / 2012$ & 11.7 & $>100 \&<500$ & $<1 \&>0.2$ & 0.0 & Good & Good debris line
\end{tabular}

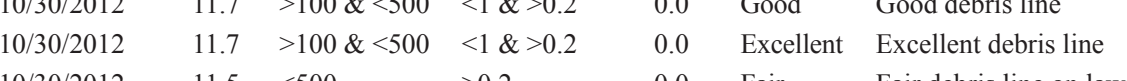

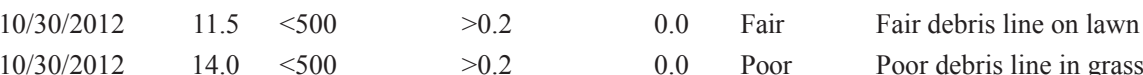

$\begin{array}{lllllll}10 / 30 / 2012 & 8.9 & >500 & <0.2 & 1.9 & \text { Good } & \text { Good mud line on door of marina office building }\end{array}$

$\begin{array}{llllll}10 / 30 / 2012 & 8.9 & >500 & <0.2 & 3.0 & \text { Good } \quad \text { Good seed line on inside of door to restroom of Newburgh Marina }\end{array}$

\begin{tabular}{lllllll}
$10 / 30 / 2012$ & 9.0 & $>500$ & $<0.2$ & 0.0 & Fair $\quad$ Fair wash line on ground in parking lot divider \\
\hline
\end{tabular}

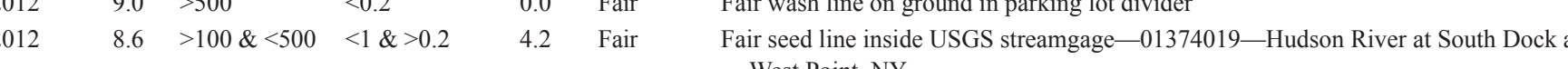

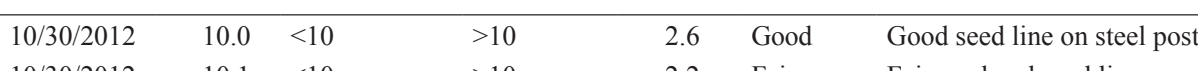

$\begin{array}{llllll}10 / 30 / 2012 & 10.1 & <10 & >10 & 2.2 & \text { Fair }\end{array} \quad$ Fair seed and mud line on small shed

\begin{tabular}{lllllll}
$10 / 30 / 2012$ & 9.9 & $<10$ & $>10$ & 0.0 & Poor & Poor debris line on grass \\
\hline
\end{tabular}

\begin{tabular}{lrlllll}
\hline $10 / 30 / 2012$ & 10.3 & $>500$ & $<0.2$ & 0.0 & Poor & Poor debris line on ground \\
10302012 & 9.4 & $>500$ & $<0.2$ & 2.0 & Fair & Fair seed line bof
\end{tabular}

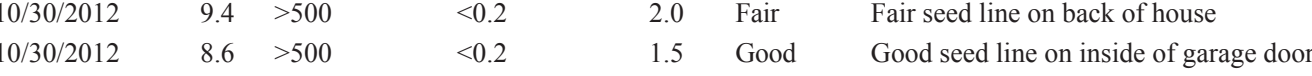

$\begin{array}{llllll}10 / 30 / 2012 & 9.4 & >500 & <0.2 & - & \text { Excellent Excellent seed line on back of house in protected alcove }\end{array}$

\begin{tabular}{rrrrrrr}
$10 / 30 / 2012$ & 11.1 & $>500$ & $<0.2$ & 0.0 & Poor & Poor debris line on ground \\
$10 / 30 / 2012$ & 9.7 & $>100$ & $<1$ & 4.1 & Good & Good seed line on interior wall of concrete instrument shelter \\
\hline
\end{tabular}

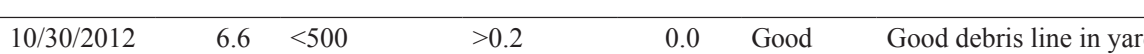

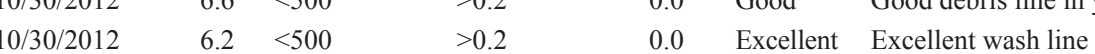

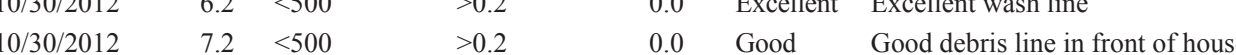

$\begin{array}{lllllll}10 / 29 / 2012 & 9.1 & <100 & >1 & 3.6 & \text { Excellent } & \text { Excellent mud line on garage door of house }\end{array}$

$\begin{array}{lllllll}10 / 29 / 2012 & 6.7 & <500 & >0.2 & 0.0 & \text { Good } & \text { Good wash line on lawn }\end{array}$

\begin{tabular}{llllllll}
$10 / 29 / 2012$ & 6.4 & $<100$ & $>1$ & 0.0 & Good & Good debris line \\
\hline
\end{tabular}

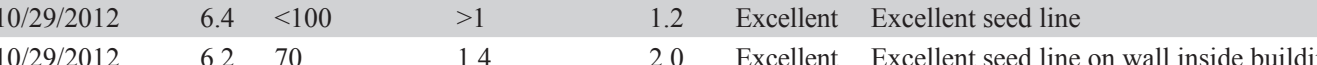

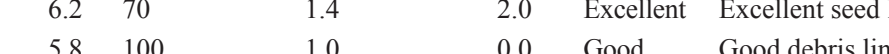

$\begin{array}{llllll}1.8292012 & 5.8 & 100 & 1.0 & 0.0 & \text { Good } \quad \text { Good debris line }\end{array}$

\begin{tabular}{llllll}
$10 / 29 / 2012$ & 7.0 & $>500$ & $<0.2$ & 1.2 & Excellent \\
\hline
\end{tabular}

$\begin{array}{lllll} & \end{array}$

$\begin{array}{lllllll}10 / 29 / 2012 & 7.1 & <100 & >1 & 1.3 & \text { Excellent } & \text { Excellent seed line on back of house }\end{array}$

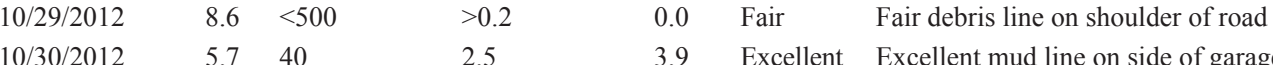

$\begin{array}{lllllll}10 / 202012 & 5.7 & 40 & 2.5 & 3.9 & \text { Excellent } & \text { Excellent mud line on side of garage } \\ 10 / 302012 & 5.8 & >500 & <0.2 & 1.6 & \text { Excellent } & \text { Excellent mud line on side of shed }\end{array}$

$\begin{array}{llllllll}10 / 30 / 2012 & 7.4 & >100 & <1 & 0.0 & \text { Poor } & \text { Poor debris line on grassy embankment }\end{array}$

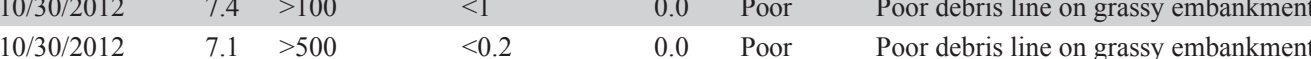

$\begin{array}{lllllll}10 / 29 / 2012 & 5.8 & >500 & <0.2 & 2.9 & \text { Excellent Excellent mud line on side of fence }\end{array}$

\begin{tabular}{llllll}
$10 / 29 / 2012$ & 6.0 & $>500$ & $<0.2$ & 1.8 & Excellent \\
\hline
\end{tabular}

$\begin{array}{lllllll}10 / 29 / 2012 & 6.1 & >500 & <0.2 & 1.1 & \text { Excellent } & \text { Excellent mud line on front of building }\end{array}$

$\begin{array}{lllllll}10 / 29 / 2012 & 7.8 & <500 & >0.2 & 0.8 & \text { Good } \quad \text { Good seed line on front of house }\end{array}$

$\begin{array}{lllllll}10 / 30 / 2012 & 7.7 & >100 \&<500 & <1 \&>0.2 & 0.5 & \text { Excellent Excellent seed line inside building }\end{array}$

$\begin{array}{lllllll}10 / 29 / 2012 & 6.6 & 40 & 2.5 & 1.5 & \text { Excellent } & \text { Excellent seed line on outside of building }\end{array}$ 
Table 7. Peak storm-tide elevations produced by Hurricane Sandy at 346 high-water-mark sites, and the corresponding Federal Emergency recurrence intervals) in New York.-Continued

[High-water-mark site locations are shown in figure 2. FEMA, Federal Emergency Management Agency; NAVD 88, North American Vertical Datum of 1988; no, number;

\begin{tabular}{cccccccccc}
\hline & & & \multicolumn{5}{c}{ FEMA flood elevations for selected anual exceedance probabilities (recurrence intervals) } \\
in feet above NAVD 88
\end{tabular}

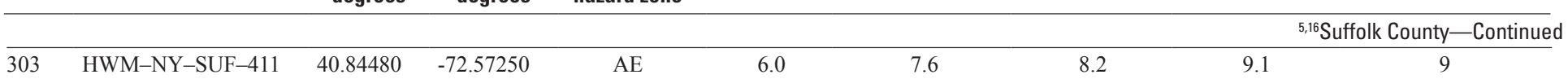

$\begin{array}{llll}303 & \text { HWM-NY-SUF-411 } & 40.84480 & -72.57250 \\ 304 & \text { HWM-NY-SUF-412 } & 40.81890 & -72.62450\end{array}$

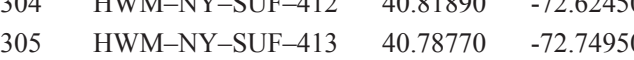

$\begin{array}{llll}306 & \text { HWM-NY-SUF-415 } & 40.77410 & -72.81610 \\ 307 & \text { HWM-NY-SUF-417 } & 40.66300 & -73.4130\end{array}$

\begin{tabular}{llll}
307 & HWM-NY-SUF-417 & 40.66300 & -73.41300 \\
\hline 08 & $19 \mathrm{HWM}-\mathrm{NY}-\mathrm{SUF}-418$ & 40.63213 & -73.21621
\end{tabular}

$\begin{array}{llll}308 & { }^{10} \mathrm{HWM}-\mathrm{NY}-\mathrm{SUF}-418 & 40.63213 & -73.21621 \\ 309 & { }^{10} \mathrm{HWM}-\mathrm{NY}-\mathrm{SUF}-419 & 40.64400 & -73.15700\end{array}$

$\begin{array}{llll}309 & { }^{10} \mathrm{HWM}-\mathrm{NY}-\mathrm{SUF}-419 & 40.64400 & -73.15700 \\ 310 & { }^{10} \mathrm{HWM}-\mathrm{NY}-\mathrm{SUF}-420 & 40.63455 & -73.2030\end{array}$

$311 \quad$ HWM-NY-SUF-421 $40.87980-72.44990$

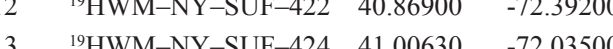

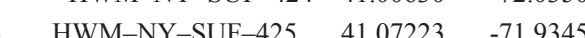

$\begin{array}{lll}{ }^{19} \mathrm{HWM}-\mathrm{NY}-\mathrm{SUF}-426 & 41.05010 & -71.95650\end{array}$

HWM-NY-SUF-427 $41.00390 \quad-72.18660$

$\begin{array}{llll}\text { HWM-NY-SUF-428 } & 41.00100 & -72.29100 \\ \text { HWM-NY-SUF-429 } & 41.01360 & -7230320\end{array}$

$\begin{array}{llll} & \text { HWM-NY-SUF-430 } & 41.03710 & -72.31970\end{array}$

320 HWM-NY-SUF-431 $40.99290 \quad-72.31550$

HWM-NY-SUF-432 $40.99370 \quad-72.3629$

HWM-NY-SUF-433 $40.95980-72.39820$

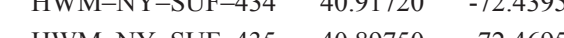

\begin{tabular}{llll}
\hline &
\end{tabular}

$\begin{array}{llll}{ }^{19 H W M} \text { HWY-SUF-506 } & 40.96452 & -72.86320\end{array}$

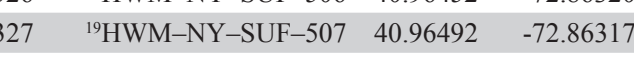

$\begin{array}{llll}328 & \text { HWM-NY-SUF-508 } & 40.94574 & -73.07198\end{array}$

$\begin{array}{llll}\text { HWM-NY-SUF-509 } & 40.94574 & -73.07198\end{array}$

HWM-NY-SUF-510 $40.95115 \quad-73.0294$

\begin{tabular}{ccc} 
HWM-NY-SUF-511 & 41.01220 & -72.55640 \\
\hline HWM-NY SUF 512 & 40.91617 & -726619
\end{tabular}

$\begin{array}{llll}\text { HWM-NY-SUF-513 } & 40.91617 & -72.66119\end{array}$

\begin{tabular}{llll} 
HWM-NY-SUF-514 40.91746 & -72.65535 \\
\hline
\end{tabular}

\begin{tabular}{llll} 
HWM-NYSSUF-516 & 40.91010 & -72.55543 \\
\hline
\end{tabular}

\begin{tabular}{llll}
336 & HWM-NY-SUF-517 & 40.90030 & -72.35303 \\
\hline $3 W$ & HW-NY SUF 600 & 40.74760 & -73.15039
\end{tabular}

338 HWM-NY-SUF-601 $40.92202 \quad-73.44324$

$339 \quad{ }^{19 H W M-N Y-S U F-602} \quad 40.90728 \quad-73.48357$

340 HWM-NY-SUF-603 $40.89717 \quad-73.43498$

\begin{tabular}{llll}
341 & HWM-NY-SUF-604 & 40.90536 & -73.40283 \\
\hline
\end{tabular}

$\begin{array}{llll} & 19 \\ \end{array}$

3 HWM-NY-SUF-606 $40.92593 \quad-73.3571$

$\begin{array}{llll}\text { HWM-NY-SUF-607 } & 40.95410 & -73.39812 \\ \text { I9HWM-NY-SUF-608 } & 40.92305 & -73.2963\end{array}$

\begin{tabular}{llll}
\hline HWM-NY-SUF-609 & 40.89697 & -73.223 \\
\hline
\end{tabular}

$\begin{array}{llll}\text { NWM-NY-SUF-609 } & 40.89697 & -73.22364 \\ \text { HWM-NY-SUF- } 610 & 40.92173 & -73.14967\end{array}$

\begin{tabular}{|c|c|c|c|c|c|}
\hline $\mathrm{AE}$ & 6.0 & 7.6 & 8.2 & 9.1 & 9 \\
\hline $\mathrm{AE}$ & 5.6 & 7.2 & 7.7 & 8.7 & 9 \\
\hline $\mathrm{AE}$ & 5.0 & 6.2 & 6.8 & 7.8 & 7 \\
\hline $\mathrm{AE}$ & 5.2 & 6.5 & 6.9 & 7.5 & 8 \\
\hline $\mathrm{AE}$ & 5.0 & 6.0 & 6.3 & 6.8 & 6 \\
\hline $\mathrm{AE}$ & 4.3 & 4.8 & 8.0 & 5.2 & 9 \\
\hline $\mathrm{VE}$ & 6.5 & 8.5 & 14.1 & 11.5 & 16 \\
\hline $\mathrm{AE}$ & 4.3 & 4.8 & 8.0 & 5.2 & 10 \\
\hline $\mathrm{AE}$ & 5.3 & 7.4 & 8.6 & 10.3 & 9 \\
\hline $\mathrm{AE}$ & 5.9 & 8.4 & 14.4 & 12.7 & 14 \\
\hline $\mathrm{AE}$ & 3.5 & 4.9 & 8.0 & 7.2 & 10 \\
\hline $\mathrm{x}$ & -- & -- & -- & 7.2 & - \\
\hline $\mathrm{AE}$ & 3.5 & 4.9 & 7.9 & 7.2 & 10 \\
\hline $\mathrm{AE}$ & 3.5 & 4.9 & 5.3 & 7.2 & 6 \\
\hline $\mathrm{AE}$ & 5.2 & 6.2 & 6.5 & 9.8 & 7 \\
\hline $\mathrm{AE}$ & 4.0 & 5.2 & 5.9 & 9.4 & 6 \\
\hline $\mathrm{AE}$ & 4.0 & 5.2 & 5.9 & 9.4 & 6 \\
\hline $\mathrm{VE}$ & 4.0 & 5.2 & 5.5 & 9.6 & 8 \\
\hline $\mathrm{AE}$ & 4.0 & 5.2 & 5.5 & 9.6 & 7 \\
\hline $\mathrm{AE}$ & 4.0 & 5.2 & 5.5 & 9.6 & 6 \\
\hline $\mathrm{AE}$ & 4.0 & 5.2 & 5.5 & 9.6 & 7 \\
\hline $\mathrm{AE}$ & 4.0 & 5.2 & 5.5 & 9.6 & 6 \\
\hline $\mathrm{AE}$ & 4.0 & 5.2 & 5.5 & 9.6 & 6 \\
\hline $\mathrm{AE}$ & 5.9 & 7.4 & 10.5 & 10.8 & 12 \\
\hline $\mathrm{VE}$ & 5.9 & 7.4 & 10.5 & 10.8 & 13 \\
\hline $\mathrm{AE}$ & 6.8 & 7.7 & 8.2 & 9.0 & 10 \\
\hline $\mathrm{AE}$ & 6.8 & 7.7 & 8.2 & 9.0 & 10 \\
\hline $\mathrm{AE}$ & 6.5 & 8.2 & 8.8 & 10.4 & 11 \\
\hline $\mathrm{AE}$ & 6.2 & 7.5 & 10.8 & 9.4 & 11 \\
\hline $\mathrm{AE}$ & 4.8 & 6.1 & 6.7 & 9.6 & 7 \\
\hline $\mathrm{AE}$ & 4.8 & 6.1 & 6.7 & 9.6 & 7 \\
\hline $\mathrm{AE}$ & 4.8 & 6.1 & 6.7 & 9.6 & 8 \\
\hline $\mathrm{x}$ & -- & -- & -- & 9.6 & \\
\hline $\mathrm{VE}$ & 7.1 & 8.2 & 8.9 & 10.5 & 12 \\
\hline $\mathrm{AE}$ & 4.2 & 4.6 & 4.8 & 5.2 & 5 \\
\hline $\mathrm{x}$ & -- & -- & -- & 10.5 & $\ldots$ \\
\hline $\mathrm{VE}$ & 7.3 & 8.6 & 10.9 & 11.0 & 13 \\
\hline $\mathrm{AE}$ & 7.1 & 8.2 & 8.9 & 10.5 & 11 \\
\hline $\mathrm{AE}$ & 7.1 & 8.2 & 8.9 & 10.5 & 11 \\
\hline $\mathrm{AE}$ & 7.1 & 8.2 & 9.4 & 10.5 & 10 \\
\hline $\mathrm{AE}$ & 7.1 & 8.2 & 8.9 & 10.5 & 11 \\
\hline $\mathrm{AE}$ & 7.1 & 8.2 & 8.9 & 10.5 & 12 \\
\hline $\mathrm{AE}$ & 7.1 & 8.2 & 11.2 & 10.5 & 11 \\
\hline & 6.9 & 8.3 & 8.8 & 10.4 & 10 \\
\hline $\mathrm{AE}$ & 6.8 & 8.2 & 8.7 & 10.3 & 10 \\
\hline
\end{tabular}

Management Agency flood elevations for the 10-, 2-, 1-, and 0.2-percent annual exceedance probabilities (10-, 50-, 100-, and 500-year

GMT, Grenwich Mean Time; $<$ less than; $>$, greater than; \&, and; --, no value; USGS, U.S. Geological Survey]

Hurricane Sandy peak storm tide

High-water mark

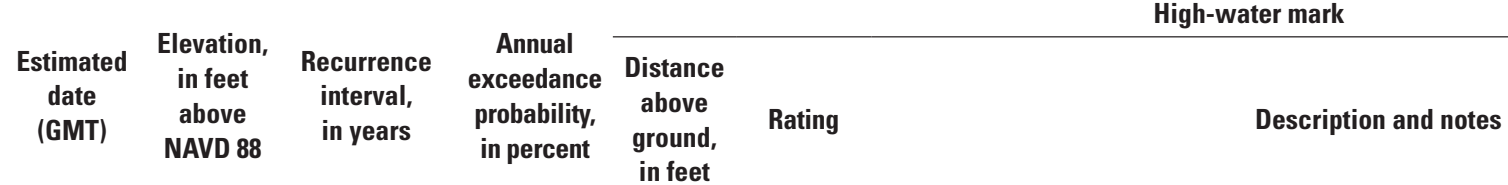

\begin{tabular}{|c|c|c|c|c|c|c|}
\hline $10 / 29 / 2012$ & 6.9 & 30 & 3.3 & 1.7 & Excellent & Excellent seed line on outside of building \\
\hline 10/30/2012 & 6.4 & 30 & 3.3 & 2.7 & Good & Good seed line on outside of garage \\
\hline 10/30/2012 & 6.3 & 60 & 1.7 & 1.3 & Excellent & Excellent seed line on outside of building \\
\hline 10/29/2012 & 6.5 & 50 & 2.0 & 3.7 & Good & Good seed line on side of fence \\
\hline $10 / 29 / 2012$ & 7.5 & $>500$ & $<0.2$ & 3.8 & Good & Good seed line on side of house \\
\hline $10 / 29 / 2012$ & 9.4 & $>500$ & $<0.2$ & 5.6 & Good & Good mud line inside garage \\
\hline $10 / 29 / 2012$ & 8.0 & $<100$ & $>1$ & 3.7 & Excellent & Excellent mud line on outside of house \\
\hline $10 / 29 / 2012$ & 4.2 & $<10$ & $>10$ & 2.3 & Good & Good mud line on fence \\
\hline 10/29/2012 & 6.6 & 30 & 3.3 & 3.7 & Excellent & Excellent seed line on side of house \\
\hline $10 / 30 / 2012$ & 7.9 & 40 & 2.5 & 0.5 & Good & Good mud line on door \\
\hline $10 / 29 / 2012$ & 5.2 & 50 & 2.0 & 1.9 & Excellent & Excellent mud line on concrete wall \\
\hline $10 / 29 / 2012$ & 5.8 & $<500$ & $>0.2$ & 0.0 & Poor & Poor debris line in grass \\
\hline 10/29/2012 & 6.0 & 70 & 1.4 & 2.5 & Good & Good mud line on speed limit sign \\
\hline $10 / 30 / 2012$ & 6.1 & $>100 \&<500$ & $<1 \&>0.2$ & 1.4 & Excellent & Excellent mud line on cinder block wall \\
\hline $10 / 30 / 2012$ & 6.3 & 70 & 1.4 & 0.5 & Excellent & Excellent mud line on fence \\
\hline $10 / 30 / 2012$ & 6.4 & $>100 \&<500$ & $<1 \&>0.2$ & 2.1 & Excellent & Excellent mud line on side of house \\
\hline $10 / 30 / 2012$ & 6.5 & $>100 \&<500$ & $<1 \&>0.2$ & 1.9 & Excellent & Excellent mud line on wooden post \\
\hline $10 / 30 / 2012$ & 6.3 & $<100$ & $>1$ & 1.8 & Excellent & Excellent mud line on post \\
\hline $10 / 30 / 2012$ & 6.5 & $>100 \&<500$ & $<1 \&>0.2$ & 2.4 & Excellent & Excellent seed line on tree \\
\hline $10 / 30 / 2012$ & 6.5 & $>100 \&<500$ & $<1 \&>0.2$ & -- & Excellent & Excellent mud line on gate \\
\hline $10 / 30 / 2012$ & 6.7 & $>100 \&<500$ & $<1 \&>0.2$ & 2.1 & Excellent & Excellent mud line on house \\
\hline 10/29/2012 & 6.5 & $>100 \&<500$ & $<1 \&>0.2$ & 2.1 & Excellent & Excellent seed line on shed \\
\hline $10 / 30 / 2012$ & 6.3 & $>100 \&<500$ & $<1 \&>0.2$ & -- & Good & Good mud line on house \\
\hline $10 / 30 / 2012$ & 8.3 & 60 & 1.7 & 4.5 & Poor & Poor debris line on fence \\
\hline $10 / 30 / 2012$ & 8.5 & $<100$ & $>1$ & 2.8 & Excellent & Excellent seed line on back of shed \\
\hline $10 / 30 / 2012$ & 8.8 & $>100 \&<500$ & $<1 \&>0.2$ & 1.8 & Excellent & Excellent seed line on side of fence \\
\hline $10 / 30 / 2012$ & 8.8 & $>100 \&<500$ & $<1 \&>0.2$ & 1.8 & Excellent & Excellent seed line on outside of building \\
\hline $10 / 30 / 2012$ & 8.6 & 80 & 1.3 & 2.8 & Excellent & Excellent seed line on outside of garage \\
\hline $10 / 30 / 2012$ & 7.8 & 50 & 2.0 & 1.0 & Excellent & Excellent seed line on side of fence \\
\hline $10 / 30 / 2012$ & 8.1 & $>100 \&<500$ & $<1 \&>0.2$ & 1.1 & Excellent & Excellent seed line on basement door of building \\
\hline $10 / 30 / 2012$ & 8.2 & $>100 \&<500$ & $<1 \&>0.2$ & 1.6 & Poor & Poor seed line on back of building \\
\hline $10 / 30 / 2012$ & 7.9 & $>100 \&<500$ & $<1 \&>0.2$ & 0.3 & Poor & Poor seed line on door outside building \\
\hline $10 / 30 / 2012$ & 7.4 & $<500$ & $>0.2$ & 2.2 & Excellent & Excellent seed line on post \\
\hline $10 / 30 / 2012$ & 9.5 & $<100$ & $>1$ & 0.0 & Fair & High-water mark established by Seymour's Boatyard operator \\
\hline 10/29/2012 & 6.1 & $>500$ & $<0.2$ & 2.2 & Excellent & $\begin{array}{l}\text { Excellent seed line inside USGS streamgage— } 01306499 \text {-Connetquot River near North } \\
\text { Great River, NY }\end{array}$ \\
\hline $10 / 29 / 2012$ & 9.9 & $<500$ & $>0.2$ & 0.0 & Good & Good wash line on grass lawn \\
\hline $10 / 29 / 2012$ & 9.5 & $<100$ & $>1$ & 2.4 & Fair & Fair debris line on tree \\
\hline 10/29/2012 & 9.6 & $>100 \&<500$ & $<1 \&>0.2$ & 0.0 & Good & Good debris line \\
\hline $10 / 29 / 2012$ & 9.8 & $>100 \&<500$ & $<1 \&>0.2$ & 3.4 & Good & Good seed line on fence \\
\hline $10 / 29 / 2012$ & 9.6 & $>100 \&<500$ & $<1 \&>0.2$ & 1.4 & Excellent & Excellent seed line on outside of building \\
\hline 10/30/2012 & 9.8 & $>100 \&<500$ & $<1 \&>0.2$ & 2.5 & Excellent & Excellent seed line on outside of building \\
\hline $10 / 30 / 2012$ & 10.0 & $>100 \&<500$ & $<1 \&>0.2$ & 1.8 & Good & Good seed line on outside of shed \\
\hline 10/29/2012 & 7.9 & 40 & 2.5 & 0.8 & Good & Good seed line on mailbox post \\
\hline 10/29/2012 & 8.9 & $>100 \&<500$ & $<1 \&>0.2$ & 1.9 & Excellent & Excellent seed line on side of fence \\
\hline 10/29/2012 & 9.2 & $>100 \&<500$ & $<1 \&>0.2$ & 1.7 & Excellent & Excellent seed line on side of fence \\
\hline
\end{tabular}


Table 7. Peak storm-tide elevations produced by Hurricane Sandy at 346 high-water-mark sites, and the corresponding Federal Emergency recurrence intervals) in New York.-Continued

[High-water-mark site locations are shown in figure 2. FEMA, Federal Emergency Management Agency; NAVD 88, North American Vertical Datum of 1988; no, number;

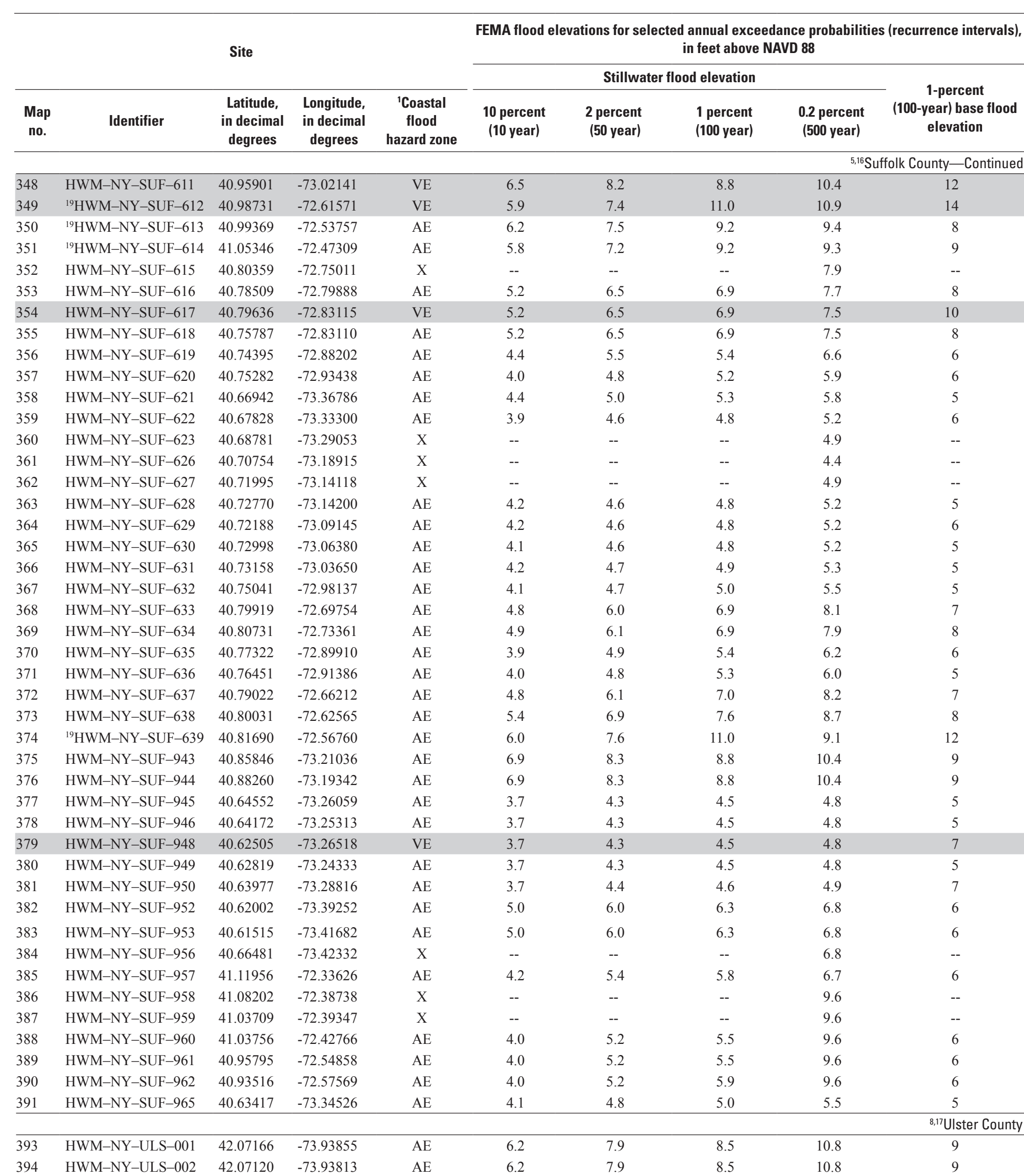

Management Agency flood elevations for the 10-, 2-, 1-, and 0.2-percent annual exceedance probabilities (10-, 50-, 100-, and 500-year

GMT, Grenwich Mean Time; $<$ less than; $>$, greater than; \&, and; --, no value; USGS, U.S. Geological Survey

\section{Hurricane Sandy peak storm tide}

High-water mark

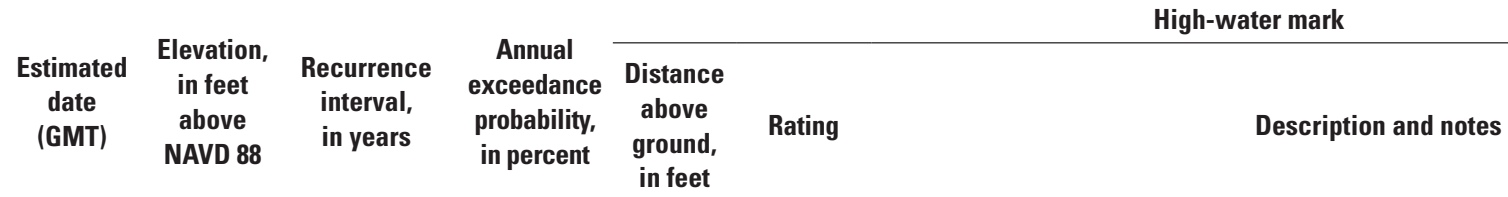

$\begin{array}{lllllll}10 / 29 / 2012 & 8.6 & <100 & >1 & 3.4 & \text { Excellent } & \text { Excellent seed line on utility pole } \\ 10 / 29 / 2012 & 7.3 & <100 & >1 & 1.3 & \text { Excellent } & \text { Excellent seed line on guard booth }\end{array}$

$\begin{array}{lllllll}10 / 29 / 2012 & 8.8 & 90 & 1.1 & 1.4 & \text { Excellent } & \text { Excellent seed line on side of house } \\ 10.52012 & 7.7 & 60 & 1.7 & 2.5 & \text { Exellent } & \text { Ecellent }\end{array}$

$\begin{array}{lllllll}10 / 29 / 2012 & 7.7 & 60 & 1.7 & 2.5 & \text { Excellent } & \text { Excellent seed line on mailbox pos }\end{array}$

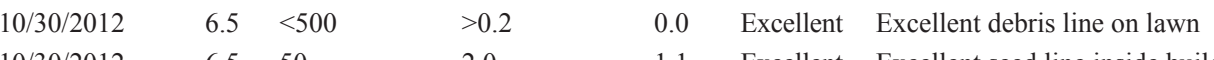

$\begin{array}{lllllll}10 / 30 / 2012 & 6.5 & 50 & 2.0 & 1.1 & \text { Excellent Excellent seed line inside building }\end{array}$

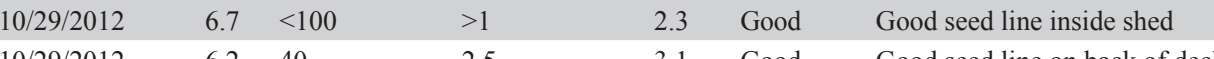

$\begin{array}{lllllll}10 / 29 / 2012 & 6.2 & 40 & 2.5 & 3.1 & \text { Good } & \text { Good seed line on back of deck } \\ 10 / 29 / 2012 & 4.8 & 20 & 5.0 & 2.1 & \text { Good } & \text { Good seed line on side of fence }\end{array}$

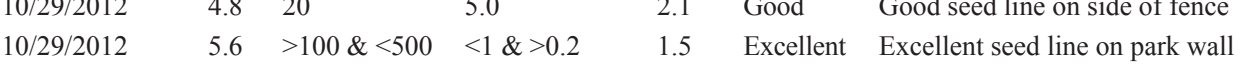

$\begin{array}{lllllll}10 / 29 / 2012 & 5.6 & >100 \&<500 & <1 \&>0.2 & 1.5 & \text { Excellent } & \text { Excellent seed line on park wiall } \\ 10.8 & <0.2 & 2.8 & \text { Excellent } & \text { Excellent seed line on building }\end{array}$

$\begin{array}{lllllll}10 / 29 / 2012 & 6.6 & >500 & <0.2 & 1.8 & \text { Excellent Excellent mud line on fence }\end{array}$

$\begin{array}{lllllll}10 / 29 / 2012 & 6.2 & >500 & <0.2 & 0.0 & \text { Good } & \text { Good debris line }\end{array}$

$\begin{array}{lllllll}10 / 29 / 2012 & 5.7 & >500 & <0.2 & 0.0 & \text { Good } & \text { Good debris line }\end{array}$

$\begin{array}{lllllll}10 / 29 / 2012 & 5.5 & >500 & <0.2 & 0.0 & \text { Good } & \text { Good debris line on grass }\end{array}$

$\begin{array}{llllll}10 / 29 / 2012 & 5.8 & >500 & <0.2 & 2.1 & \text { Excellent } \\ & \text { Excellent seed line on fence }\end{array}$

\begin{tabular}{llllll}
$10 / 29 / 2012$ & 5.4 & $>500$ & $<0.2$ & 1.9 & Excellent \\
\hline
\end{tabular}

\begin{tabular}{llllll}
$10 / 29 / 2012$ & 5.5 & $>500$ & $<0.2$ & 1.2 & Excellent \\
\hline
\end{tabular}

$\begin{array}{lllllll}10 / 29 / 2012 & 5.6 & >500 & <0.2 & 3.1 & \text { Excellent } & \text { Excellent seed line on fence }\end{array}$

10/29/2012 $\quad 5.4 \quad>100 \&<500 \quad<1 \&>0.2 \quad 1.4 \quad$ Excellent Excellent mud line on fence

$\begin{array}{lllllll}10 / 29 / 2012 & 5.9 & 50 & 2.0 & 2.4 & \text { Good } & \text { Good seed line on fence } \\ 1029 / 2012 & 6.5 & 80 & 1.3 & 0.0 & \text { Good }\end{array}$

$\begin{array}{llllllll}10 / 29 / 2012 & 6.5 & 80 & 1.3 & 0.0 & \text { Good } & \text { Good wash line in front yard } \\ 10292012 & 5.2 & 80 & 1.3 & 1.4 & \text { Exellent Excllest }\end{array}$

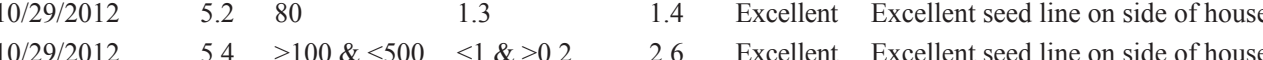

$\begin{array}{llllllll}10 / 29 / 2012 & 6.4 & 70 & 1.4 & 1.4 & \text { Excellent } & \text { Excellent seed line on fence }\end{array}$

$\begin{array}{lllllll}10 / 29 / 2012 & 3.5 & <10 & >10 & 1.0 & \text { Excellent } & \text { Excellent seed line on side of force }\end{array}$

$\begin{array}{lllllll}10 / 29 / 2012 & 6.4 & 20 & 5.0 & 0.5 & \text { Excellent Excellent seed line on fence }\end{array}$

$\begin{array}{llllll}8.6 & 80 & 1.3 & 0.6 & \text { Good } & \text { Good seed line on fence }\end{array}$

$\begin{array}{lllllll}10 / 29 / 2012 & 8.9 & >100 \&<500 & <1 \&>0.2 & 2.8 & \text { Excellent } & \text { Excellent seed line on door of hous }\end{array}$

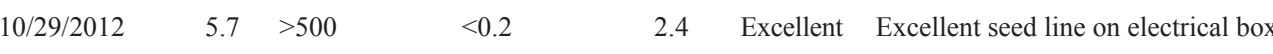

$\begin{array}{lllllll}10 / 29 / 2012 & 6.4 & <100 & >1 & 1.4 & \text { Excellent } & \text { Excellent seed line on inside wall of building }\end{array}$

$\begin{array}{llllll}10 / 29 / 2012 & 5.6 & >500 & <0.2 & 0.0 & \text { Poor } \quad \text { Poor debris line on path }\end{array}$

$\begin{array}{lllllll}10 / 29 / 2012 & 7.8 & >500 & <0.2 & 5.5 & \text { Excellent } & \text { Excellent seed line on post under back deck }\end{array}$

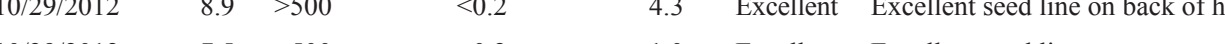

$\begin{array}{lllllll}10 / 29 / 2012 & 7.5 & >500 & <0.2 & 1.0 & \text { Excellent } & \text { Excellent seed line on garage } \\ 10292012 & 7.5 & >500 & <0.2 & 1.0 & \text { Excellent } & \text { Excellent seed line on side }\end{array}$

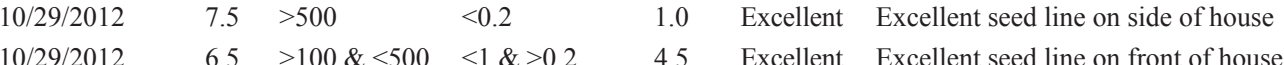

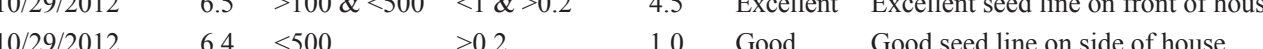

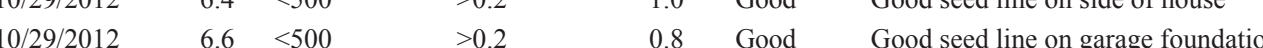

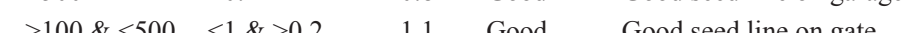

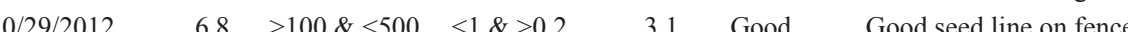

$\begin{array}{llllll}10 / 29 / 2012 & 7.8 & >100 \&<500 & <1 \&>0.2 & 2.6 & \text { Good } \quad \text { Good mud line on shed }\end{array}$

$\begin{array}{llllll}10 / 29 / 2012 & 5.2 & >100 \&<500 & <1 \&>0.2 & 0.8 & \text { Excellent } \quad \text { Excellent seed line on door inside maintenance garage }\end{array}$

10/30/2012 $\quad 9.4 \quad>100 \&<500 \quad<1 \&>0.2 \quad 3.0 \quad$ Good $\quad$ Good seed line on back of shed behind 145 Lighthouse Driv

10/30/2012 $\quad 9.4>100 \&<500 \quad<1 \&>0.2 \quad 4.3 \quad$ Good $\quad$ Good seed line on landward side of 146 Lighthouse drive 
Table 7. Peak storm-tide elevations produced by Hurricane Sandy at 346 high-water-mark sites, and the corresponding Federal Emergency recurrence intervals) in New York.-Continued

[High-water-mark site locations are shown in figure 2. FEMA, Federal Emergency Management Agency; NAVD 88, North American Vertical Datum of 1988; no., number;

\begin{tabular}{cccccccccccc}
\hline & & & & & \multicolumn{3}{c}{ FEMA flood elevations for selected annual exceedance probabilities (recurrence intervals), } \\
in feet above NAVD 88
\end{tabular}

'High-water marks (HWMs) from sites in VE zones (shaded gray) are likely to have been affected by wave heights of 3 feet (ft) or greater and, therefore, are comparable only to the base flood deations; HWMs from sites in other cor

2Stillwater flood elevations converted from units of feet above the National Geodetic Vertical Datum of 1929 (NGVD 29) as reported in Federal Emergency

${ }^{3}$ Coastal flood hazard zones from Federal Emergency Management Agency (2013); base flood elevations converted from units of feet above NGVD 29 as reported in

${ }^{4}$ Stillwater flood elevations from Federal Emergency Management Agency (2012)

'Coastal flood hazard zones and base flood elevations from Federal Emergency Management Agency (2013b)

¿Stillwater flood elevations from Federal Emergency Management Agency (2008).

Stillwater flood elevations from Federal Emergency Management Agency (2009a).

${ }^{8}$ Coastal flood hazard zones and base flood elevations from Federal Emergency Management Agency (2013c).

'Stillwater flood elevations converted from units of feet above NGVD 29 as reported in Federal Emergency Management Agency (2007a).

${ }^{10}$ Coastal flood hazard zones from Federal Emergency Management Agency (2013b); base flood elevations converted from units of feet above NGVD 29 as reported
Management Agency flood elevations for the 10-, 2-, 1-, and 0.2-percent annual exceedance probabilities (10-, 50-, 100-, and 500-year

GMT, Grenwich Mean Time; < less than; >, greater than; \&, and; --, no value; USGS, U.S. Geological Survey

\section{Hurricane Sandy peak storm tide}

\begin{tabular}{|c|c|c|c|c|c|c|}
\hline & & \multirow[b]{3}{*}{$\begin{array}{l}\text { Recurrence } \\
\text { interval, } \\
\text { in years }\end{array}$} & \multirow[b]{3}{*}{$\begin{array}{c}\text { Annual } \\
\text { exceedance } \\
\text { probability, } \\
\text { in percent }\end{array}$} & \multirow{2}{*}{\multicolumn{3}{|c|}{ High-water mark }} \\
\hline \multirow[b]{2}{*}{$\begin{array}{l}\text { Estimated } \\
\text { date } \\
\text { (GMT) }\end{array}$} & \multirow[b]{2}{*}{$\begin{array}{c}\text { Elevation, } \\
\text { in feet } \\
\text { above } \\
\text { NAVD } 88\end{array}$} & & & & & \\
\hline & & & & $\begin{array}{l}\text { Distance } \\
\text { above } \\
\text { ground, } \\
\text { in feet }\end{array}$ & Rating & Description and notes \\
\hline 10/30/2012 & 9.4 & $>100 \&<500$ & $<1 \&>0.2$ & 3.8 & Good & Good seed line on handrail of U.S. Coast Guard post \\
\hline 10/30/2012 & 9.3 & $>100 \&<500$ & $<1 \&>0.2$ & 4.9 & Excellent & Excellent seed line on large front window of 136 Delaware Avenue \\
\hline 10/30/2012 & 9.3 & $>100 \&<500$ & $<1 \&>0.2$ & 4.0 & Excellent & Excellent seed line on siding of south side of 138 Delaware Avenue \\
\hline 10/30/2012 & 9.2 & $>100 \&<500$ & $<1 \&>0.2$ & 3.1 & Excellent & Excellent seed line on west side of 138 Delaware Avenue \\
\hline $10 / 30 / 2012$ & 9.2 & $>100 \&<500$ & $<1 \&>0.2$ & 1.5 & Excellent & Excellent mud line on south side of 146 Delaware Avenue \\
\hline $10 / 30 / 2012$ & 9.0 & $>500$ & $<0.2$ & 0.0 & Good & Good debris line on grass downstream of Metro North station \\
\hline 10/30/2012 & 9.0 & $>500$ & $<0.2$ & 2.4 & Excellent & Excellent seed line inside public bathroom \\
\hline 10/30/2012 & 8.9 & $>500$ & $<0.2$ & 1.9 & Excellent & Excellent seed line on upstream side of "Harvest-on-Hudson" restauran \\
\hline 10/30/2012 & 9.0 & $>500$ & $<0.2$ & 0.0 & Good & Good debris line on grass on upstream side of Hudson Park at end of Wells Avenue \\
\hline 10/30/2012 & 9.0 & $>500$ & $<0.2$ & 0.0 & Good & Good debris line on grass on upstream side of Hudson Park at end of Wells Avenue \\
\hline 10/30/2012 & 9.2 & $>500$ & $<0.2$ & 1.1 & Fair & Fair seed line on exterior of door on streamward side of 2 Alexander Street \\
\hline 10/30/2012 & 10.5 & $<100$ & $>1$ & 2.7 & Excellent & Excellent seed line in shower stall of Mamaroneck Yacht Club \\
\hline 10/30/2012 & 10.2 & 40 & 2.5 & 3.1 & Excellent & Excellent seed line inside steel container on dock \\
\hline $10 / 30 / 2012$ & 11.8 & $<500$ & $>0.2$ & 0.0 & Good & Good debris line on grass hill \\
\hline 10/30/2012 & 10.1 & 40 & 2.5 & 0.0 & Good & Good debris line on grass berm \\
\hline 10/30/2012 & 10.2 & 30 & 3.3 & 2.5 & Excellent & Excellent seed line on wall of utility house \\
\hline $10 / 30 / 2012$ & 9.8 & 30 & 3.3 & 30 & Excellent & Excellent seed line on wall inside building \\
\hline 10/30/2012 & 10.3 & 40 & 2.5 & 0.3 & Good & Good seed line on inside of concrete water supply \\
\hline
\end{tabular}

"Results not discussed in text or shown in figures.

"Coastal flood hazard zones and flood elevations from Federal Emergency Management Agency (2013e).

"Stillwater flood elevations from Federal Emergency Management Agency (2009b).

"Stillwater flood elevations converted from units of feet above NGVD 29 as reported in Federal Emergency Management Agency (1984).

"SStillwater flood elevations converted from units of feet above NGVD 29 as reported in Federal Emergency Management Agency (1981a, 1981b).

íStillwater flood elevations from Federal Emergency Management Agency (2009c).

"Stillwater flood elevations from Federal Emergency Management Agency (2011)

${ }^{18}$ Stillwater flood elevations from Federal Emergency Management Agency (2007b).

"Stillwater flood elevation for 1-percent annual exceedance probability (100-year recurrence interval) includes wave setup.

${ }^{20} \mathrm{High}-\mathrm{water}$ mark HWM-NY-REN-001 published previously as HWM-NY-COL-001.

${ }^{21}$ High-water mark HWM-NY-REN-003 published previously as HWM-NY-COL-003.

2 High-water mark HWM-NY-REN-004 published previously as HWM-NY-COL-004. 



\section{Glossary}

\section{Annual exceedance probability (AEP)}

flood The 1-percent AEP flood has a 1 in 100 chance of being equaled or exceeded in any 1 year, and it has an average recurrence interval of 100 years (see Holmes and Dinicola, 2010). The 0.2-percent AEP flood has a 0.2 in 100 chance of being equaled or exceeded in any 1 year, and it has an average recurrence interval of 500 years.

Base flood elevation The elevation shown on the flood insurance rate map (FIRM) for zones $\mathrm{AE}, \mathrm{AH}, \mathrm{A} 1-30$, or $\mathrm{VE}$ that indicates the water surface elevation resulting from a flood that has a 1-percent chance of occurring in any given year. In coastal areas, BFEs are calculated using four components: (1) the storm surge stillwater elevation, (2) the amount of wave setup, (3) the wave height above the storm surge stillwater elevation, and (4) the wave runup above the storm surge stillwater elevation (where present).

Flood hazard zone Flood hazard zones are lettered based on the level and type of flood risk:

Zone VE The area subject to high velocity wave action (a 3-foot breaking wave) from the 1-percent annual chance coastal flood.

Zone A/AE The area subject to inundation from the 1-percent annual chance flood.

These areas are not subject to high velocity wave action but are still considered high risk flooding areas.

Zone X Areas of moderate coastal flood risk outside the regulatory 1-percent annual chance flood up to the 0.2-percent annual chance flood level.
Nor'easter Northeastern coastal storm.

Stillwater elevation The projected elevation of floodwaters in the absence of waves resulting from wind or seismic effects. In coastal areas, stillwater elevations are determined when modeling coastal storm surge; the results of overland wave modeling are used in conjunction with the stillwater elevations to develop the coastal base flood elevations.

Storm surge Water-level rise caused by a storm over and above the predicted astronomical tide.

Storm tide Water-level rise due to the combination of storm surge and the astronomical tide.

Streamgage Instrumentation used to measure water level and corresponding streamflow.

Tide gage Instrumentation used to measure coastal water level.

Wave runup The rush of water that extends inland when waves come ashore. Wave runup effects are computed as a part of the overland wave analysis and are added to the stillwater elevations computed from the storm surge model.

Wave setup The increase in the water level caused by the onshore mass transport of water that occurs due to waves breaking during a storm. Wave setup is affected by the wave height, the speed at which waves approach shore, and the nearshore slope. 
For additional information write to: Director, New York Water Science Center U.S. Geological Survey

2045 Route 112, Building 4

Coram, NY 11727

Information requests:

(518) 285-5602

or visit our Web site at:

http://ny.water.usgs.gov

Publishing support by:

The Pembroke and West Trenton Publishing Service Centers. 


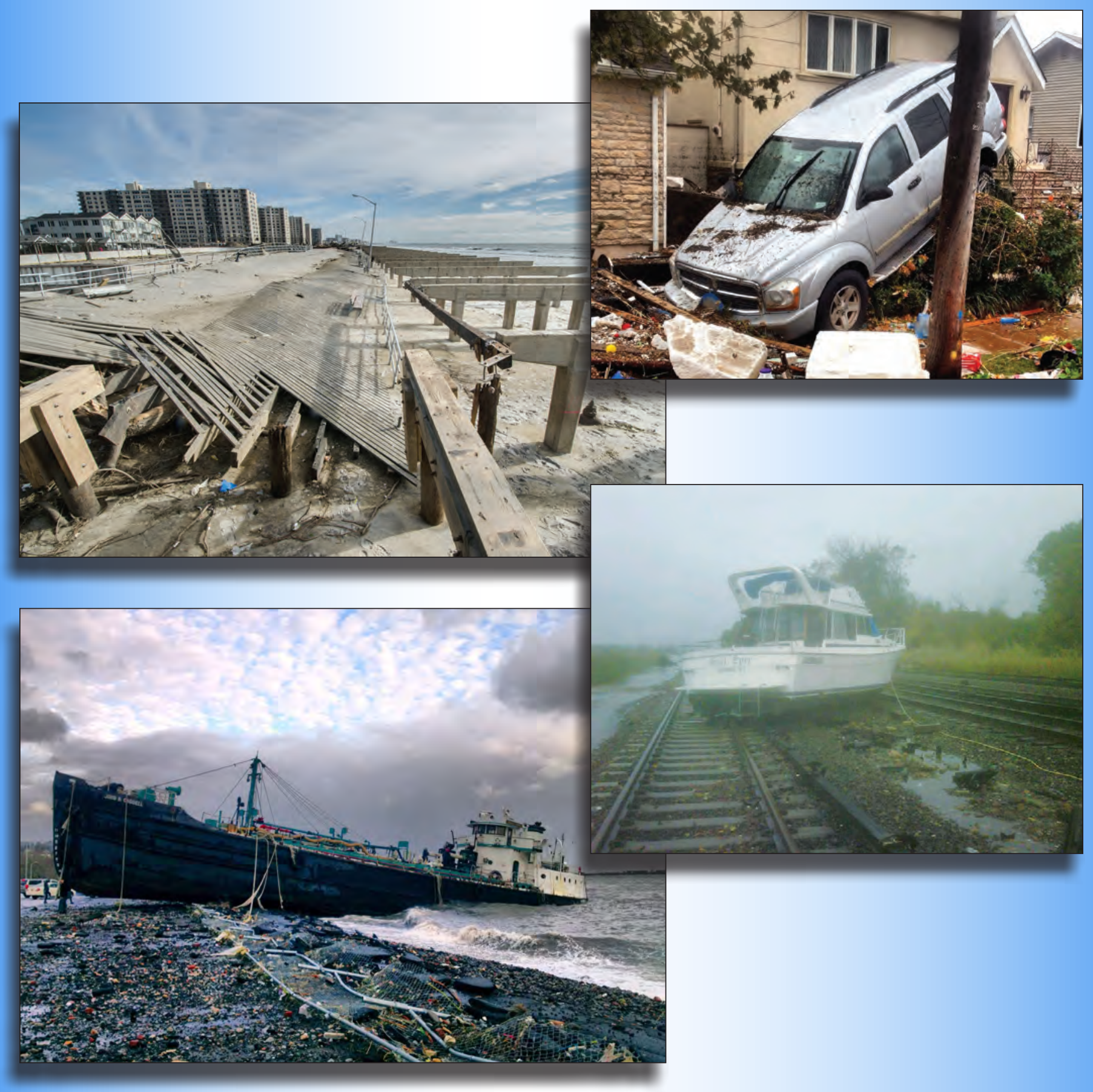

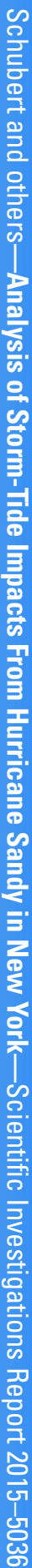

